OPEN ACCESS

Edited by: Alessandro Leone, University of Milan, Italy

Reviewed by: Ramkumar Mohan University of Michigan, United States

Simona Bertoli, University of Milan, Italy

${ }^{*}$ Correspondence: Jacqueline M. Stephens jsteph1@/su.edu

Specialty section: This article was submitted to Diabetes: Molecular Mechanisms,

a section of the journal

Frontiers in Endocrinology

Received: 17 June 2021 Accepted: 16 December 2021 Published: 08 February 2022

Citation:

Boudreau A, Richard AJ, Harvey I and Stephens JM (2022) Artemisia scoparia and Metabolic Health Untapped Potential of an Ancient Remedy for Modern Use.

Front. Endocrinol. 12:727061. doi: 10.3389/fendo.2021.727061

\section{Artemisia scoparia and Metabolic Health: Untapped Potential of an Ancient Remedy for Modern Use}

\author{
Anik Boudreau ${ }^{1}$, Allison J. Richard ${ }^{1}$, Innocence Harvey ${ }^{1}$ and Jacqueline M. Stephens ${ }^{1,2 *}$ \\ ${ }^{1}$ Adipocyte Biology Laboratory, Pennington Biomedical Research Center, Baton Rouge, LA, United States, ${ }^{2}$ Department of \\ Biological Sciences, Louisiana State University, Baton Rouge, LA, United States
}

Botanicals have a long history of medicinal use for a multitude of ailments, and many modern pharmaceuticals were originally isolated from plants or derived from phytochemicals. Among these, artemisinin, first isolated from Artemisia annua, is the foundation for standard anti-malarial therapies. Plants of the genus Artemisia are among the most common herbal remedies across Asia and Central Europe. The species Artemisia scoparia (SCOPA) is widely used in traditional folk medicine for various liver diseases and inflammatory conditions, as well as for infections, fever, pain, cancer, and diabetes. Modern in vivo and in vitro studies have now investigated SCOPA's effects on these pathologies and its ability to mitigate hepatotoxicity, oxidative stress, obesity, diabetes, and other disease states. This review focuses on the effects of SCOPA that are particularly relevant to metabolic health. Indeed, in recent years, an ethanolic extract of SCOPA has been shown to enhance differentiation of cultured adipocytes and to share some properties of thiazolidinediones (TZDs), a class of insulin-sensitizing agonists of the adipogenic transcription factor PPAR $\gamma$. In a mouse model of diet-induced obesity, SCOPA diet supplementation lowered fasting insulin and glucose levels, while inducing metabolically favorable changes in adipose tissue and liver. These observations are consistent with many lines of evidence from various tissues and cell types known to contribute to metabolic homeostasis, including immune cells, hepatocytes, and pancreatic beta-cells. Compounds belonging to several classes of phytochemicals have been implicated in these effects, and we provide an overview of these bioactives. The ongoing global epidemics of obesity and metabolic disease clearly require novel therapeutic approaches. While the mechanisms involved in SCOPA's effects on metabolic, anti-inflammatory, and oxidative stress pathways are not fully characterized, current data support further investigation of this plant and its bioactives as potential therapeutic agents in obesity-related metabolic dysfunction and many other conditions. 


\section{INTRODUCTION}

Rising obesity rates around the globe are driving an epidemic of metabolic syndrome (MS) and type 2 diabetes (T2DM), and novel therapeutic interventions are needed. Because the pathogenesis of obesity-related metabolic dysfunction is multifactorial and complex, diverse strategies have been employed to hinder its development and manifestations, namely stimulating insulin production in pancreatic beta-cells, inhibiting hepatic glucose output, reducing glucose reabsorption in the kidney, and enhancing peripheral glucose uptake and insulin sensitivity (1). The molecular mechanisms driving these effects include inhibition of ATP-sensitive potassium channels in pancreatic beta-cells to stimulate insulin release, activation of the glucagon-like peptide-1 (GLP-1) receptor or inhibition of dipeptidyl peptidase-4 activity to enhance incretin signaling and lower circulating glucose levels, and activation of the peroxisome proliferator-activated receptorgamma (PPAR $\gamma)$ in adipocytes to improve insulin sensitivity in peripheral tissues (2-5). Type 1 diabetes (T1DM), which represents only about five percent of diabetes mellitus cases, results from the progressive destruction of pancreatic beta-cells and consequent inability to produce insulin. Therefore, interventions to improve insulin sensitivity are ineffective for T1DM, and insulin replacement is currently the only glucoselowering pharmacological treatment available (6). In addition to strategies for controlling glycemia, treatment of both T1DM and T2DM also includes management of diabetic complications such as kidney disease, cardiovascular disease, and retinopathy.

The first-line medication for T2DM, metformin, is a synthetic derivative of the phytochemical galegine, first isolated from Galega officinalis. This plant, also known as French lilac or goat's rue, was used medicinally in medieval Europe for many ailments, including symptoms that are now attributed to T2DM (7). Metformin reduces hepatic glucose production via mechanisms that have not been fully elucidated. While it is known that metformin activates adenosine monophosphate (AMP)-activated protein kinase (AMPK) in the liver, there is evidence that several AMPK-independent mechanisms are likely to be involved in its metabolic impacts $(4,8)$. These include inhibition of mitochondrial respiration and of the gluconeogenic pathway (8-12). In addition, metformin's glucose-lowering activity may be partially mediated through effects on the gut (13-15). Therefore, although metformin has been used clinically for over half a century, there is still significant debate around its precise mechanisms of action.

Across the world, plants have been used medicinally for centuries, and many pharmaceuticals are derived from natural products. Even now, factors such as availability, cost, or cultural practices drive the continued use of botanical products as supplements or alternatives to pharmaceuticals. Although rigorous and thorough investigation is often lacking, many plants are currently being screened or studied both in vitro and in vivo to assess their bioactivities and efficacy. One such plant, Artemisia scoparia (SCOPA), has a long history of medicinal use in much of Asia and Central Europe to treat liver diseases, inflammatory conditions, and diabetes, among other ailments. The genus Artemisia comprises hundreds of species, some of which are among the most widely used medicinal plants across the world $(1,2)$. Perhaps the best known product of the genus is the anti-malarial drug artemisinin, whose isolation from Artemisia annua was awarded the Nobel Prize for Physiology or Medicine in 2015 (3). Other medicinal species include A. capillaris, A. absinthum, A. argyi, A. capillaris and A. dracunculus, but there are many more (4-6). Modern studies have now established that extracts from SCOPA exert a wide range of effects in many cell types and animal models. In addition, many individual bioactive compounds responsible for these effects have been identified. This review describes the traditional folk medicine uses of SCOPA and examines what is currently known about its effects in various animal models and cell types, with a focus on findings relevant to metabolic health. We also discuss individual compounds in SCOPA and their wide range of effects, including the potential to attenuate metabolic dysfunction, particularly in the context of diet-induced obesity. Although SCOPA has not been studied in T1DM, some of its reported actions suggest that it may mitigate diabetic complications in addition to improving glycemic control. Such effects could be beneficial in T1DM as well as T2DM.

Even in the absence of a fully elucidated mechanism of action, identifying additional agents, like metformin, from natural products with therapeutic potential against metabolic dysfunction is of great value in fighting the growing epidemics of obesity, MS, and T2DM. Thus, an overarching goal of this review is to compile and evaluate anecdotal and mechanistic studies of $A$. scoparia's ability to modulate metabolic function. We also aim to demonstrate the potential of bioactives from $A$. scoparia for modern clinical and/or complementary use to support metabolic health, while highlighting the significant need for additional studies to evaluate mechanism(s) of action on a molecular level.

\section{ETHNOPHARMACOLOGY AND TRADITIONAL MEDICINAL USES OF A. SCOPARIA}

SCOPA is one of the most widely used medicinal plants across many parts of Asia, and modern ethnobotany studies have documented its many indications in Afghanistan, Pakistan, Saudi Arabia, Iran, and China for conditions such as liver, gallbladder, and digestive disorders; various infectious and inflammatory diseases; ear pain; cardiovascular conditions; and diabetes and hyperglycemia (7-33). One example of the ethnopharmacological documentation of SCOPA is a study conducted in the Upper Neelum Valley of Pakistan, in which data collected from interviews were analyzed and individual plants or medicinal indications were assigned quantitative ethnobotanical indices. SCOPA was determined to have a high use value in this population (21). Reported indications and formulations for SCOPA in traditional folk medicine are shown in Table 1 and Figure 1. It is notable that many of these are common to distinct populations in diverse regions.

SCOPA is very prominent in Traditional Chinese Medicine (TCM), particularly for its hepatoprotective and choleretic effects. 
TABLE 1 | Documented indications and geographic locations for traditional uses of $A$. scoparia.

\begin{tabular}{|c|c|c|c|c|c|}
\hline Medicinal Use & Region & Plant Part & Formulation & ROA $^{\mathrm{b}}$ & Ref(s) \\
\hline \multirow[t]{5}{*}{ Diabetes/ Hyperglycemia } & Pakistan/Afghanistan border & Root & Decoction & Oral & $(10)$ \\
\hline & Lower Kurram, Pakistan & Root & & & $(28)$ \\
\hline & Zhejiang Province, China & Root & Infusion & Oral & (23) \\
\hline & Uttarakhand, India & Leaves & Powder & Oral & (34) \\
\hline & Shigar Valley, Pakistan & Leaves & Infusion & Oral & $(32)$ \\
\hline Cancer & $\begin{array}{l}\text { Pakistan/Afghanistan border } \\
\text { China }\end{array}$ & Root & Decoction & Oral & $\begin{array}{l}(10) \\
(35)^{\mathrm{a}}\end{array}$ \\
\hline \multirow[t]{5}{*}{$\begin{array}{l}\text { Hepatitis, jaundice, liver or gallbladder } \\
\text { disease }\end{array}$} & $\begin{array}{l}\text { Neelum Valley, Pakistan } \\
\text { China }\end{array}$ & Leaves & Infusion & Oral & $\begin{array}{l}(21) \\
(35)^{\mathrm{a}}\end{array}$ \\
\hline & China & Aerial parts & Decoction & Oral & $(36)$ \\
\hline & Pakistan/Afghanistan border & Root & Decoction & Oral & $(10)$ \\
\hline & Onaizah Province, Saudi Arabia & Whole plant & Decoction & Oral & $(37)$ \\
\hline & Zhejiang Province, China & Flowers & Decoction & Oral & $(23)$ \\
\hline \multirow[t]{12}{*}{ Digestion } & Neelum Valley, Pakistan & Leaves & Infusion & Oral & $(21)$ \\
\hline & Hormozgan Province, Iran & Leaves & Decoction & Oral & $(25)$ \\
\hline & Ilam Province, Iran & Flowers & & Internal & $(16)$ \\
\hline & China & & & & $(38)$ \\
\hline & Pakistan & & & & (39) \\
\hline & Samahni Valley, Pakistan & Leaves, roots & Juice, Decoction & Oral & $(27)$ \\
\hline & Onaizah Province, Saudi Arabia & Whole Plant & Decoction & Oral & $(37)$ \\
\hline & Zhejiang Province, China & Root & Infusion & Oral & $(23)$ \\
\hline & Swat District, Pakistan & Young shoots & & & (19) \\
\hline & Spiti Valley, Western Himalaya, India & & & & (20) \\
\hline & Uttarakhand, India & Leaves & Powder & Oral & (34) \\
\hline & Gujranwala District, Pakistan & Whole plant & Powder, roasted & Oral & (13) \\
\hline \multirow[t]{5}{*}{ ENT/Dental } & Pakistan & & & Topical & $(26,39)$ \\
\hline & Ilam Province Iran (Kurd tribe) & Flowers & & Internal & $(16)$ \\
\hline & Samahni Valley, Pakistan & Leaves, roots & Juice, decoction & Topical & $(27)$ \\
\hline & Onaizah Province, Saudi Arabia & Whole plant & Decoction & Ear drops & $(37)$ \\
\hline & Spiti Valley, Western Himalaya, India & Leaves, seeds & Poultice & Topical & (20) \\
\hline \multirow[t]{4}{*}{ Depurative "blood purification" } & Lower Kurram, Pakistan & Roots & Decoction & Oral & $(28)$ \\
\hline & Pakistan & & Infusion & Oral & $(26,39)$ \\
\hline & Samahni Valley, Pakistan & Leaves, roots & Juice, decoction & Oral & (27) \\
\hline & Uttarakhand, India & Leaves & Powder & Oral & (34) \\
\hline Fever, microbial or parasitic & Pakistan & & & & (39) \\
\hline \multirow[t]{8}{*}{ infections, snake or scorpion venom } & China & & & & $(38)$ \\
\hline & Pakistan & Whole plant & & & $(40)$ \\
\hline & Zhejiang Province, China & Leaves & Decoction & Oral & (23) \\
\hline & Swat District, Pakistan & Whole plant & Decoction & Oral & $(17)$ \\
\hline & Swat District, Pakistan & Young shoots & & & (19) \\
\hline & Uttarakhand, India & Leaves & Powder, roasted & Oral & (34) \\
\hline & Gujranwala District, Pakistan & Leaves & & Topical & $(13)$ \\
\hline & Gujranwala District, Pakistan & Flowers, shoots & Decoction & Oral & (13) \\
\hline \multirow[t]{5}{*}{ Burns/wounds/skin/hair } & Pakistan & Twigs & Smoke & External & $(26,39)$ \\
\hline & Ilam Province, Iran & Flowers & & Internal & $(16)$ \\
\hline & Spiti Valley, India & & Smoke & External & $(20)$ \\
\hline & Uttarakhand, India & Leaves & Paste & Topical & $(34)$ \\
\hline & Gujranwala District, Pakistan & Leaves & Extract+oil, boiled & Topical & $(13)$ \\
\hline \multirow[t]{4}{*}{ Cardiovascular } & Pakistan & Whole plant & & & $(40)$ \\
\hline & China & & & & (38) \\
\hline & Onaizah Province, Saudi Arabia & Whole plant & Decoction & Oral & $(37)$ \\
\hline & Zhejiang Province, China & Roots & Infusion & Oral & (23) \\
\hline \multirow[t]{4}{*}{ Respiratory } & Pakistan & & & & (39) \\
\hline & Pakistan & Whole plant & & & $(40)$ \\
\hline & Zhejiang Province, China & Leaves & Decoction & Oral & (23) \\
\hline & Uttarakhand, India & Leaves & Powder, roasted & Oral & (34) \\
\hline
\end{tabular}

${ }^{a}$ Yinchen - refers to $A$. scoparia or A. capillaris.

${ }^{b} R O A$, Route of Administration.

Its uses are extensively described in the canon of TCM literature (41-44) and cited in the current Chinese Pharmacopoeia (35). "Artemisia scopariae herba" (ASH), or "Yinchen", refers to the dried aerial parts of SCOPA or of its close relative, Artemisia capillaris, with the two plants being used interchangeably for its preparation. A decoction of Yinchen is the principal constituent of many TCM formulae, in which ASH is combined with other herbal products. Importantly, a distinction is made between ASH from 


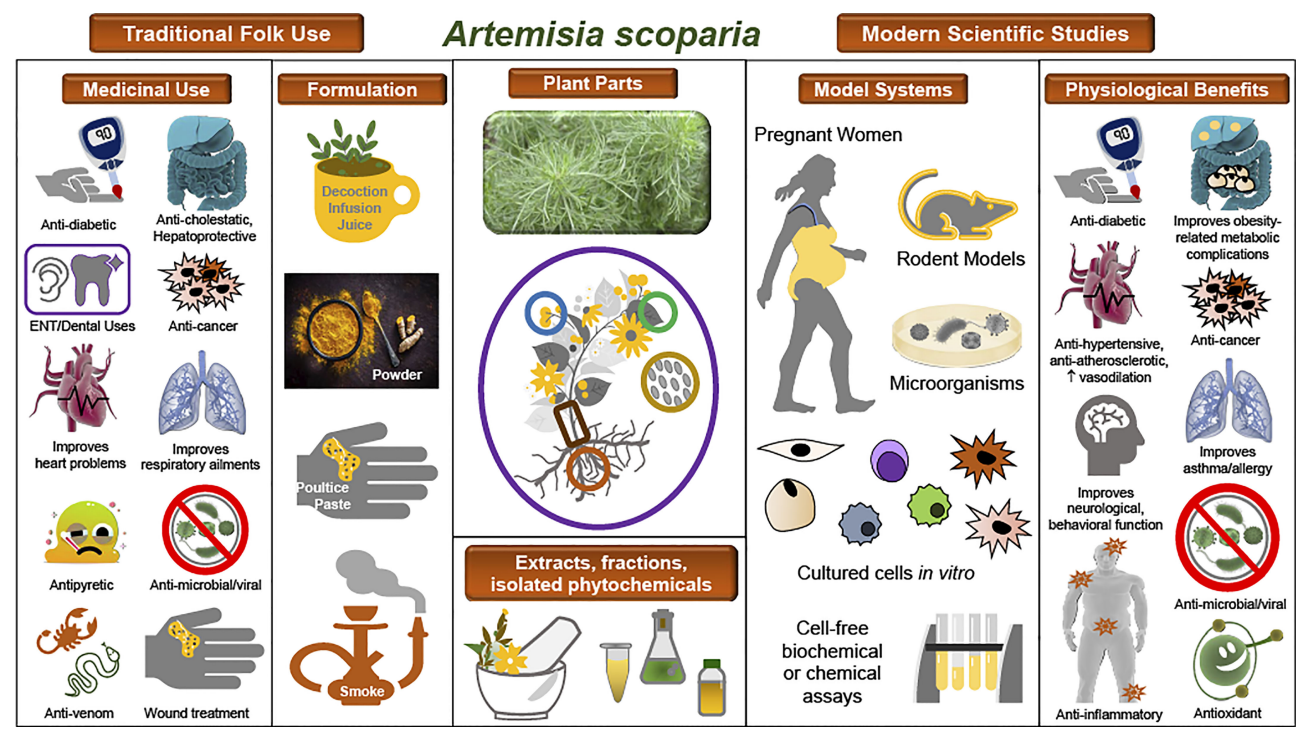

FIGURE 1 | Traditional uses and observed biological effects of $A$. scoparia and its constituents. Illustration of the ethnopharmacology of $A$. scoparia, experimental models used in the study of its bioactivity, and its principal observed effects in pathophysiological conditions. Center: A photograph of $A$. scoparia is shown along with a diagram of the plant parts used in traditional medicine and in modern studies. For use or study of SCOPA, extracts, fractions, or isolated bioactive compounds have been obtained from its flowers, leaves, stems, roots, and seeds, as well as the whole plant. Left: Traditional folk medicine indications and formulations as documented in ethnobotanical studies. Right: Modern scientific studies have included numerous model systems, such as humans, rodents, and microorganisms; in vitro studies in differentiating and mature adipocytes, immune cells, and cancer cells; and cell-free assays of antioxidant or enzymatic activities. Data from scientific studies support some of the ethnopharmacology claims and reveal additional pathophysiologies that may benefit from use of SCOPA extracts or its isolated bioactive constituents.

small Spring seedlings (Mian Yin Chen) and that from flowering plants in late Summer (Yen Chin Hao), each preferable for treating distinct sets of ailments $(41,45)$. Chemical analyses of ASH have confirmed that its constituents vary greatly depending on the time of harvest $(36,46)$. While TCM preparations are derived from the aerial parts of SCOPA, the roots of the plant are used in Pakistan (27) and the use of its flowers has been reported in Iran (16).

\section{EFFECTS OF A. SCOPARIA ON DETERMINANTS OF METABOLIC HEALTH}

\section{Metabolically Favorable Effects of A. scoparia in Experimental Models of Obesity and Diabetes}

As mentioned above, the use of SCOPA in folk medicine for diabetes and hyperglycemia has been amply documented. A 2016 study found that administration of SCOPA during the second trimester of pregnancy improved insulin sensitivity, fasting plasma glucose levels, and circulating adiponectin levels in patients with gestational diabetes (47). With the exception of that study, SCOPA has not been evaluated in humans for effects on measures of metabolic health such as insulin sensitivity, glycemic control, or cardiovascular risk factors. Likewise, few animal studies have been conducted to examine SCOPA's metabolically relevant effects. However, in a mouse model of diet-induced obesity (DIO) and insulin resistance, SCOPA administration by gavage or supplementation of diet was found to improve insulin sensitivity as measured by homeostatic model assessment for insulin resistance (HOMA-IR) or insulin tolerance test (ITT) (48-50). Circulating levels of triglycerides, free fatty acids (FFAs), glycerol, and insulin (fasting) were reduced, while adiponectin levels were increased (49-51). In liver, SCOPA supplementation reduced hepatic triglyceride and cholesterol content and enhanced insulin-induced phosphorylation of the signaling proteins insulin receptor substrate (IRS-1), insulin receptor subunit beta (IR $\beta$ ), protein kinase B (AKT1), and RAC-beta serine/threonine protein kinase (AKT2) (50). Moreover, adenosine monophosphate (AMP)activated protein kinase (AMPK) activity was enhanced and expression levels of genes involved in de novo lipogenesis were reduced by SCOPA in liver, consistent with the observed improvements in hepatic lipid accumulation (50). SCOPA also had pronounced effects in adipose tissue (AT), where it was shown to robustly enhance insulin-induced phosphorylation of AKT protein in epididymal, but not retroperitoneal or inguinal, white adipose tissue (WAT) depots (49). Levels of monocyte chemoattractant protein 1 (MCP-1), an inflammatory cytokine known to be highly expressed in obesity and insulin resistance, were also significantly reduced in SCOPA-treated animals (48).

\section{Pro- and Anti-Adipogenic, and Anti-Lipolytic Effects of $A$. scoparia in Adipocytes}

As described above, an ethanolic extract of SCOPA has metabolically favorable effects in a mouse model of DIO, including improvements in adipose tissue function. This same extract has been shown to enhance adipogenesis of 3T3-L1 cells, a widely used model to study adipocyte differentiation, as measured 
by both lipid accumulation and adipogenic gene expression (48). A recent study has revealed that SCOPA can promote adipogenesis in the absence of 3-isobutyl-1-methylxanthine (MIX), a key component in the classic adipocyte differentiation cocktail, and SCOPA significantly induces the expression of several PPAR $\gamma$ target genes, also regulated by MIX, that enhance lipid accumulation during adipogenesis. These data suggest that SCOPA's adipogenic effects are partially mediated by increased PPAR $\gamma$ activity (52). Another research group investigating individual compounds isolated from a different SCOPA extract reported that 4 of the 19 compounds tested significantly inhibited lipid accumulation in 3T3-L1 cells during differentiation, while other compounds enhanced adipocyte development (53). In this study, no total or parent extracts of SCOPA were tested. A third laboratory observed inhibition of lipid accumulation in 3T3-L1 cells with their crude SCOPA extract as well (54). These apparent discrepancies illustrate three great challenges that accompany the study of botanical extracts: Individual compounds have complex interactions and often fail to mirror effects observed with the parent extracts; plants from different geographic regions, grown in different conditions or harvested at different times of the year may have very different chemical compositions; and variable extraction methods across studies make it impossible to confidently compare results.

Given that obesity drives insulin resistance and diabetes, interventions to reduce fat mass have been pursued as a means to counter obesity-associated metabolic disease. Lowering adiposity through increased energy expenditure or reductions in food intake can indeed have favorable metabolic effects. However, adipogenesis is typically impaired, not enhanced, in obese and insulin resistant states, and limiting adipose tissue expansion in conditions of positive energy balance by inhibiting adipocyte development is generally considered detrimental, as it promotes dyslipidemia and ectopic lipid accumulation (55). This point is underscored by the fact that drugs such as the thiazolidinediones (TZDs), which stimulate adipogenesis via PPAR $\gamma$ activation, are potent insulin sensitizers (56). Since TZDs have fallen out of use in recent years due to significant side effects, efforts are ongoing to identify natural product partial agonists of PPAR $\gamma$ to combat metabolic syndrome (57-60). Researchers investigating SCOPA in adipocytes have employed these alternate strategies (inhibition or promotion of adipogenesis) and have therefore focused on different bioactivities in SCOPA. It should be noted that unlike the pro-adipogenic extract described above, SCOPA extracts that were found to inhibit adipogenesis have not been evaluated in vivo for effects on insulin sensitivity, lipid metabolism, or glycemic control.

Obesity and insulin resistance result in abnormally high rates of lipolysis in the fed state, driven by the impaired action of insulin to inhibit lipolysis, as well as by the chronic inflammation characteristic of obese states (61). As mentioned previously, SCOPA supplementation in the food of high-fat diet-fed mice lowered circulating FFAs and glycerol, consistent with reduced lipolysis rates in adipose tissue (62). In cultured adipocytes, inflammation-associated lipolysis was inhibited in the presence of this same SCOPA extract, indicating that SCOPA has cell- autonomous antilipolytic activity in adipocytes. Interestingly, lipolysis induced by adrenergic stimulation or unstimulated basal lipolysis were not altered by SCOPA (62). A different SCOPA extract has been shown to modestly increase lipolysis in adipocytes under basal conditions but was not tested in inflammatory conditions (63). Given that unstimulated lipolysis rates are very low, this observation may not be relevant in the context of obesity, where inflammatory cytokines drive high lipolysis rates.

\section{Hepatoprotective Effects of $A$. scoparia}

Liver and gallbladder conditions including jaundice and cholestasis are among the illnesses most commonly treated with Yinchen $(A$. scoparia or A. capillaris). Research aimed at characterizing these hepatoprotective and choleretic properties has focused mostly on TCM formulations containing Yinchen in combination with other herbs, or on individual compounds isolated from Yinchen, rather than on the Artemisia extracts. However, two studies by Gilani et al. have demonstrated that SCOPA extract could attenuate liver injury induced by acetaminophen in mice (64) or by carbon tetrachloride in rats (65). Hepatic glucose output and lipid metabolism are major contributors to the regulation of circulating glucose and lipid levels, and thus liver function is key in preserving metabolic homeostasis. Likewise, metabolic dysregulation in obesity can lead to ectopic lipid accumulation in liver and non-alcoholic fatty liver disease (NAFLD). It is therefore plausible that beneficial effects of SCOPA in liver could preserve glycemic control and maintain appropriate circulating lipid levels in conditions of hepatic stress or, conversely, protect the liver from the deleterious effects of obesity and insulin resistance. This is supported by the mouse DIO study described above, in which SCOPA improved insulin sensitivity and reduced hepatic lipid accumulation (50).

\section{Anti-Inflammatory and Antioxidant Effects of $A$. scoparia}

Obesity and T2DM are considered inflammatory states. Infiltration of macrophages and altered resident immune cell populations in adipose tissue promote inflammation and insulin resistance $(66,67)$. Many conditions treated by SCOPA in TCM or folk medicine have an inflammatory component [(41) and Table 1], and SCOPA has been shown to have anti-inflammatory properties in a wide range of conditions, including inhibition of heat-induced protein denaturation in vitro (68) and reducing inflammatory cytokine production, cell infiltration, and edema in carrageenan-induced acute inflammation in rats and mice (69, 70). Similarly, topical application of SCOPA diminished clinical symptoms, cell infiltration, inflammatory cytokine levels, caspase- 1 activity in lesions, and circulating levels of histamine in a mouse model of atopic dermatitis (71). Reductions in markers of adipose tissue inflammation in DIO mice have also been observed with SCOPA supplementation $(48,49)$. In addition, there are abundant data showing anti-inflammatory actions of SCOPA in cultured cell lines relevant to metabolic function. In lipopolysaccharide (LPS)-stimulated RAW 246.7 murine macrophages, an ethanolic SCOPA extract, previously found to attenuate lipolysis and markers of adipose tissue inflammation, also inhibited the expression of several 
inflammatory genes (72). In this same cell line, a different ethanolic extract reduced nitric oxide (NO) production in cells treated with LPS and interferon gamma (IFN $\gamma$ ) (53), while a methanolic extract from a third source failed to inhibit NO release from LPS-treated RAW 264.7 cells (63). Although the reason for this discrepancy cannot be ascertained, the three studies investigated extracts prepared from different plant material originating from diverse geographic locations, using various extraction methods and solvents, and tested at different doses; one or more of these factors could explain these seemingly conflicting results. Similar studies were conducted in isolated bone marrow-derived macrophages (BMDM) from mice, in which NO, inducible nitric oxide synthase (iNOS), and inflammatory cytokine levels were all reduced by SCOPA treatment in stimulated cells (69). Comparable effects of SCOPA have been observed in the THP-1 human monocyte cell line, undifferentiated 3T3-L1 murine preadipocytes, and in the HMC-1 human mast cell line $(69,73)$. Moreover, reduced pro-inflammatory NF- $\kappa \mathrm{B}$ promoter activation in IL- $1 \beta$-treated pancreatic beta-cells, which are also vulnerable to obesity-related inflammation, has been observed in response to SCOPA (72). Taken together, these data from multiple models and treatment conditions clearly indicate that SCOPA is a potent antiinflammatory agent and that it can antagonize inflammation in conditions consistent with metabolic dysregulation.

Oxidative stress plays an important role in insulin resistance, the progression to diabetes, and diabetic complications. Indeed, hyperglycemia induces the production of reactive oxygen and nitrogen species, and the resulting oxidation of lipids, proteins, and DNA mediates diabetic complications such as neuropathy, nephropathy, retinopathy, and vascular damage. Although oxidative stress occurs in response to hyperglycemia, it can also drive metabolic dysfunction, as it hinders insulin signaling and glucose uptake in cultured adipocytes, myocytes, and vascular smooth muscle cells (74-80). Mechanisms involved in these effects have been attributed to mitochondrial dysfunction, inhibition of insulin signaling proteins, and negative modulation of the expression and translocation of the glucose transporter GLUT-4 [reviewed in (80)]. Furthermore, reactive oxygen species (ROS) have a range of deleterious effects on pancreatic beta-cell function, including increased apoptosis, reduced beta- cell neogenesis, mitochondrial dysfunction, and impaired insulin secretion $(78,81)$. Finally, oxidative stress can contribute to insulin resistance by activating inflammatory pathways (80). Essential oils and extracts of SCOPA have been reported to have antioxidant and free radical-scavenging properties (82-85), which could be consistent with improvements in metabolic function. Studies and reviews of SCOPA's anti-inflammatory and antioxidant effects are shown in Table 2.

\section{Cardiovascular Effects of $A$. scoparia}

Metabolic syndrome is a cluster of risk factors for cardiovascular disease and diabetes. Obesity, insulin resistance, and diabetes promote hypertension, hyperlipidemia, and vascular damage, thereby increasing risks of coronary artery disease, stroke, and peripheral vascular disease. SCOPA has been used as an antihypertensive, a vasodilator, and an anti-hypercholesterolemic agent in traditional medicine (Table 1), and data from modern studies have been consistent with these historical uses. As is the case for SCOPA's hepatoprotective properties, investigations have focused on SCOPA-containing TCM preparations or on single compounds isolated from SCOPA, but Cho et al. have shown that diet supplementation with an aqueous SCOPA extract lowered blood pressure and produced other favorable effects in spontaneously hypertensive rats (88). Beneficial effects included reductions in angiotensin converting enzyme (ACE) activity, angiotensin II (AngII) levels, and lipid peroxidation in serum. Given these observations, it is plausible that SCOPA's effects on the cardiovascular system could mitigate some of the complications of metabolic syndrome or diabetes. Studies showing cardiovascular effects of SCOPA appear in Table 2.

\section{EFFECTS OF BIOACTIVE COMPOUNDS FOUND IN A. SCOPARIA}

\section{Coumarins}

SCOPA is rich in plant coumarins (93). The three related coumarins scoparone (6,7 - dimethoxycoumarin), scopoletin (7-hydroxy-5-methoxycoumarin), and esculetin (6,7 dihydroxycoumarin) are found in many Artemisia species and

TABLE 2 | In vitro and in vivo studies of $A$. scoparia.

\begin{tabular}{|c|c|c|c|c|c|c|c|c|}
\hline Extract & $\begin{array}{c}\text { Metabolic } \\
\text { Complications }\end{array}$ & $\begin{array}{l}\text { Cardiovascular/ } \\
\text { dyslipidemia }\end{array}$ & $\begin{array}{l}\text { Hepatic } \\
\text { dysfunction }\end{array}$ & Cancer & $\begin{array}{l}\text { Inflammation/ } \\
\text { oxidative stress }\end{array}$ & $\begin{array}{l}\text { Neurological/ } \\
\text { Behavioral }\end{array}$ & Anti-microbial & Renal \\
\hline Ethanolic extract & $(48-50,62,72,86)$ & (62) & & & (72) & & & \\
\hline Aqueous Extract or fraction & & (88) & & & $(68,69)$ & (89) & & \\
\hline Total flavonoid & & & & & $(68,90)$ & & & \\
\hline Essential oil & & & & & $(82,91)$ & & (92) & \\
\hline Crude extract & (54) & & (65) & & (68) & & & \\
\hline $\begin{array}{l}\text { Whole extract, n.s. }{ }^{\text {b }} \text { or } \\
\text { butanol fraction }\end{array}$ & & & & & (71) & & & \\
\hline
\end{tabular}


are considered major components of SCOPA (36, 41). Many coumarins have potent anti-inflammatory or antioxidant effects that account for a wide range of bioactivities (94). In addition, natural and synthetic coumarins are under investigation as promising treatments for many conditions, cancer in particular (95-102). The therapeutic potential of these coumarins is supported by molecular docking analyses $(94,103-112)$ and structure-activity relationship (SAR) studies (111, 113-117).

\section{Scoparone}

Scoparone, a prominent compound in TCM preparations, has long been known to have hypotensive and vasodilatory properties (118125) and has been found to have several additional favorable cardiovascular effects, including inhibition of ACE activity in vitro (126) and reduction in AngII-induced myocardial changes in rodents, cultured myocytes, and cardiac fibroblasts $(127,128)$. Furthermore, there is evidence that scoparone can mitigate cardiac ischemia/reperfusion injury in in vitro and in vivo settings (129). Scoparone also has anti-atherogenic effects including the inhibition of vascular smooth muscle cell proliferation and migration (130, 131), inhibition of platelet aggregation (132), and the attenuation of atherosclerotic plaque formation and dyslipidemia in hyperlipidemic diabetic rabbits $(133,134)$. One study also found that scoparone decreased peroxisome proliferator-activated receptor gamma (PPAR $\gamma$ ) activity, expression of PPAR $\gamma$ target genes, and lipid accumulation in differentiating 3T3-L1 adipocytes (135). In cultured rat mesangial cells, high glucoseinduced production of extracellular matrix proteins was reduced with scoparone treatment (136), a finding with potential implications for renal diabetic complications.

As is the case for SCOPA extracts and traditional preparations, hepatoprotective effects have been reported for scoparone in NASH $(137,138)$ and in conditions of hepatotoxicity or liver injury induced by carbon tetrachloride or alcohol (139-141). Consistent with folk uses of SCOPA in the treatment of jaundice and cholestasis, scoparone also promotes bilirubin clearance through activation of the constitutive androstane receptor (CAR) (142). Interestingly, CAR activation has been shown to improve insulin sensitivity, glucose metabolism, and hepatic lipid accumulation in leptin-deficient $o b / o b$ mice (143), and to prevent obesity, insulin resistance, and hepatic steatosis in HFD-fed mice (144). CAR agonism has been proposed as a therapeutic target for obesity, insulin resistance, and diabetes (142-146). In a recent study, a panel of natural and synthetic coumarin derivatives was screened for the ability to activate CAR, and scoparone was found to improve glucose tolerance in leptin receptor-null $d b / d b$ mice (147).

Anti-inflammatory and antioxidant properties of scoparone have been demonstrated in a wide range of conditions, and some of the pathways impacted by these effects have been described. Studies in the murine RAW 264.7 macrophage cell line demonstrated that scoparone could attenuate the LPS- or IFN $\gamma$ induced production of inflammatory cytokines, as well as iNOS and cyclooxygenase 2 (COX2) protein levels and corresponding NO and prostaglandin E2 (PGE2) release (148). Similar results were obtained in a human monocyte cell line, in which scoparone attenuated phorbol-12-myristate-13-acetate (PMA)-induced inflammatory cytokine production by inhibiting nuclear factor kappa-light-chain-enhancer of activated B cells $(\mathrm{NF}-\kappa \mathrm{B})$ activation (149).

In a mouse model of acute lung injury, pulmonary edema, histological changes, and LPS-mediated inflammatory cytokine production were improved by scoparone in vivo, while in vitro experiments in alveolar macrophages revealed that the compound's anti-inflammatory effects were mediated through the toll-like receptor 4 (TLR4)/NFKB pathway (150). Anti-inflammatory effects of scoparone in a rat model of colitis have also been reported (151), while in BV2 microglial cells, scoparone attenuated LPS-induced neuroinflammatory responses by blocking interferon regulatory factor 3 (IRF3) and extracellular signal-regulated kinase (ERK) activation (126). In a mouse model of acute seizures, scoparone preserved blood-brain barrier integrity, prevented inflammation and apoptosis, and inactivated the phosphoinositide 3-kinase (PI3K)/AKT signaling pathway in vivo. This same study determined that scoparone could also inhibit astrocyte activation elicited by LPS (152).

In addition to interfering with inflammatory pathways, scoparone has been shown to provide protection from oxidative stress, as demonstrated in 2,2-diphenyl-1-picrylhydrazyl (DPPH) and lipid peroxidation assays in vitro $(151,153)$, and to inhibit production of ROS and preserve antioxidant enzyme activity in response to several types of oxidative stressors $(154,155)$. Antioxidant activity has also been implicated in scoparone's ability to protect against kidney damage elicited by the chemotherapeutic agent cisplatin (156), to reduce markers of pancreatic fibrosis in cultured pancreatic stellate cells (157), and to prevent osteoclast differentiation and bone resorption in vitro (158).

Effects of scoparone have been observed in many other systems and models, including immunosuppressive functions associated with autoimmunity, allergies, and graft rejection (159, 160); neurite outgrowth and dopamine synthesis and release in the PC12 neuronal cell line (161-163); proliferation and migration of cancer cells $(105,164)$; bactericidal, antifungal, and antiparasitic properties (165-167); promotion of melanogenesis; and activation of the cystic fibrosis transmembrane conductance regulator (CFTR) $(168,169)$. Table 3 presents a summary of the wide range of bioactivities attributed to scoparone.

\section{Scopoletin}

Scopoletin is a naturally fluorescent compound found in many plants $(191,214,215,246)$. It is a substrate for peroxidases, which convert scopoletin to non-fluorescent compounds, and has thus been widely used for many decades, in combination with horseradish peroxidase, as the basis for high-sensitivity hydrogen peroxide detection assays (495-498). Several studies have demonstrated scopoletin's antioxidant capabilities in vitro, using common cell-free methods such as the DPPH, Trolox equivalent antioxidant capacity (TEAC), ferric reducing ability of plasma (FRAP), or beta-carotene/bleaching assays, while superoxide, hydrogen peroxide, nitric oxide, and peroxynitrite are among the reactive species shown to be effectively scavenged by scopoletin $(114,180,216-223,247)$. Hepatoprotective antioxidant effects of scopoletin have also been observed in cultured HepG2 cells and primary hepatocytes (154, 200), 
TABLE 3 | In vitro and in vivo effects of bioactive compounds found in A. scoparia.

\begin{tabular}{|c|c|c|c|c|c|c|c|c|c|c|c|}
\hline Compound & $\begin{array}{c}\text { Metabolic } \\
\text { Complications }\end{array}$ & $\begin{array}{l}\text { Cardiovascular/ } \\
\text { dyslipidemia }\end{array}$ & $\begin{array}{c}\text { Hepatic } \\
\text { dysfunction }\end{array}$ & Cancer & $\begin{array}{c}\text { Inflammation/ } \\
\text { oxidative } \\
\text { stress }\end{array}$ & $\begin{array}{c}\text { Neurological/ } \\
\text { Behavioral }\end{array}$ & $\begin{array}{c}\text { Anti- } \\
\text { microbial }\end{array}$ & Renal & Reproduction & $\begin{array}{l}\text { Asthma/ } \\
\text { Allergy }\end{array}$ & Other \\
\hline \multicolumn{12}{|l|}{ Coumarins } \\
\hline Scoparone & $\begin{array}{c}(132-136 \\
147)\end{array}$ & $(119,122-134)$ & $\begin{array}{c}(137,138 \\
140,142, \\
154,170- \\
174)\end{array}$ & $\begin{array}{l}(105 \\
164)\end{array}$ & $\begin{array}{c}(149-151 \\
153-155,157 \\
175,176)\end{array}$ & $\begin{array}{l}(126,152, \\
161-163)\end{array}$ & $\begin{array}{l}(165- \\
167)\end{array}$ & $\begin{array}{l}(136 \\
156)\end{array}$ & $(177)$ & $\begin{array}{l}(159 \\
160 \\
175)\end{array}$ & $\begin{array}{l}(178)^{a} \\
(158, \\
179))^{b} \\
(169) ;^{c}\end{array}$ \\
\hline Scopoletin & $\begin{array}{l}(108,116, \\
180-190)\end{array}$ & $\begin{array}{c}(126,132,191- \\
199)\end{array}$ & $\begin{array}{c}(154,200- \\
202)\end{array}$ & $\begin{array}{l}(97 \\
203- \\
213)\end{array}$ & $\begin{array}{l}(114,154 \\
214-245)\end{array}$ & $\begin{array}{l}(106,109, \\
110,227, \\
246-264)\end{array}$ & $\begin{array}{c}(165, \\
265-278)\end{array}$ & & $(279)$ & $\begin{array}{l}(175 \\
251 \\
280- \\
288)\end{array}$ & $\begin{array}{c}(289, \\
290)^{d} \\
(291- \\
293)^{b}{ }^{b} \\
(294, \\
295)^{\circ}{ }^{\circ} \\
(296- \\
298)^{\cdot a}\end{array}$ \\
\hline Esculetin & $\begin{array}{l}(116,180 \\
299-312)\end{array}$ & $(303,313-317)$ & $\begin{array}{l}(139,171 \\
318-320)\end{array}$ & $\begin{array}{l}(96 \\
321- \\
349)\end{array}$ & $\begin{array}{c}(226,307 \\
318,350-366)\end{array}$ & $\begin{array}{c}(111,367- \\
372)\end{array}$ & $\begin{array}{c}(165, \\
314,373- \\
375)\end{array}$ & $\begin{array}{l}(107, \\
339, \\
376- \\
378)\end{array}$ & (379) & $\begin{array}{l}(282, \\
354, \\
380- \\
383)\end{array}$ & $\begin{array}{l}(384- \\
386)^{b} \\
(387, \\
388)^{f} \\
(389)^{q}\end{array}$ \\
\hline \multicolumn{12}{|l|}{ Flavonoids } \\
\hline Flavonols $^{\mathrm{h}}$ & $(57,390-397)$ & $(395,398-402)$ & $\begin{array}{c}(395,403, \\
404)\end{array}$ & $\begin{array}{l}(395, \\
405 \\
406)\end{array}$ & $(395,407)$ & $(393,395)$ & $\begin{array}{l}(395 \\
408)\end{array}$ & $(395)$ & & (395) & $\begin{array}{l}(395, \\
409)\end{array}$ \\
\hline Rutin & $\begin{array}{l}(394,397, \\
410-416)\end{array}$ & $(402,417)$ & $\begin{array}{l}(412,415 \\
418-421)\end{array}$ & $\begin{array}{l}(422, \\
423)\end{array}$ & $\begin{array}{l}(419,420 \\
424,425)\end{array}$ & & & $\begin{array}{l}(418 \\
420)\end{array}$ & $(418,420)$ & $(417)$ & $\begin{array}{l}(421)^{d} \\
(412, \\
425)^{e}{ }^{e}\end{array}$ \\
\hline Flavanones $^{i}$ & (426-429) & $(427,430,431)$ & $(432)$ & $\begin{array}{l}(427 \\
433)\end{array}$ & $\begin{array}{c}(427,428 \\
434)\end{array}$ & & $\begin{array}{l}(435 \\
436)\end{array}$ & & & & $\begin{array}{l}(429)^{\mathrm{b}} \\
(437))^{\mathrm{C}}\end{array}$ \\
\hline \multicolumn{12}{|l|}{ Chromones } \\
\hline Capillarisins & $(116)$ & & $(438,439)$ & $\begin{array}{l}(440- \\
443)\end{array}$ & $(444-449)$ & (448) & & & $(450)$ & $(451)$ & $(452)^{\mathrm{g}}$ \\
\hline \multicolumn{12}{|l|}{ Phenolic } \\
\hline $\begin{array}{l}\text { Chlorogenic } \\
\text { Acids }^{j}\end{array}$ & $(453-455)$ & $(455-458)$ & (459) & $\begin{array}{l}(460 \\
461)\end{array}$ & $\begin{array}{c}(71,73,222, \\
462-464)\end{array}$ & $(465-467)$ & $\begin{array}{l}(468- \\
470)\end{array}$ & & & & $(471)^{d}$ \\
\hline $\begin{array}{l}\text { Prenylated } \\
\text { coumaric } \\
\text { acids }^{k}\end{array}$ & $(472-477)$ & & & $\begin{array}{l}(478- \\
485)\end{array}$ & $\begin{array}{l}(464,472 \\
486-489)\end{array}$ & & $\begin{array}{l}(490 \\
491)\end{array}$ & & & (492) & $\begin{array}{l}(493)^{d} \\
(488) ; \\
(494) ;\end{array}$ \\
\hline
\end{tabular}

a Melanogenesis.

${ }^{b}$ Osteoprotection.

${ }^{c}$ Respiratory.

${ }^{d}$ Aging and healthspan.

eGastrointestinal.

${ }^{f}$ Ophthalmic.

${ }^{g}$ Cartilage or muscle.

${ }^{h}$ Quercetin and Isorhamnetin.

'Naringenin and Blumeatin.

${ }^{j}$ Caffeic acid, Dicaffeoylquinic acids, Chlorogenic acid.

${ }^{k}$ Artepillins, Capillartemisins, Drupanin, Scopa-coumaricins.

'Hypoxia/ischemia.

however one study failed to detect significant antioxidant activity for scopoletin (499).

Given the important role of oxidative stress in the etiology of numerous disorders, it is not surprising that some of scopoletin's favorable effects in disease states are attributed to its antioxidant properties. For example, scopoletin has been reported to have antioxidant effects in hyperthyroid-induced hyperglycemia in rats (224), as well as in oxidant-induced hemolysis of rat erythrocytes (225). The brain is particularly vulnerable to oxidative stress, which is known to be central to many neurodegenerative conditions (500).
A study performed in mouse brain homogenates revealed that scopoletin strongly inhibited the oxidative protein modifications induced by copper (226), which can contribute to the pathologies associated with atherosclerosis, Alzheimer's disease (AD), and Wilson's disease (501-503). A recent study examined several aspects of oxidative stress involved in the pathogenesis of Parkinson's disease (PD) and showed that scopoletin attenuated depletion of cellular reduced glutathione or ATP, inhibited ROS generation, and prevented cell death in oxidative conditions in vitro (227). These findings were extended to a Drosophila mutant model 
of PD, where scopoletin treatment reduced accumulation of mitochondrial ROS and promoted recovery from degenerative phenotypes (227). Several other studies have shown that scopoletin can prevent oxidative injury in models relevant to diseases such as PD and AD. These include prevention of oxidative injury and induction of antioxidant gene expression in HT-22 and SHSY-5Y cells $(248,249)$, as well as inhibition of monoamine oxidase activity $(106,250)$.

One important contributor to oxidative stress in many cell types is the xanthine oxidase $(\mathrm{XO}) /$ xanthine dehydrogenase $(\mathrm{XDH})$ system $(201,504,505)$. XO activity in the liver produces uric acid, which is released into circulation and excreted by the kidney. Hyperuricemia, due to excessive uric acid production in the liver or impaired clearance in the kidney, causes accumulation of uric acid crystals in joints (gout) and in the kidney. Scopoletin shows inhibitory activity in enzymatic assays of XO in vitro (506). Additionally, scopoletin administered either by intraperitoneal injection or by oral gavage of scopoletin-loaded micelles was shown to correct hyperuricemia in mice through two separate mechanisms, namely inhibiting hepatic XO activity and enhancing uric acid excretion by the kidney (201, 202). Notably, $\mathrm{XO}$ activity is associated with obesity-related metabolic dysfunction, and XO inhibitors typically prescribed for gout or hyperuricemia are proving to be effective in mitigating cardiovascular and renal complications of diabetes $(504,507,508)$.

In addition to antioxidant effects, scopoletin has potent antiinflammatory activity. Numerous studies have demonstrated the ability of scopoletin to diminish the production of proinflammatory mediators such as cytokines and eicosanoids in many cell types, including macrophages, mast cells, fibroblasts, and platelets (228237). In vivo effects of scopoletin in rodent ear or paw edema models and in models of inflammatory conditions such as arthritis, gastroesophageal disease, gastric ulcers, gout, pleurisy, pancreatitis, as well as nociceptive or analgesic properties, have also been described $(215,237-242,291,509,510)$. Mechanisms involved in scopoletin's anti-inflammatory effects include negative regulation of inflammatory signaling pathways and inhibition of lipoxygenase and cyclooxygenase enzyme activities $(214,239,243,247,280,281)$. Scopoletin's anti-inflammatory properties have also been implicated in its effects on various pathologies, particularly in the realm of immunity, as it has been shown to regulate complement pathway activation, mast cell degranulation, as well as several aspects of innate, humoral, and adaptive immune function, suggesting potential roles in allergies, asthma, and autoimmune diseases such as multiple sclerosis and rheumatoid arthritis (175, 251, 282-288, 511).

Scopoletin has been studied in several models of neurological dysfunction and has an array of favorable effects. Some of these are at least partly attributable to its antioxidant or anti-inflammatory properties, like reducing inflammation-induced anxiety in mice or attenuating neural deficits, brain edema, and inflammatory cytokine production in intracerebral hemorrhage in rats (252, 253). In addition, several groups have demonstrated scopoletin's ability to inhibit acetyl- and butyryl-cholinesterases in vitro (110, 247, 254-257, 512) and in vivo (258). Antidepressant, antipsychotic, and anti-amnesic effects were also observed in behavioral studies in mice $(246,258-261)$. A study investigating anticonvulsant effects of Benkara malabarica (Linn.) root extract found that scopoletin inhibited GABA transaminase activity (262). Consistent with this finding, molecular docking analysis has demonstrated affinity of scopoletin for both GABA transaminase and for the GABA-A receptor (252). The anticonvulsant drug vigabatrin is an irreversible inhibitor of GABA-T, and there is convincing evidence that it is effective in attenuating anxiety symptoms (513). Formation of amyloid beta peptide 42 (A $\beta 42$ ) and $\alpha$-synuclein fibrils, processes central to the pathogenesis of $\mathrm{AD}$ and $\mathrm{PD}$ respectively, have both been shown to be inhibited by scopoletin $(109,110)$. These actions are likely complementary to the antioxidant mechanisms described above (227) in combatting neurodegenerative diseases. Finally, scopoletin improves neuronal plasticity, as measured in ex vivo electrophysiological assays, and exerts neuroprotective activity in a rat spinal cord injury model $(263,264)$.

In conditions related to metabolic health, scopoletin acts favorably on many pathways in vivo, as well as in various cell types and experimental conditions. In animal models of diet-induced obesity, diabetes, or alcohol-induced metabolic dysfunctions, scopoletin restored insulin sensitivity, reversed disruptions in circulating lipids, glucose, insulin, and inflammatory cytokines, while also attenuating lipid accumulation and fibrosis in liver, restoring adiponectin levels in white adipose tissue, and reducing oxidative stress in the pancreas (181-187). Consistent with these in vivo observations, scopoletin has been shown to mitigate insulin resistance and improve metabolic functions in cultured hepatocytes, adipocytes, and pancreatic beta-cells (184, 185, 188, 514). In vitro assays have revealed that enzymes involved in glucose homeostasis (protein tyrosine phosphatase $1 b, \alpha$-glucosidase and $\alpha$ amylase) or in diabetic complications (aldone reductase) are inhibited by scopoletin $(108,116,180,184,187,189,190)$. While effects described above are likely to improve cardiovascular health in the context of metabolic syndrome, scopoletin also acts directly on the heart and vasculature. Scopoletin has antihypertensive actions (126, 191-193), anti-atherosclerotic capabilities (132, 194-196), and vascular spasmolytic/vasodilatory effects (191, 193, 197-199).

Scopoletin is a compound of interest in cancer research, as it has been shown to have apoptotic, cytotoxic, anti-proliferative, anti-angiogenic, and anti-metastatic activities in various cancer cell lines (97, 203-212). Efforts are ongoing to develop synthetic derivatives of scopoletin and to characterize and improve its bioavailability and pharmacokinetic properties (96). Finally, a handful of other bioactivities have been reported for scopoletin, among them the promotion of melanogenesis (296-298) and osteoprotective $(292,293)$, antitussive (515), gastrokinetic (294), and antimicrobial properties $(165,265-278,516)$, as well as antiaging effects in skin and lung fibroblasts $(289,290)$.

It is notable that many of the same signaling pathways are modulated by scopoletin across the wide variety of experimental models and conditions in which it has been investigated. Scopoletin can activate the AMPK pathway (181, 182, 186, $263,514)$ and the PI3K/AKT pathway $(184,186,188,514)$, and inhibit the inflammatory TLR4/myeloid differentiation factor 88 (MyD88) and NF- $\kappa$ B pathways (94, 181, 183, 233, 
$237,241,251,252,517,518)$. There is also substantial evidence that scopoletin can inhibit the MAPK pathway in a variety of cell types (199, 235, 237, 241, 252, 290, 297).

\section{Esculetin}

Like scoparone and scopoletin, esculetin's well-documented antioxidant and anti-inflammatory properties are central to its beneficial effects in biological systems (226, 350-355, 384, 519). A broad range of inflammatory or oxidative conditions have been shown to be impacted by esculetin. These include lung injury and fibrosis (356, 357, 520); fibromyalgia (521); neuronal oxidative stress (522); psoriasis (523); arthritis (358); nociception (359); colitis (360); allergy, immunity, and asthma (282, 354, 380-383); and sepsis (361). The effects of esculetin on numerous cancer cell types have been extensively studied (94, 321-342, 519, $524,525)$ and are the basis for efforts to develop novel therapeutics $(98,341)$. Neuroprotective and behavioral actions of esculetin have also been described $(111,299,367-371,526-$ 528). Selected publications highlighting these effects of esculetin are featured in Table 3.

\section{Flavonoids and Chromones}

Flavonoids are highly abundant compounds in all plants; they are extensively studied for various bioactivities and have a wide range of effects in many biological systems. Numerous flavonoids have been identified in SCOPA, however their relative abundance varies widely among plants and extracts from different sources $(36,41)$. Since there exists abundant literature regarding the bioactivities of flavonoids, we will present only a subset of the most commonly reported, most abundant, or most thoroughly investigated flavonoids in SCOPA. As a representative example, cirsmaritin has been shown to have anti-proliferative, anti-metastatic, and anticarcinogenic effects in cancer cell lines (529-534), diabetes- and metabolism-related effects (535-537), as well as anti-inflammatory, antioxidant, and antimicrobial properties (538-543). Studies have also demonstrated that cirsimaritin can modulate neurological, immune, and digestive functions (544-548), and attenuate renal injury $(549,550)$. Additional activities of selected flavonoids are shown in Table 3.

The chromone capillarisin is known as a major constituent of Artemisia capillaris. It is also relatively abundant in SCOPA but is not known to be a bioactive constituent of other plants. There are multiple reports of anti-inflammatory and antioxidant effects of capillarisin $(444-448,551)$, which has also been shown to inhibit tumor cell invasion, inhibit signaling transducer and activator of transcription 3 (STAT3) activation, slow cell growth, and promote apoptosis in various cancer cell lines (440, 441, 443, 552). Other reported effects of capillarisin include anti-asthmatic activity (451) and promotion of penile erection in a rabbit model (450). Studies of capillarisin and its derivatives that are found in SCOPA are summarized in Table 3.

\section{Phenolic Acids}

Chlorogenic acid, caffeic acid, 3,5-dicaffeoylquinic acid, and 4,5dicaffeoylquinic acid are related phenolic acids found in many plants or, in the case of caffeic acid, all plants. Chlorogenic acid and its derivatives are abundant in SCOPA and have been shown to mediate some of SCOPA's effects $(71,73,85)$. Unlike the ubiquitous chlorogenic acid derivatives, prenylated coumaric acids (PCAs) are not common in plants, and the most thoroughly characterized of these compounds, artepillin C, drupanin, and baccharin, have been primarily studied from Brazilian green propolis (476, 553-555). The most prominent bioactivities of chlorogenic acids and PCAs are presented in Table 3. Although not all studies of SCOPA's chemical constituents have detected PCAs, capillartemisin B and drupanin have been identified in SCOPA $(53,556-558)$, and additional PCAs have been reported in Artemisia capillaris $(559,560)$. PCAs are not considered major constituents of SCOPA, however several of them have been isolated from a SCOPA extract with potent adipogenic activity $(556,557)$. Fractions of this extract that were most effective in promoting adipogenesis were rich in PCAs, and activity was confirmed for three PCAs isolated from these fractions, including two co-purified isomers of a novel PCA, termed "cis-scopa-transcoumaricin" and "cis-scopa-cis-coumaricin". Like the PCAs from SCOPA, PCAs from propolis can activate PPAR $\gamma$, promote adipocyte differentiation, and mitigate obesity-associated metabolic dysfunction (472-474, 561-563). Given that these compounds have not been reported in SCOPA extracts found to inhibit adipogenesis, the presence or absence of PCAs is a plausible explanation for the seemingly divergent effects of SCOPA on adipocytes in studies using different extract preparations. Interestingly, a unique enzyme has recently been isolated from $A$. capillaris that catalyzes two successive prenylations of $\mathrm{p}$-coumaric acid to yield artepillin $\mathrm{C}$, with drupanin as a mono-prenylated intermediate (564). It appears likely that an equivalent enzyme may exist in SCOPA and in other plants that synthesize these compounds.

\section{BRIDGING THE GAP: SCOPA AS A MODERN INTERVENTION TO PROMOTE METABOLIC HEALTH}

We have reviewed multiple lines of evidence for metabolic benefits of SCOPA. However, these data have emerged in a piecemeal fashion, and comprehensive studies to adequately assess SCOPA as a therapeutic or preventive intervention for metabolic dysfunction are lacking. One ethanolic SCOPA extract has been shown to have beneficial effects on adipose tissue function, hepatic lipid accumulation, and insulin sensitivity in a mouse model of DIO (48-50), and a different extract was found to attenuate gestational diabetes in a small human study (47). Ethnopharmacological data, as well as the broad range of bioactivities of SCOPA observed in various cell lines and disease models, also provide strong rationale to investigate SCOPA in humans with obesity or metabolic syndrome. The widespread medicinal use of SCOPA in many parts of the world suggests favorable safety and toxicity profiles, however these have not been formally studied, and such data will be needed in the assessment of SCOPA's potential as a therapeutic intervention. For example, since SCOPA is known to affect hepatic function and to increase whole-body insulin sensitivity in mice, adverse effects in the liver or risk of hypoglycemia are potential concerns. Given the high variability in the chemical composition of SCOPA extracts, their rigorous characterization, using unbiased and standardized methods will also be crucial in interpreting results from different 
extracts and in guiding pharmacokinetic evaluation of potential therapeutic extracts. In our view, details of extract composition reported for SCOPA are generally insufficient, and greater efforts are required to characterize extracts that are being studied for the promotion of metabolic health. Repositories of serum and tissue samples from in vivo studies would also be helpful in laying the groundwork for pre-clinical or translational studies. Differences in biological effects and chemical composition among various SCOPA preparations could also serve as a resource for correlating constituent compounds with bioactivity.

SCOPA's reported hepatoprotective and antioxidant properties, as well as its beneficial effects on cardiovascular parameters are consistent with favorable metabolic effects but have not been investigated in the context of human metabolic disease. In addition, SCOPA's potential effects in many cell types and experimental models relevant to obesity or metabolic syndrome have not yet been interrogated. These include measures of insulin sensitivity or glucose uptake in skeletal muscle cells, glucose output from hepatocytes, and insulin secretion from pancreatic beta-cells. SCOPA's ability to mitigate diabetic complications is also unknown, although its documented antioxidant and anti-inflammatory effects suggest that it may protect against the consequences of chronic hyperglycemia. All these aspects of SCOPA bioactivity merit more systematic assessment in conditions of metabolic dysfunction. Finally, mechanisms responsible for SCOPA's pleiotropic actions remain only partially explored. As described in this review, SCOPA or its constituent compounds have been shown to regulate various signaling pathways or enzyme activities, but the molecular players, mechanistic details, and implications of these effects remain to be elucidated. Thus, a wide range of experimental observations offer promising evidence of SCOPA's metabolic benefits, but critical pieces of data are needed to realize its full promise as a bona fide therapeutic.

\section{CONCLUSION}

The historical and anthropological importance of botanicals in health and disease is unquestionable. Not only are plants used in folk medicine applications around the world, but they are also consumed as nutritional supplements and are the origin of many modern pharmaceuticals. Despite the successes of synthetic drug development, there is great value in investigating complex botanical extracts for several reasons. First, there is a need to characterize and evaluate botanicals in current use. A cross-sectional study conducted between 2002 and 2012 reported that $18 \%$ of adults in the US use dietary supplements (565). According to the American Botanical Council, sales of botanical supplements topped $8.8 \mathrm{~B} \$$ in 2018 and were on the rise (abc.herbalgram.org). This market is largely unregulated, and rigorous studies addressing the safety, modes of action, and efficacy of such supplements are desirable. Second, synergistic interactions between phytochemical compounds are common, and individual constituents often fail to recapitulate activities of their parent botanical extracts $(566,567)$. Third, the thorough study of complex botanical extracts enables the identification of novel and unique lead compounds that may not otherwise emerge or that may be challenging to synthesize, as in the case of the PCAs reported in Artemisia species including SCOPA.

This review of SCOPA's ethnopharmacology, bioactivities, and constituent compounds reveals a remarkable range of traditional uses and experimental data and provides a valuable example of both the potential and the difficulties of studying complex botanical extracts. Indeed, we have described promising in vivo and in vitro data supporting SCOPA's use for many pathologies, in particular hepatic diseases and obesity-related metabolic dysfunction, as well as proven effects of individual compounds found in SCOPA. Figure 1 illustrates the principal findings related to SCOPA. We have also presented seemingly contradictory data regarding the adipogenic effects of SCOPA, with studies showing both pro- $(48,49,556,557)$ and anti- $(53,54,63)$ adipogenic activities. However, analysis of the pro-adipogenic extract and fractions revealed the presence of PCAs, known to promote adipogenesis, while these compounds were not reported in extracts that inhibited adipogenesis.

To be sure, investigation of botanical extracts is a challenging endeavor due to the enormous complexity of the mixtures, the considerable variability in extract composition from different plants of the same species $(36,46,568,569)$, the potential for unpredictable experimental artifacts (570), the imperfect methods for detecting constituent compounds, and the biased nature of investigations based on the research interests and priorities of different investigators. However, increasingly sophisticated preparatory, analytical, and computational methods are helping to overcome these difficulties. In order to enhance the reliability and translatability of natural products research, the National Center for Complementary and Integrative Health (NCCIH) has spearheaded the development of comprehensive good practices for pre-clinical investigation of natural products (567). We fully support these principles and encourage further study of the bioactivities of Artemisia scoparia, particularly in metabolism research, in accordance with these guidelines.

\section{AUTHOR CONTRIBUTIONS}

A.B. wrote the first draft of the manuscript and prepared the information for the tables. I.H wrote a small part of the review and edited the entire document. AR edited the document and prepared the final version of the Tables and Figure. JS worked with $A B$ on original outline of the review and edited each draft. All authors contributed to the article and approved the submitted version.

\section{FUNDING}

This publication was supported by the National Center for Complementary \& Integrative Health and the Office of Dietary Supplements of the National Institutes of Health (NIH) under Award Number P50AT002776 which funds the Botanical Dietary Supplements Research Center of Pennington Biomedical Research Center and the Department of Plant Biology and Pathology in the School of Environmental and Biological Sciences (SEBS) of Rutgers University. 


\section{REFERENCES}

1. Bora KS, Sharma A. The Genus Artemisia: A Comprehensive Review. Pharm Biol (2011) 49:101-9. doi: 10.3109/13880209.2010.497815

2. Bisht D, Kumar D, Kumar D, Dua K, Chellappan DK. Phytochemistry and Pharmacological Activity of the Genus Artemisia. Arch Pharm Res (2021) 1:3. doi: 10.1007/s12272-021-01328-4

3. Tu Y. Artemisinin-A Gift From Traditional Chinese Medicine to the World (Nobel Lecture). Angew Chemie - Int Ed (2016) 55:10210-26. doi: 10.1002/anie.201601967

4. Tan RX, Zheng WF, Tang HQ. Biologically Active Substances From the Genus Artemisia. Planta Med (1998) 64:295-302. doi: 10.1055/s-2006957438

5. Abad MJ, Bedoya LM, Apaza L, Bermejo P. The Artemisia L. Genus: A Review of Bioactive Essential Oils. Molecules (2012) 17:2542-66. doi: 10.3390/molecules 17032542

6. Abad Martínez MJ, Del Olmo LMB, Ticona LA, Benito PB. The Artemisia L. Genus: A Review of Bioactive Sesquiterpene Lactones. In: Studies in Natural Products Chemistry. Amsterdam, Netherlands: Elsevier B.V. (2012) 37 p. 4365. doi: 10.1016/B978-0-444-59514-0.00002-X

7. Youssef RSA. Medicinal and Non-Medicinal Uses of Some Plants Found in the Middle Region of Saudi Arabia. J Med Plants Res (2013) 7:2501-13. doi: 10.5897/JMPR12.798

8. Parveen, Upadhyay B, Roy S, Kumar A. Traditional Uses of Medicinal Plants Among the Rural Communities of Churu District in the Thar Desert, India. J Ethnopharmacol (2007) 113:387-99. doi: 10.1016/j.jep.2007.06.010

9. Sher H, Bussmann RW, Hart R, De Boer HJ. Traditional Use of Medicinal Plants Among Kalasha, Ismaeli and Sunni Groups in Chitral District, Khyber Pakhtunkhwa Province, Pakistan. J Ethnopharmacol (2016) 188:57-69. doi: 10.1016/j.jep.2016.04.059

10. Hussain W, Badshah L, Ullah M, Ali M, Ali A, Hussain F. Quantitative Study of Medicinal Plants Used by the Communities Residing in Koh-E-Safaid Range, Northern Pakistani-Afghan Borders. J Ethnobiol Ethnomed (2018) 14:30. doi: 10.1186/s13002-018-0229-4

11. Bhat JA, Kumar M, Bussmann RW. Ecological Status and Traditional Knowledge of Medicinal Plants in Kedarnath Wildlife Sanctuary of Garhwal Himalaya, India. J Ethnobiol Ethnomed (2013) 9:1-18. doi: 10.1186/1746-4269-9-1

12. Barkatullah, Ibrar M, Rauf A, Ben Hadda T, Mubarak MS, Patel S. Quantitative Ethnobotanical Survey of Medicinal Flora Thriving in Malakand Pass Hills, Khyber Pakhtunkhwa, Pakistan. J Ethnopharmacol (2015) 169:335-46. doi: 10.1016/j.jep.2015.04.052

13. Mahmood A, Mahmood A, Naseem Malik R, Khan Shinwari Z. Indigenous Knowledge of Medicinal Plants From Gujranwala District, Pakistan. J Ethnopharmacol (2013) 148:714-23. doi: 10.1016/j.jep.2013.05.035

14. Khan M, Kumar S, Hamal IA. Medicinal Plants of Sewa River Catchment Area in the Northwest Himalaya and Its Implication for Conservation. Ethnobot Leafl (2009) 13:1113-52.

15. Au DT, Wu J, Jiang Z, Chen H, Lu G, Zhao Z. Ethnobotanical Study of Medicinal Plants Used by Hakka in Guangdong, China. J Ethnopharmacol (2008) 117:41-50. doi: 10.1016/j.jep.2008.01.016

16. Ghasemi Pirbalouti A, Momeni M, Bahmani M. Ethnobotanical Study of Medicinal Plants Used by Kurd Tribe in Dehloran and Abdanan Districts, Ilam Province, Iran. Afr J Tradit Complement Altern Med (2013) 10:368-85. doi: 10.4314/ajtcam.v10i2.24

17. Hamayun M, Afzal S, Khan MA. Ethnopharmacology, Indigenous Collection and Preservation Techniques of Some Frequently Used Medicinal Plants of Utror and Gabral, District Swat, Pakistan. Afr J Trad CAM (2006) 3:57-63. doi: 10.4314/ajtcam.v3i2.31158

18. Jabeen N, Ajaib M, Siddiqui MF, Ulfat M, Khan B. A Survey of Ethnobotanically Important Plants of District Ghizer, Gilgit-Baltistan. FUUAST J Biol (2015) 5:153-60.

19. Ahmad I, Ibrar M, Barkatullah, Ali N. Ethnobotanical Study of Tehsil Kabal, Swat District, KPK, Pakistan. J Bot (2011) 2011:1-9. doi: 10.1155/2011/368572

20. Singh KN, Lal B, Todaria NP. Ethnobotany of Higher Plants in Spiti Cold Desert of Western Himalaya. Nat Sci (2012) 10(5):7-14

21. Ahmad KS, Hamid A, Nawaz F, Hameed M, Ahmad F, Deng J, et al. Ethnopharmacological Studies of Indigenous Plants in Kel Village, Neelum
Valley, Azad Kashmir, Pakistan. J Ethnobiol Ethnomed (2017) 13:68. doi: 10.1186/s13002-017-0196-1

22. Al-Asmari AK, Al-Elaiwi AM, Athar MT, Tariq M, Al Eid A. Al-Asmary SM. A Review of Hepatoprotective Plants Used in Saudi Traditional Medicine. Evidence-Based Complement Altern Med (2014) 2014:890842. doi: $10.1155 / 2014 / 890842$

23. Chaudhary MI, He Q, Cheng YY, Xiao PG. Ethnobotany of Medicinal Plants From Tian Mu Shan Biosphere Reserve, Zhejiang-Province, China. Asian J Plant Sci (2006) 5:646-53. doi: 10.3923/ajps.2006.646.653

24. Wright M, Watson MF. Tibetan Medicinal Plants. In: C Kletter and M Kriechbaum, editors, vol. 383. Stuttgar: Medpharm Scientific Publishers (2001) p. 77. Edinburgh J Bot (2002). doi: 10.1017/s0960428602260291

25. Safa O, Soltanipoor MA, Rastegar S, Kazemi M, Nourbakhsh Dehkordi K, Ghannadi A. An Ethnobotanical Survey on Hormozgan Province, Iran. Avicenna J Phytomed (2013) 3:64-81. doi: 10.22038/ajp.2012.12

26. Hayat M, Hayat MQ, Khan MA, Ashraf M, Jabeen S. Ethnobotany of the Genus Artemisia L. (Asteraceae) in Pakistan. Ethnobot Res Appl (2009) 7:147-62. doi: 10.17348/era.7.0.147-162

27. Ishtiaq M, Maqbool M, Ajaib M, Ahmed M, Hussain I, Khanam H, et al. Ethnomedicinal and Folklore Inventory of Wild Plants Used by Rural Communities of Valley Samahni, District Bhimber Azad Jammu and Kashmir, Pakistan. PloS One (2021) 16(1):e0243151. doi: 10.1371/ journal.pone.0243151

28. Hussain W, Ullah M, Dastagir G, Badshah L. Quantitative Ethnobotanical Appraisal of Medicinal Plants Used by Inhabitants of Lower Kurram, Kurram Agency, Pakistan. Avicenna J Phytomed (2018) 8:313-29.

29. Naveed M, Hejazi V, Abbas M, Kamboh AA, Khan GJ, Shumzaid M, et al. Chlorogenic Acid (CGA): A Pharmacological Review and Call for Further Research. BioMed Pharmacother (2018) 97:67-74. doi: 10.1016/j.biopha. 2017.10.064

30. Khan SW, Bot PJ, Wali Khan And S, Khatoon S. Ethnobotanical Studies on Some Useful Herbs of Haramosh and Burgote Valleys in Gilgit, Northern Areas of Pakistan. Pakistan J Bot (2008) 40:43-58.

31. Joshi R, Satyal P, Setzer W. Himalayan Aromatic Medicinal Plants: A Review of Their Ethnopharmacology, Volatile Phytochemistry, and Biological Activities. Medicines (2016) 3:6. doi: 10.3390/medicines3010006

32. Abbas Z, Khan SM, Alam J, Khan SW, Abbasi AM. Medicinal Plants Used by Inhabitants of the Shigar Valley, Baltistan Region of Karakorum RangePakistan. J Ethnobiol Ethnomed (2017) 13:53. doi: 10.1186/s13002-017-0172-9

33. Ganie AH, Tali BA, Shapoo GA, Nawchoo IA, Khuroo AA. Ethno-Survey of Traditional Use of Plants as Aphrodisiacs in Kashmir Himalaya, India. J Herb Med (2019) 17-18:100256. doi: 10.1016/j.hermed.2019.100256

34. Rana CS, Sharma A, Kumar N, Dangwal LR, Tiwari JK. Ethnopharmacology of Some Important Medicinal Plants of Nanda Devi National Park (NDNP) Uttarakhand, India. Nat Sci (2010) 8:9-14.

35. China Medical Science Press. Pharmacopoeia of the People's Republic of China: 2015. 10th Ed. Beijing, China: China Medical Science Press (2017).

36. Cai Y, Zheng Q, Sun R, Wu J, Li X, Liu R. Recent Progress in the Study of Artemisiae Scopariae Herba (Yin Chen), a Promising Medicinal Herb for Liver Diseases. BioMed Pharmacother (2020) 130:110513. doi: 10.1016/ j.biopha.2020.110513

37. Youssef A. Medicinal and Non-Medicinal Uses of Some Plants Found in the Middle Region of Saudi Arabia. J Med Plant Res (2013) 7:2501-17. doi: 10.5897/JMPR12.798

38. Yeung H. Handbook of Chinese Herbal Formulas. 2nd Ed. Rosemead, CA: Institute of Chinese Medicine (1995).

39. Nadeem M, Khan Shinwari Z, Qaiser M. Screening of Folk Remedies by Genus Artemisia Based on Ethnomedicinal Surveys and Traditional Knowledge of Native Communities of Pakistan. Pak J Bot (2013) 45:111-7.

40. Khan SW, Bot PJ, Wali Khan And S, Khatoon S. Ethnobotanical Studies on Some Useful Herbs of Haramosh and Bugrote Valleys in Gilgit. Northern Areas Pakistan (2008) 40:43-58.

41. Ding J, Wang L, He C, Zhao J, Si L, Huang H. Artemisia Scoparia: Traditional Uses, Active Constituents and Pharmacological Effects. J Ethnopharmacol (2021) 273:113960. doi: 10.1016/j.jep.2021.113960

42. Duah Boakye Y, Shaheen S, Nawaz H, Nisar S, Azeem MW. Artemisia Scoparia: A Review on Traditional Uses, Phytochemistry and Pharmacological Properties. IJCBS (2017) 12:92-7. 
43. Bensky D, Clavey S, Stoger E. Chinese Herbal Medicine: Materia Medica (Portable 3rd Ed.) - Eastland Press. 3rd Ed. Seattle, WA: Eastland Press (2015).

44. Hempen C-H. A Materia Medica for Chinese Medicine - 1st Edition. 1st Ed. London, UK: Churchill Livingstone (2009).

45. Hung HY, Kuo SC. Recent Studies and Progression of Yin Chen Hao (Yīn Chén Hāo), A Long-Term Used Traditional Chinese Medicine. J Tradit Complement Med (2013) 3:2-6. doi: 10.4103/2225-4110.106533

46. Tan XJ, Li Q, Chen XH, Wang ZW, Shi ZY, Bi KS, et al. Simultaneous Determination of 13 Bioactive Compounds in Herba Artemisiae Scopariae (Yin Chen) From Different Harvest Seasons by HPLC-DAD. J Pharm BioMed Anal (2008) 47:847-53. doi: 10.1016/j.jpba.2008.04.010

47. Sun X, Sun H, Zhang J, Ji X. Artemisia Extract Improves Insulin Sensitivity in Women With Gestational Diabetes Mellitus by Up-Regulating Adiponectin. J Clin Pharmacol (2016) 56:1550-4. doi: 10.1002/jcph.755

48. Richard AJ, Fuller S, Fedorcenco V, Beyl R, Burris TP, Mynatt R, et al. Artemisia Scoparia Enhances Adipocyte Development and Endocrine Function In Vitro and Enhances Insulin Action In Vivo. PloS One (2014) 9:e98897. doi: 10.1371/journal.pone.0098897

49. Richard AJ, Burris TP, Sanchez-Infantes D, Wang Y, Ribnicky DM, Stephens JM. Artemisia Extracts Activate Ppar $\gamma$, Promote Adipogenesis, and Enhance Insulin Sensitivity in Adipose Tissue of Obese Mice. Nutrition (2014) 30: S31-536. doi: 10.1016/j.nut.2014.02.013

50. Wang ZQ, Zhang XH, Yu Y, Tipton RC, Raskin I, Ribnicky D, et al. Artemisia Scoparia Extract Attenuates Non-Alcoholic Fatty Liver Disease in Diet-Induced Obesity Mice by Enhancing Hepatic Insulin and AMPK Signaling Independently of FGF21 Pathway. Metabolism (2013) 62:123949. doi: 10.1016/j.metabol.2013.03.004

51. Rood JC, Schwarz J-M, Gettys T, Mynatt RL, Mendoza T, Johnson WD, et al. Effects of Artemisia Species on De Novo Lipogenesis In Vivo. Nutrients (2014) 30:S17-20. doi: 10.1016/j.nut.2014.03.029

52. Harvey I, Stephens JM. Artemisia Scoparia Promotes Adipogenesis in the Absence of Adipogenic Effectors. Obesity (Silver Spring) (2021) 29(8):130919. doi: 10.1002/oby.23199

53. Yahagi T, Yakura N, Matsuzaki K, Kitanaka S. Inhibitory Effect of Chemical Constituents From Artemisia Scoparia Waldst. Et Kit. On Triglyceride Accumulation in 3T3-L1 Cells and Nitric Oxide Production in RAW 264.7 Cells. J Nat Med (2014) 68:414-20. doi: 10.1007/s11418-013-0799-3

54. Oh JH, Karadeniz F, Seo Y, Kong C-S. Artemisia Scoparia Inhibits Adipogenesis in 3T3-L1 Pre-Adipocytes by Downregulating the MAPK Pathway. J Life Sci (2018) 28:999-1006. doi: 10.5352/JLS.2018.28.9.999

55. Danforth E. Failure of Adipocyte Differentiation Causes Type II Diabetes Mellitus? Nat Genet (2000) 26:13-3. doi: 10.1038/79111

56. Hammarstedt A, Andersson CX, Rotter Sopasakis V, Smith U. The Effect of Ppary Ligands on the Adipose Tissue in Insulin Resistance. Prostaglandins Leukot Essent Fat Acids (2005) 73:65-75. doi: 10.1016/j.plefa.2005.04.008

57. Villarroel-Vicente C, Gutiérrez-Palomo S, Ferri J, Cortes D, Cabedo N. Natural Products and Analogs as Preventive Agents for Metabolic Syndrome via Peroxisome Proliferator-Activated Receptors: An Overview. Eur J Med Chem (2021) 221:113535. doi: 10.1016/j.ejmech.2021.113535

58. Duke CC, Tran VH, Duke RK, Abu-Mellal A, Plunkett GT, King DI, et al. A Sedge Plant as the Source of Kangaroo Island Propolis Rich in Prenylated PCoumarate Ester and Stilbenes. Phytochemistry (2017) 134:87-97. doi: 10.1016/j.phytochem.2016.11.005

59. Shafi S, Gupta P, Khatik GL, Gupta J. Ppary: Potential Therapeutic Target for Ailments Beyond Diabetes and Its Natural Agonism. Curr Drug Targets (2019) 20:1281-94. doi: 10.2174/1389450120666190527115538

60. Abdallah HM, Dine RSE, Mohamed GA, Ibrahim SRM, Shehata IA, ElHalawany AM. Natural Peroxisome Proliferator-Activated Receptor $\gamma$ (Ppary) Activators for Diabetes. Altern Ther Health Med (2020) 26:28-44.

61. Morigny P, Houssier M, Mouisel E, Langin D. Adipocyte Lipolysis and Insulin Resistance. Biochimie (2016) 125:259-66. doi: 10.1016/ j.biochi.2015.10.024

62. Boudreau A, Richard AJ, Burrell JA, King WT, Dunn R, Schwarz J-M, et al. An Ethanolic Extract of Artemisia Scoparia (SCO) Inhibits Lipolysis In Vivo and has Anti-Lipolytic Effects on Murine Adipocytes In Vitro. Am J Physiol Metab (2018) 315(5):E1053-61. doi: 10.1152/ajpendo.00177.2018
63. Choi E, Park H, Lee J, Kim G. Anticancer, Antiobesity, and AntiInflammatory Activity of Artemisia Species In Vitro. J Tradit Chin Med (2013) 33:92-7. doi: 10.1016/s0254-6272(13)60107-7

64. Gilani A ul H, Janbaz KH. Protective Effect of Artemisia Scoparia Extract Against Acetaminophen-Induced Hepatotoxicity. Gen Pharmacol (1993) 24:1455-8. doi: 10.1016/0306-3623(93)90434-Y

65. Gilani AH, Janbaz KH. Hepatoprotective Effects of Artemisia Scoparia Against Carbon Tetrachloride: An Environmental Contaminant. J Pak Med Assoc (1994) 44:65-8.

66. Engin A. The Pathogenesis of Obesity-Associated Adipose Tissue Inflammation. Adv Exp Med Biol (2017) 960:221-45. doi: 10.1007/978-3319-48382-5_9

67. Gustafson B, Hammarstedt A, Andersson CX, Smith U. Inflamed Adipose Tissue: A Culprit Underlying the Metabolic Syndrome and Atherosclerosis. Arterioscler Thromb Vasc Biol (2007) 27:2276-83. doi: 10.1161/ ATVBAHA.107.147835

68. Khan MA, Khan H, Tariq SA, Pervez S. In Vitro Attenuation of ThermalInduced Protein Denaturation by Aerial Parts of Artemisia Scoparia. J Evid Based Complement Altern Med (2015) 20:9-12. doi: 10.1177/ 2156587214548458

69. Ahn JH, Park YL, Song AY, Kim WG, Je CY, Jung DH, et al. Water Extract of Artemisia Scoparia Waldst. \& Kitam Suppresses LPS-Induced Cytokine Production and NLRP3 Inflammasome Activation in Macrophages and Alleviates Carrageenan-Induced Acute Inflammation in Mice. J Ethnopharmacol (2021) 268:113606. doi: 10.1016/j.jep.2020.113606

70. Habib M, Waheed I. Evaluation of Anti-Nociceptive, Anti-Inflammatory and Antipyretic Activities of Artemisia Scoparia Hydromethanolic Extract. J Ethnopharmacol (2013) 145:18-24. doi: 10.1016/J.JEP.2012.10.022

71. Ryu KJ, Yoou MS, Seo Y, Yoon KW, Kim HM, Jeong HJ. Therapeutic Effects of Artemisia Scoparia Waldst. Et Kitaib in a Murine Model of Atopic Dermatitis. Clin Exp Dermatol (2018) 43:798-805. doi: 10.1111/ced.13565

72. Boudreau A, Burke SJ, Collier JJ, Richard AJ, Ribnicky DM, Stephens JM. Mechanisms of Artemisia Scoparia 'S Anti-Inflammatory Activity in Cultured Adipocytes, Macrophages, and Pancreatic $\beta$-Cells. Obesity (2020) 28(9):1726-35. doi: 10.1002/oby.22912

73. Nam S-Y, Han N-R, Rah S-Y, Seo Y, Kim H-M, Jeong H-J. AntiInflammatory Effects of Artemisia Scoparia and Its Active Constituent, 3,5-Dicaffeoyl-Epi-Quinic Acid Against Activated Mast Cells. Immunopharmacol Immunotoxicol (2018) 40:52-8. doi: 10.1080/ 08923973.2017.1405438

74. Rudich A, Tlrosh A, Potashnik R, Hemi R, Kanety H, Bashan N. Prolonged Oxidative Stress Impairs Insulin-Induced GLUT4 Translocation in 3T3-L1 Adipocytes. Diabetes (1998) 47:1562-9. doi: 10.2337/diabetes.47.10.1562

75. Blair AS, Hajduch E, Litherland GJ, Hundal HS. Regulation of Glucose Transport and Glycogen Synthesis in L6 Muscle Cells During Oxidative Stress. Evidence for Cross-Talk Between the Insulin and SAPK2/p38 Mitogen-Activated Protein Kinase Signaling Pathways. J Biol Chem (1999) 274:36293-9. doi: 10.1074/jbc.274.51.36293

76. Frank GD, Eguchi S, Motley ED. The Role of Reactive Oxygen Species in Insulin Signaling in the Vasculature. Antioxid Redox Signal (2005) 7:105361. doi: $10.1089 /$ ars.2005.7.1053

77. Kim JS, Saengsirisuwan V, Sloniger JA, Teachey MK, Henriksen EJ. Oxidant Stress and Skeletal Muscle Glucose Transport: Roles of Insulin Signaling and P38 MAPK. Free Radic Biol Med (2006) 41:818-24. doi: 10.1016/ j.freeradbiomed.2006.05.031

78. Rains JL, Jain SK. Oxidative Stress, Insulin Signaling, and Diabetes. Free Radic Biol Med (2011) 50:567-75. doi: 10.1016/j.freeradbiomed.2010.12.006

79. Maddux BA, See W, Lawrence JC, Goldfine AL, Goldfine ID, Evans JL. Protection Against Oxidative Stress-Induced Insulin Resistance in Rat L6 Muscle Cells by Micromolar Concentrations of $\alpha$-Lipoic Acid. Diabetes (2001) 50:404-10. doi: 10.2337/diabetes.50.2.404

80. Yaribeygi H, Sathyapalan T, Atkin SL, Sahebkar A. Molecular Mechanisms Linking Oxidative Stress and Diabetes Mellitus. Oxid Med Cell Longev (2020) 2020:8609213. doi: 10.1155/2020/8609213

81. Gerber PA, Rutter GA. The Role of Oxidative Stress and Hypoxia in Pancreatic Beta-Cell Dysfunction in Diabetes Mellitus. Antioxid Redox Signal (2017) 26:501-18. doi: 10.1089/ars.2016.6755 
82. Singh HP, Mittal S, Kaur S, Batish DR, Kohli RK. Chemical Composition and Antioxidant Activity of Essential Oil From Residues of Artemisia Scoparia. Food Chem (2009) 114:642-5. doi: 10.1016/j.foodchem.2008.09.101

83. Afshar FH, Delazar A, Janneh O, Nazemiyeh H, Pasdaran A, Nahar L, et al. Evaluation of Antimalarial, Free-Radicalscavenging and Insecticidal Activities of Artemisia Scoparia and A. Spicigera, Asteraceae. Rev Bras Farmacogn (2011) 21:986-90. doi: 10.1590/S0102-695X2011005000144

84. Sajid M, Khan MR, Shah NA, Ullah S, Younis T, Majid M, et al. Proficiencies of Artemisia Scoparia Against CCl4 Induced DNA Damages and Renal Toxicity in Rat. BMC Complement Altern Med (2016) 16:149. doi: 10.1186/ s12906-016-1137-6

85. Khan K, Fatima H, Taqi MM, Zia M, ur-Rehman T, Mirza B, et al. Phytochemical and In Vitro Biological Evaluation of Artemisia Scoparia Waldst. \& Kit for Enhanced Extraction of Commercially Significant Bioactive Compounds. J Appl Res Med Aromat Plants (2015) 2:77-86. doi: 10.1016/j.jarmap.2015.04.002

86. Wicks S, Taylor CM, Luo M, Blanchard E, Ribnicky DM, Cefalu WT, et al. Artemisia Supplementation Differentially Affects the Mucosal and Luminal Ileal Microbiota of Diet-Induced Obese Mice. Nutrition (2014) 30:S26-30. doi: 10.1016/J.NUT.2014.02.007

87. Choi E, Kim G. Effect of Artemisia Species on Cellular Proliferation and Apoptosis in Human Breast Cancer Cells via Estrogen Receptor-Related Pathway. J Tradit Chin Med (2013) 33:658-63. doi: 10.1016/S0254-6272(14) 60038-8

88. Cho J-Y, Park K-H, Hwang D, Chanmuang S, Jaiswal L, Park Y-K, et al. Antihypertensive Effects of Artemisia Scoparia Waldst in Spontaneously Hypertensive Rats and Identification of Angiotensin I Converting Enzyme Inhibitors. Molecules (2015) 20:19789-804. doi: 10.3390/molecules201119657

89. Promyo K, Cho JY, Park KH, Jaiswal L, Park SY, Ham KS. Artemisia Scoparia Attenuates Amyloid $\beta$ Accumulation and Tau Hyperphosphorylation in Spontaneously Hypertensive Rats. Food Sci Biotechnol (2017) 26:775-82. doi: 10.1007/s10068-017-0077-3

90. Wang X, Huang H, Ma X, Wang L, Liu C, Hou B, et al. Anti-Inflammatory Effects and Mechanism of the Total Flavonoids From Artemisia Scoparia Waldst. Et Kit. In Vitro and In Vivo. BioMed Pharmacother (2018) 104:390403. doi: 10.1016/J.BIOPHA.2018.05.054

91. Singh HP, Kaur S, Mittal S, Batish DR, Kohli RK. In Vitro Screening of Essential Oil From Young and Mature Leaves of Artemisia Scoparia Compared to Its Major Constituents for Free Radical Scavenging Activity. Food Chem Toxicol (2010) 48:1040-4. doi: 10.1016/j.fct.2010.01.017

92. Cha J-D, Jeong M-R, Jeong S-I, Moon S-E, Kim J-Y, Kil B-S, et al. Chemical Composition and Antimicrobial Activity of the Essential Oils of Artemisia Scoparia and A. Capillaris. Planta Med (2005) 71:186-90. doi: 10.1055/s2005-837790

93. Yarnell E, Abascal K. Plant Coumarins: Myths and Realities. Altern Complement Ther (2009) 15:24-30. doi: 10.1089/act.2009.15104

94. Hassanein EHM, Sayed AM, Hussein OE, Mahmoud AM. Coumarins as Modulators of the Keap1/Nrf2/ARE Signaling Pathway. Oxid Med Cell Longev (2020) 2020:1675957. doi: 10.1155/2020/1675957

95. Garg SS, Gupta J, Sharma S, Sahu D. An Insight Into the Therapeutic Applications of Coumarin Compounds and Their Mechanisms of Action. Eur J Pharm Sci (2020) 152:105424. doi: 10.1016/j.ejps.2020.105424

96. Küpeli Akkol E, Genç Y, Karpuz B, Sobarzo-Sánchez E, Capasso R. Coumarins and Coumarin-Related Compounds in Pharmacotherapy of Cancer. Cancers (Basel) (2020) 12:1-25. doi: 10.3390/cancers12071959

97. Pinto DCGA, Silva AMS. Anticancer Natural Coumarins as Lead Compounds for the Discovery of New Drugs. Curr Top Med Chem (2017) 17(29):3190-8. doi: 10.2174/1568026618666171215095750

98. Yerer MB, Dayan S, Han MI, Sharma A, Tuli HS, Sak K. Nanoformulations of Coumarins and the Hybrid Molecules of Coumarins With Potential Anticancer Effects. Anticancer Agents Med Chem (2020) 20:1797-816. doi: 10.2174/1871520620666200310094646

99. Menezes JCJMDS, Diederich M. Translational Role of Natural Coumarins and Their Derivatives as Anticancer Agents. Future Med Chem (2019) 11:1057-82. doi: 10.4155/fmc-2018-0375

100. Shi W, Zhang J, Bao N, Guan F, Chen L, Sun J. Design, Synthesis, and Cytotoxic Evaluation of Novel Scopoletin Derivatives. Chem Biol Drug Des (2018) 91:641-6. doi: 10.1111/cbdd.13120
101. Khunnawutmanotham N, Chimnoi N, Saparpakorn P, Techasakul S. Synthesis and Anti-Acetylcholinesterase Activity of Scopoletin Derivatives. Bioorg Chem (2016) 65:137-45. doi: 10.1016/j.bioorg.2015.12.002

102. Nam SO, Park DH, Lee YH, Ryu JH, Lee YS. Synthesis of AminoalkylSubstituted Coumarin Derivatives as Acetylcholinesterase Inhibitors. Bioorg Med Chem (2014) 22:1262-7. doi: 10.1016/j.bmc.2014.01.010

103. Wang Z, Ling B, Zhang R, Liu Y. Docking and Molecular Dynamics Study on the Inhibitory Activity of Coumarins on Aldose Reductase. J Phys Chem B (2008) 112:10033-40. doi: 10.1021/jp8033227

104. Yuan C, Wang MH, Wang F, Chen PY, Ke XG, Yu B, et al. Network Pharmacology and Molecular Docking Reveal the Mechanism of Scopoletin Against Non-Small Cell Lung Cancer. Life Sci (2021) 270:119105. doi: 10.1016/j.lfs.2021.119105

105. Kim JK, Kim JY, Kim HJ, Park KG, Harris RA, Cho WJ, et al. Scoparone Exerts Anti-Tumor Activity Against DU145 Prostate Cancer Cells via Inhibition of STAT3 Activity. PloS One (2013) 8(11):e80391. doi: 10.1371/ journal.pone.0080391

106. Basu M, Mayana K, Xavier S, Balachandran S, Mishra N. Effect of Scopoletin on Monoamine Oxidases and Brain Amines. Neurochem Int (2016) 93:1137. doi: 10.1016/j.neuint.2016.01.001

107. Prajapati S, Tomar B, Srivastava A, Narkhede YB, Gaikwad AN, Lahiri A, et al. 6,7-Dihydroxycoumarin Ameliorates Crystal-Induced Necroptosis During Crystal Nephropathies by Inhibiting MLKL Phosphorylation. Life Sci (2021) 271:119193. doi: 10.1016/j.lfs.2021.119193

108. Tan DC, Idris KI, Kassim NK, Lim PC, Safinar Ismail I, Hamid M, et al. Comparative Study of the Antidiabetic Potential of Paederia Foetida Twig Extracts and Compounds From Two Different Locations in Malaysia. Pharm Biol (2019) 57:345-54. doi: 10.1080/13880209.2019.1610462

109. Rane AR, Paithankar H, Hosur RV, Choudhary S. Modulation of $\alpha$ Synuclein Fibrillation by Plant Metabolites, Daidzein, Fisetin and Scopoletin Under Physiological Conditions. Int J Biol Macromol (2021) 182:1278-91. doi: 10.1016/j.ijbiomac.2021.05.071

110. Kashyap P, Ram H, Shukla SD, Kumar S. Scopoletin: Antiamyloidogenic, Anticholinesterase, and Neuroprotective Potential of a Natural Compound Present in Argyreia Speciosa Roots by In Vitro and In Silico Study. Neurosci Insights (2020) 15:2633105520937693. doi: 10.1177/2633105520937693

111. Ali MY, Jannat S, Jung HA, Choi RJ, Roy A, Choi JS. Anti-Alzheimer's Disease Potential of Coumarins From Angelica Decursiva and Artemisia Capillaris and Structure-Activity Analysis. Asian Pac J Trop Med (2016) 9:103-11. doi: 10.1016/j.apjtm.2016.01.014

112. Yusufzai SK, Khan MS, Sulaiman O, Osman H, Lamjin DN. Molecular Docking Studies of Coumarin Hybrids as Potential Acetylcholinesterase, Butyrylcholinesterase, Monoamine Oxidase $\mathrm{a} / \mathrm{B}$ and $\beta$-Amyloid Inhibitors for Alzheimer's Disease. Chem Cent J (2018) 12:1-57. doi: 10.1186/s13065018-0497-z

113. Lin HC, Tsai SH, Chen CS, Chang YC, Lee CM, Lai ZY, et al. StructureActivity Relationship of Coumarin Derivatives on Xanthine OxidaseInhibiting and Free Radical-Scavenging Activities. Biochem Pharmacol (2008) 75:1416-25. doi: 10.1016/j.bcp.2007.11.023

114. Thuong PT, Hung TM, Ngoc TM, Ha DT, Min BS, Kwack SJ, et al. Antioxidant Activities of Coumarins From Korean Medicinal Plants and Their Structure-Activity Relationships. Phyther Res (2010) 24:101-6. doi: $10.1002 /$ ptr.2890

115. Kolodziej H, Kayser O, Woerdenbag HJ, van Uden W, Pras N. Structure Cytotoxicity Relationships of a Series of Natural and Semi-Synthetic Simple Coumarins as Assessed in Two Human Tumour Cell Lines. Z Fur Naturforsch - Sect C J Biosci (1997) 52:240-4. doi: 10.1515/znc-1997-3-416

116. Nurul Islam M, Jung HA, Sohn HS, Kim HM, Choi JS. Potent $\alpha$-Glucosidase and Protein Tyrosine Phosphatase 1B Inhibitors From Artemisia Capillaris. Arch Pharm Res (2013) 36:542-52. doi: 10.1007/s12272-013-0069-7

117. Al-Warhi T, Sabt A, Elkaeed EB, Eldehna WM. Recent Advancements of Coumarin-Based Anticancer Agents: An Up-to-Date Review. Bioorg Chem (2020) 103:104163. doi: 10.1016/j.bioorg.2020.104163

118. Sharma ML. Mechanism of Hypotensive Action of Scoparone. Indian J Med Res (1988) 87:387-94.

119. Thakur RS, Bagadia SC, Sharma ML. Hypotensive Activity of Some Dihydroxycoumarins and Their Congeners. Experientia (1978) 34:158-9. doi: $10.1007 / \mathrm{BF} 01944649$ 
120. Zutshi U, Rao PG, Soni A, Atal CK. Absorption, Distribution and Excretion of Scoparone: A Potent Hypotensive Agent. Indian J Exp Biol (1978) 16:836-8.

121. Hoult JRS, Payá M. Pharmacological and Biochemical Actions of Simple Coumarins: Natural Products With Therapeutic Potential. Gen Pharmacol (1996) 27:713-22. doi: 10.1016/0306-3623(95)02112-4

122. Huang HC, Lee CR, Weng YI, Lee MC, Lee YT. Vasodilator Effect of Scoparone (6,7-Dimethoxycoumarin) From a Chinese Herb. Eur J Pharmacol (1992) 218:123-8. doi: 10.1016/0014-2999(92)90155-W

123. Yamahara J, Kobayashi G, Matsuda H, Katayama T, Fujimura H. Vascular Dilatory Action of Artemisia Capillaris Bud Extracts and Their Active Constituent. J Ethnopharmacol (1989) 26:129-36. doi: 10.1016/0378-8741 (89)90060-3

124. Yamahara J, Kobayashi G, Matsuda H, Iwamoto M, Fujimura H. Vascular Dilatory Action of the Chinese Crude Drug. II. Effects of Scoparone on Calcium Mobilization. Chem Pharm Bull (1989) 37:485-9. doi: 10.1248/ cpb.37.485

125. Yamahara J, Kobayashi G, Matsuda H, Katayama T, Fujimura H. The Effect of Scoparone, a Coumarin Derivative Isolated From the Chinese Crude Drug Artemisiae Capillaris Flos, on the Heart. Chem Pharm Bull (1989) 37:1297-9. doi: 10.1248/cpb.37.1297

126. Cho DY, Ko HM, Kim J, Kim BW, Yun YS, Park JI, et al. Scoparone Inhibits LPS-Simulated Inflammatory Response by Suppressing IRF3 and ERK in BV-2 Microglial Cells. Molecules (2016) 21(12):1718. doi: 10.3390/ molecules 21121718

127. Fu B, Su Y, Ma X, Mu C, Yu F. Scoparone Attenuates Angiotensin II-Induced Extracellular Matrix Remodeling in Cardiac Fibroblasts. J Pharmacol Sci (2018) 137:110-5. doi: 10.1016/j.jphs.2018.05.006

128. Lyu L, Chen J, Wang W, Yan T, Lin J, Gao H, et al. Scoparone Alleviates Ang II-Induced Pathological Myocardial Hypertrophy in Mice by Inhibiting Oxidative Stress. J Cell Mol Med (2021) 25:3136-48. doi: 10.1111/ jcmm.16304

129. Wan C, Wei Y, Ma J, Geng X. Protective Effects of Scoparone Against Ischemia-Reperfusion-Induced Myocardial Injury. Mol Med Rep (2018) 18:1752-60. doi: 10.3892/mmr.2018.9123

130. Park S, Kim JK, Oh CJ, Choi SH, Jeon JH, Lee IK. Scoparone Interferes With STAT3-Induced Proliferation of Vascular Smooth Muscle Cells. Exp Mol Med (2015) 47(3):e145. doi: 10.1038/emm.2014.113

131. Jung SH, Lee GB, Ryu Y, Cui L, Lee HM, Kim J, et al. Inhibitory Effects of Scoparone From Chestnut Inner Shell on Platelet-Derived Growth FactorBB-Induced Vascular Smooth Muscle Cell Migration and Vascular Neointima Hyperplasia. J Sci Food Agric (2019) 99:4397-406. doi: 10.1002/ jsfa. 9674

132. Okada Y, Miyauchi N, Okuyama T, Suzuki K, Kobayashi T, Tsutsui C, et al. Search for Naturally Occurring Substances to Prevent the Complications of Diabetes. II. Inhibitory Effect of Coumarin and Flavonoid Derivatives on Bovine Lens Aldose Reductase and Rabbit Platelet Aggregation. Chem Pharm Bull (1995) 43:1385-7. doi: 10.1248/cpb.43.1385

133. Chen YL, Huang HC, Weng YI, Yu YJ, Lee YT. Morphological Evidence for the Antiatherogenic Effect of Scoparone in Hyperlipidaemic Diabetic Rabbits. Cardiovasc Res (1994) 28:1679-85. doi: 10.1093/cvr/28.11.1679

134. Huang H-C, Weng Y-I, Lee C-R, Jan T-R, Chen Y-L, Lee Y-T. Protection by Scoparone Against the Alterations of Plasma Lipoproteins, Vascular Morphology and Vascular Reactivity in Hyperlipidaemic Diabetic Rabbit. Br J Pharmacol (1993) 110:1508-14. doi: 10.1111/j.1476-5381.1993.tb13993.x

135. Noh JR, Kim YH, Hwang JH, Gang GT, Yeo SH, Kim KS, et al. Scoparone Inhibits Adipocyte Differentiation Through Down-Regulation of Peroxisome Proliferators-Activated Receptor $\gamma$ in 3T3-L1 Preadipocytes. Food Chem (2013) 141:723-30. doi: 10.1016/j.foodchem.2013.04.036

136. Wang Y, Wang M, Chen B, Shi J. Scoparone Attenuates High GlucoseInduced Extracellular Matrix Accumulation in Rat Mesangial Cells. Eur J Pharmacol (2017) 815:376-80. doi: 10.1016/j.ejphar.2017.09.039

137. Liu B, Deng X, Jiang Q, Li G, Zhang J, Zhang N, et al. Scoparone Alleviates Inflammation, Apoptosis and Fibrosis of Non-Alcoholic Steatohepatitis by Suppressing the TLR4/NF-Kb Signaling Pathway in Mice. Int Immunopharmacol (2019) 75:105797. doi: 10.1016/j.intimp.2019.105797

138. Liu B, Deng X, Jiang Q, Li G, Zhang J, Zhang N, et al. Scoparone Improves Hepatic Inflammation and Autophagy in Mice With Nonalcoholic Steatohepatitis by Regulating the ROS/P38/Nrf2 Axis and PI3K/AKT/
mTOR Pathway in Macrophages. BioMed Pharmacother (2020) 125:109895. doi: 10.1016/j.biopha.2020.109895

139. Murat Bilgin H, Atmaca M, Deniz Obay B, Özekinci S, Taşdemir E, Ketani A. Protective Effects of Coumarin and Coumarin Derivatives Against Carbon Tetrachloride-Induced Acute Hepatotoxicity in Rats. Exp Toxicol Pathol (2011) 63:325-30. doi: 10.1016/j.etp.2010.02.006

140. Atmaca M, Bilgin HM, Obay BD, Diken H, Kelle M, Kale E. The Hepatoprotective Effect of Coumarin and Coumarin Derivates on Carbon Tetrachloride-Induced Hepatic Injury by Antioxidative Activities in Rats. J Physiol Biochem (2011) 67:569-76. doi: 10.1007/s13105-011-0103-5

141. Zhang A, Sun H, Wang X. Urinary Metabolic Profiling of Rat Models Revealed Protective Function of Scoparone Against Alcohol Induced Hepatotoxicity. Sci Rep (2014) 4:6768. doi: 10.1038/srep06768

142. Huang W, Zhang J, Moore DD. A Traditional Herbal Medicine Enhances Bilirubin Clearance by Activating the Nuclear Receptor CAR. J Clin Invest (2004) 113:137-43. doi: 10.1172/jci18385

143. Dong B, Saha PK, Huang W, Chen W, Abu-Elheiga LA, Wakil SJ, et al. Activation of Nuclear Receptor CAR Ameliorates Diabetes and Fatty Liver Disease. Proc Natl Acad Sci USA (2009) 106:18831-6. doi: 10.1073/ pnas.0909731106

144. Gao J, He J, Zhai Y, Wada T, Xie W. The Constitutive Androstane Receptor Is an Anti-Obesity Nuclear Receptor That Improves in Sulin Sensitivity. J Biol Chem (2009) 284:25984-92. doi: 10.1074/jbc.M109.016808

145. Jiang M, Xie W. Role of the Constitutive Androstane Receptor in Obesity and Type 2 Diabetes: A Case Study of the Endobiotic Function of a Xenobiotic Receptor. Drug Metab Rev (2013) 45:156-63. doi: 10.3109/03602532. 2012.743561

146. Li X, Wang Z, Klaunig JE. Modulation of Xenobiotic Nuclear Receptors in High-Fat Diet Induced Non-Alcoholic Fatty Liver Disease. Toxicology (2018) 410:199-213. doi: 10.1016/J.TOX.2018.08.007

147. Juang SH, Hsieh MT, Hsu PL, Chen JL, Liu HK, Liang FP, et al. Studies of Coumarin Derivatives for Constitutive Androstane Receptor (CAR) Activation. Molecules (2020) 26(1):164. doi: 10.3390/molecules26010164

148. Jang SI, Kim Y-J, Lee W-Y, Kwak KC, Baek H, Beum Kwak G, et al. Scoparone From Artemisia Capillaris Inhibits the Release of Inflammatory Mediators in RAW 264,7 Cells Upon Stimulation Cells by Interferon-Y Plus LPS. Arch Pharm Res (2005) 28:203-8. doi: 10.1007/BF02977716

149. Jang S, Kim YJ, Kim HJ, Lee JC, Kim HY, Kim YC, et al. Scoparone Inhibits PMAInduced IL-8 and MCP-1 Production Through Suppression of NF- $\mathrm{kb}$ Activation in U937 Cells. Life Sci (2006) 78:2937-43. doi: 10.1016/j.lfs.2005.11.020

150. Niu N, Li B, Hu Y, Li X, Li J, Zhang H. Protective Effects of Scoparone Against Lipopolysaccharide-Induced Acute Lung Injury. Int Immunopharmacol (2014) 23:127-33. doi: 10.1016/j.intimp.2014.08.014

151. Witaicenis A, Seito LN, Da Silveira Chagas A, De Almeida LD, Luchini AC, Rodrigues-Orsi $\mathrm{P}$, et al. Antioxidant and Intestinal Anti-Inflammatory Effects of Plant-Derived Coumarin Derivatives. Phytomedicine (2014) 21:240-6. doi: 10.1016/j.phymed.2013.09.001

152. Xia J, Li CY, Wang H, Zhang QM, Han ZM. Therapeutic Effects of Scoparone on Pilocarpine (Pilo)-Induced Seizures in Mice. BioMed Pharmacother (2018) 97:1501-13. doi: 10.1016/j.biopha.2017.09.127

153. Sourivong $\mathrm{P}$, Schronerová $\mathrm{K}$, Babincová $\mathrm{M}$. Scoparone Inhibits Ultraviolet Radiation-Induced Lipid Peroxidation. Z Fur Naturforsch - Sect C J Biosci (2007) 62:61-4. doi: 10.1515/znc-2007-1-211

154. Noh JR, Gang GT, Kim YH, Yang KJ, Hwang JH, Lee HS, et al. Antioxidant Effects of the Chestnut (Castanea Crenata) Inner Shell Extract in T-BHPTreated HepG2 Cells, and CCl4- and High-Fat Diet-Treated Mice. Food Chem Toxicol (2010) 48:3177-83. doi: 10.1016/j.fct.2010.08.018

155. Noh JR, Kim YH, Gang GT, Hwang JH, Lee HS, Ly SY, et al. Hepatoprotective Effects of Chestnut (Castanea Crenata) Inner Shell Extract Against Chronic Ethanol-Induced Oxidative Stress in C57BL/6 Mice. Food Chem Toxicol (2011) 49:1537-43. doi: 10.1016/j.fct.2011.03.045

156. Liu SJ, Zhou SW. 6,7-Dimethoxycoumarin Attenuated Cisplatin-Induced DNA Interstrand Crosslink and DNA-Protein Crosslink in Primary Cultured Rabbit Kidney Proximal Tubular Cells. Acta Pharmacol Sin (1999) 20:391-4.

157. Xu M, Cai J, Wei H, Zhou M, Xu P, Huang H, et al. Scoparone Protects Against Pancreatic Fibrosis via TGF- $\beta /$ Smad Signaling in Rats. Cell Physiol Biochem (2016) 40:277-86. doi: 10.1159/000452544 
158. Lee SH, Jang HD. Scoparone Attenuates RANKL-Induced Osteoclastic Differentiation Through Controlling Reactive Oxygen Species Production and Scavenging. Exp Cell Res (2015) 331:267-77. doi: 10.1016/j.yexcr. 2014.12.018

159. Huei-Chen H, Shu-Hsun C, Lee Chao P-D. Vasorelaxants From Chinese Herbs, Emodin and Scoparone, Possess Immunosuppressive Properties. Eur J Pharmacol (1991) 198:211-3. doi: 10.1016/0014-2999(91)90624-Y

160. Choi YH, Yan GH. Anti-Allergic Effects of Scoparone on Mast CellMediated Allergy Model. Phytomedicine (2009) 16:1089-94. doi: 10.1016/ j.phymed.2009.05.003

161. Yang YJ, Lee HJ, Choi DH, Huang HS, Lim SC, Lee MK. Effect of Scoparone on Neurite Outgrowth in PC12 Cells. Neurosci Lett (2008) 440:14-8. doi: 10.1016/j.neulet.2008.05.051

162. Yang YJ, Lee HJ, Lee BK, Lim SC, Lee CK, Lee MK. Effects of Scoparone on Dopamine Release in PC12 Cells. Fitoterapia (2010) 81:497-502. doi: $10.1016 /$ j.fitote.2010.01.003

163. Yang YJ, Lee HJ, Huang HS, Lee BK, Choi HS, Lim SC, et al. Effects of Scoparone on Dopamine Biosynthesis and L-DOPA-Induced Cytotoxicity in PC12 Cells. J Neurosci Res (2009) 87:1929-37. doi: 10.1002/jnr.22009

164. Kiełbus M, Skalicka-Woźniak K, Grabarska A, Jeleniewicz W, DmoszyńskaGraniczka M, Marston A, et al. 7-Substituted Coumarins Inhibit Proliferation and Migration of Laryngeal Cancer Cells In Vitro. Anticancer Res (2013) 33:4347-56.

165. Céspedes CL, Avila JG, Martínez A, Serrato B, Calderón-Mugica JC, SalgadoGarciglia R. Antifungal and Antibacterial Activities of Mexican Tarragon (Tagetes Lucida). J Agric Food Chem (2006) 54:3521-7. doi: 10.1021/ jf053071w

166. Yang B, Chen G, Song X, Chen Z, Song X, Wang J. Chemical Constituents and Antimicrobial Activities of Canthium Horridum. Nat Prod Commun (2010) 5:913-4. doi: 10.1177/1934578x1000500620

167. Vila-Nova NS, de Morais SM, Falcão MJC, Alcantara TTN, Ferreira PAT, Cavalcanti ESB, et al. Different Susceptibilities of Leishmania Spp. Promastigotes to the Annona Muricata Acetogenins Annonacinone and Corossolone, and the Platymiscium Floribundum Coumarin Scoparone. Exp Parasitol (2013) 133:334-8. doi: 10.1016/j.exppara.2012.11.025

168. Xu LN, Na WL, Liu X, Hou SG, Lin S, Yang H, et al. Identification of Natural Coumarin Compounds That Rescue Defective $\Delta$ f508-CFTR Chloride Channel Gating. Clin Exp Pharmacol Physiol (2008) 35:878-83. doi: 10.1111/j.1440-1681.2008.04943.x

169. Yang H, Xu LN, Liu X, He CY, Fang RY, Liu J, et al. Stimulation of Airway and Intestinal Mucosal Secretion by Natural Coumarin CFTR Activators. Front Pharmacol (2011) 52:52. doi: 10.3389/fphar.2011.00052

170. Yang D, Yang J, Shi D, Deng R, Yan B. Scoparone Potentiates Transactivation of the Bile Salt Export Pump Gene and This Effect Is Enhanced by Cytochrome P450 Metabolism But Abolished by a PKC Inhibitor. Br J Pharmacol (2011) 164:1547-57. doi: 10.1111/j.14765381.2011.01522.x

171. Taşdemir E, Atmaca M, Ylldlrlm Y, Bilgin HM, Demirtaş B, Obay BD, et al. Influence of Coumarin and Some Coumarin Derivatives on Serum Lipid Profiles in Carbontetrachloride-Exposed Rats. Hum Exp Toxicol (2017) 36:295-301. doi: 10.1177/0960327116649675

172. Liu X, Zhao X. Scoparone Attenuates Hepatic Stellate Cell Activation Through Inhibiting TGF- $\beta /$ Smad Signaling Pathway. BioMed Pharmacother (2017) 93:57-61. doi: 10.1016/j.biopha.2017.06.006

173. Hui Y, Wang X, Yu Z, Fan X, Cui B, Zhao T, et al. Scoparone as a Therapeutic Drug in Liver Diseases: Pharmacology, Pharmacokinetics and Molecular Mechanisms of Action. Pharmacol Res (2020) 160:105170. doi: 10.1016/ j.phrs.2020.105170

174. Gao Y, Xi B, Li J, Li Z, Xu J, Zhong M, et al. Scoparone Alleviates Hepatic Fibrosis by Inhibiting the TLR-4/NF-kb Pathway. J Cell Physiol (2021) 236:3044-58. doi: 10.1002/jcp.30083

175. Ivanovska N, Yossifova T, Vassileva E, Kostova I. Effect of Some Hydroxycoumarins on Complement-Mediated Hemolysis in Human Serum. Methods Find Exp Clin Pharmacol (1994) 16:557-62.

176. Lu C, Li Y, Hu S, Cai Y, Yang Z, Peng K. Scoparone Prevents IL-1 1 -Induced Inflammatory Response in Human Osteoarthritis Chondrocytes Through the PI3K/Akt/NF-Kb Pathway. BioMed Pharmacother (2018) 106:1169-74. doi: 10.1016/j.biopha.2018.07.062
177. Choi BR, Kim HK, Park JK. Penile Erection Induced by Scoparone From Artemisia Capillaris Through the Nitric Oxide-Cyclic Guanosine Monophosphate Signaling Pathway. World J Mens Health (2017) 35:196. doi: $10.5534 /$ wjmh. 17023

178. Yang JY, Koo JH, Song YG, Kwon KB, Lee JH, Sohn HS, et al. Stimulation of Melanogenesis by Scoparone in B16 Melanoma Cells. Acta Pharmacol Sin (2006) 27:1467-73. doi: 10.1111/j.1745-7254.2006.00435.x

179. Lee SH, Lee JY, Kwon YI, Jang HD. Anti-Osteoclastic Activity of Artemisia Capillaris Thunb. Extract Depends Upon Attenuation of Osteoclast Differentiation and Bone Resorption-Associated Acidification Due to Chlorogenic Acid, Hyperoside, and Scoparone. Int J Mol Sci (2017) 18 (2):322. doi: 10.3390/ijms 18020322

180. Jung HA, Park JJ, Islam MN, Jin SE, Min B-S, Lee J-H, et al. Inhibitory Activity of Coumarins From Artemisia Capillaris Against Advanced Glycation Endproduct Formation. Arch Pharm Res (2012) 35:1021-35. doi: 10.1007/s12272-012-0610-0

181. Lee HI, Lee MK. Coordinated Regulation of Scopoletin at Adipose TissueLiver Axis Improved Alcohol-Induced Lipid Dysmetabolism and Inflammation in Rats. Toxicol Lett (2015) 237:210-8. doi: 10.1016/ j.toxlet.2015.06.016

182. Lee HI, Yun KW, Seo K, Kim MJ, Lee MK. Scopoletin Prevents AlcoholInduced Hepatic Lipid Accumulation by Modulating the AMPK-SREBP Pathway in Diet-Induced Obese Mice. Metabolism (2014) 63:593-601. doi: 10.1016/j.metabol.2014.01.003

183. Choi RY, Ham JR, Lee HI, Cho HW, Choi MS, Park SK, et al. Scopoletin Supplementation Ameliorates Steatosis and Inflammation in Diabetic Mice. Phyther Res (2017) 31:1795-804. doi: 10.1002/ptr.5925

184. Chang WC, Wu SC, Xu KD, Liao BC, Wu JF, Cheng AS. Scopoletin Protects Against Methylglyoxal-Induced Hyperglycemia and Insulin Resistance Mediated by Suppression of Advanced Glycation Endproducts (AGEs) Generation and Anti-Glycation. Molecules (2015) 20:2786-801. doi: $10.3390 /$ molecules 20022786

185. Kalpana K, Priyadarshini E, Sreeja S, Jagan K, Anuradha CV. Scopoletin Intervention in Pancreatic Endoplasmic Reticulum Stress Induced by Lipotoxicity. Cell Stress Chaperones (2018) 23:857-69. doi: 10.1007/s12192018-0893-2

186. Kalpana K, Sathiya Priya C, Dipti N, Vidhya R, Anuradha CV. Supplementation of Scopoletin Improves Insulin Sensitivity by Attenuating the Derangements of Insulin Signaling Through AMPK. Mol Cell Biochem (2019) 453:65-78. doi: 10.1007/s11010-018-3432-7

187. Jang JH, Park JE, Han JS. Scopoletin Inhibits $\alpha$-Glucosidase In Vitro and Alleviates Postprandial Hyperglycemia in Mice With Diabetes. Eur J Pharmacol (2018) 834:152-6. doi: 10.1016/j.ejphar.2018.07.032

188. Zhang WY, Lee JJ, Kim Y, Kim IS, Park JS, Myung CS. Amelioration of Insulin Resistance by Scopoletin in High-Glucose-Induced, Insulin-Resistant HepG2 Cells. Horm Metab Res (2010) 42:930-5. doi: 10.1055/s-00301265219

189. Kim J, Kim CS, Lee YM, Sohn E, Jo K, Shin SD, et al. Scopoletin Inhibits Rat Aldose Reductase Activity and Cataractogenesis in Galactose-Fed Rats. Evidence-Based Complement Altern Med (2013) 2013:787138. doi: 10.1155/ 2013/787138

190. Lee J, Kim NH, Nam JW, Lee YM, Jang DS, Kim YS, et al. Scopoletin From the Flower Buds of Magnolia Fargesii Inhibits Protein Glycation, Aldose Reductase, and Cataractogenesis Ex Vivo. Arch Pharm Res (2010) 33:131723. doi: 10.1007/s12272-010-0904-z

191. Ojewole JAO, Adesina SK. Cardiovascular and Neuromuscular Actions of Scopoletin From Fruit of Tetrapleura Tetrapetra. Planta Med (1983) 49:99102. doi: $10.1055 / \mathrm{s}-2007-969824$

192. Lagunas-Herrera H, Tortoriello J, Herrera-Ruiz M, Martínez-Henández GB, Zamilpa A, Santamaría LA, et al. Acute and Chronic Antihypertensive Effect of Fractions, Tiliroside and Scopoletin From Malva Parviflora. Biol Pharm Bull (2019) 42:18-25. doi: 10.1248/bpb.b18-00355

193. Ojewole JAO, Adesina SK. Mechanism of the Hypotensive Effect of Scopoletin Isolated From the Fruit of Tetrapleura Tetraptera. Planta Med (1983) 49:46-50. doi: 10.1055/s-2007-969809

194. Thuong PT, Na M, Su ND, Seong RS, Lee YM, Sok DE, et al. Inhibitory Effect of Coumarins From Weigela Subsessilis on Low Density Lipoprotein Oxidation. Biol Pharm Bull (2005) 28:1095-7. doi: 10.1248/bpb.28.1095 
195. Yang JY, Koo JH, Yoon HY, Lee JH, Park BH, Kim JS, et al. Effect of Scopoletin on Lipoprotein Lipase Activity in 3T3-L1 Adipocytes. Int J Mol Med (2007) 20:527-31. doi: 10.3892/ijmm.20.4.527

196. Park SH, Sung YY, Nho KJ, Kim DS, Kim HK. E Effects of Viola Mandshurica on Atherosclerosis and Hepatic Steatosis in ApoE-/- via the AMPK Pathway. Am J Chin Med (2017) 45:757-72. doi: 10.1142/S0192415X17500409

197. Oliveira EJ, Romero MA, Silva MS, Silva BA, Medeiros IA. Intracellular Calcium Mobilization as a Target for the Spasmolytic Action of Scopoletin. Planta Med (2001) 67:605-8. doi: 10.1055/s-2001-17355

198. Iizuka T, Nagumo S, Yotsumoto H, Moriyama H, Nagai M. Vasorelaxant Effects of Acer Nikoense Extract and Isolated Coumarinolignans on Rat Aortic Rings. Biol Pharm Bull (2007) 30:1164-6. doi: 10.1248/bpb.30.1164

199. Pan R, Dai Y, Gao XH, Lu D, Xia YF. Inhibition of Vascular Endothelial Growth Factor-Induced Angiogenesis by Scopoletin Through Interrupting the Autophosphorylation of VEGF Receptor 2 and Its Downstream Signaling Pathways. Vascul Pharmacol (2011) 54:18-28. doi: 10.1016/j.vph.2010. 11.001

200. Kang SY, Sung SH, Park JH, Kim YC. Hepatoprotective Activity of Scopoletin, a Constituent of Solanum Lyratum. Arch Pharm Res (1998) 21:718-22. doi: 10.1007/BF02976764

201. Zeng Y, Ma Y, Yang Z, Mao J, Zheng Y. Antihyperuricemic Efficacy of Scopoletin-Loaded Soluplus Micelles in Yeast Extract/Potassium OxonateInduced Hyperuricemic Mice. Drug Dev Ind Pharm (2020) 46:1550-7. doi: 10.1080/03639045.2020.1811302

202. Ding Z, Dai Y, Wang Z. Hypouricemic Action of Scopoletin Arising From Xanthine Oxidase Inhibition and Uricosuric Activity. Planta Med (2005) 71:183-5. doi: 10.1055/s-2005-837789

203. Tang WM, Chan E, Kwok CY, Lee YK, Wu JH, Wan CW, et al. A Review of the Anticancer and Immunomodulatory Effects of Lycium Barbarum Fruit. Inflammopharmacology (2012) 20:307-14. doi: 10.1007/s10787-011-0107-3

204. Xue M, Tian Q, Wang L, Sun X, Zeng F, Pan Q. Scopoletin Exerts Anticancer Effects on Human Cervical Cancer Cell Lines by Triggering Apoptosis, Cell Cycle Arrest, Inhibition of Cell Invasion and PI3K/AKT Signalling Pathway. JBUON (2019) 24:997-1002.

205. Adams M, Efferth T, Bauer R. Activity-Guided Isolation of Scopoletin and Isoscopoletin, the Inhibitory Active Principles Towards CCRF-CEM Leukaemia Cells and Multi-Drug Resistant CEM/ADR5000 Cells, From Artemisia Argyi. Planta Med (2006) 72:862-4. doi: 10.1055/s-2006-947165

206. Cassady JM, Ojima N, Chang CJ, McLaughlin JL. An Investigation of the Antitumor Activity of Micromelum Integerrimum (Rutaceae). J Nat Prod (1979) 42:274-8. doi: 10.1021/np50003a005

207. Barreiro Arcos ML, Cremaschi G, Werner S, Coussio J, Ferraro G, Anesini C. Tilia Cordata Mill. Extracts and Scopoletin (Isolated Compound): Differential Cell Growth Effects on Lymphocytes. Phyther Res (2006) 20:34-40. doi: 10.1002/ptr.1798

208. Manuele MG, Ferraro G, Barreiro Arcos ML, López P, Cremaschi G, Anesini C. Comparative Immunomodulatory Effect of Scopoletin on Tumoral and Normal Lymphocytes. Life Sci (2006) 79:2043-8. doi: 10.1016/ j.lfs.2006.06.045

209. Bhattacharyya SS, Paul S, Dutta S, Boujedaini N, Khuda-Bukhsh AR. AntiOncogenic Potentials of a Plant Coumarin (7-Hydroxy-6-Methoxy Coumarin) Against 7,12-Dimethylbenz[a]Anthracene-Induced Skin Papilloma in Mice: The Possible Role of Several Key Signal Proteins. J Chin Integr Med (2010) 8:645-54. doi: 10.3736/jcim20100708

210. Khuda-Bukhsh AR, Bhattacharyya SS, Paul S, Boujedaini N. Polymeric Nanoparticle Encapsulation of a Naturally Occurring Plant Scopoletin and Its Effects on Human Melanoma Cell A375. J Chin Integr Med (2010) 8:85362. doi: 10.3736/jcim20100909

211. Tabana YM, Hassan LEA, Ahamed MBK, Dahham SS, Iqbal MA, Saeed MAA, et al. Scopoletin, an Active Principle of Tree Tobacco (Nicotiana Glauca) Inhibits Human Tumor Vascularization in Xenograft Models and Modulates ERK1, VEGF-A, and FGF-2 in Computer Model. Microvasc Res (2016) 107:17-33. doi: 10.1016/j.mvr.2016.04.009

212. Sheng L, Yang Y, Zhang Y, Li N. Chemical Constituents of Patrinia Heterophylla Bunge and Selective Cytotoxicity Against Six Human Tumor Cells. J Ethnopharmacol (2019) 236:129-35. doi: 10.1016/j.jep.2019.03.005

213. Khunluck T, Kukongviriyapan V, Senggunprai L, Duangarsong W, Prawan A. The Inhibition Kinetics and Potential Anti-Migration Activity of NQO1
Inhibitory Coumarins on Cholangiocarcinoma Cells. Integr Cancer Ther (2019) 18:1534735418820444. doi: 10.1177/1534735418820444

214. Deng S, Palu AK, West BJ, Su CX, Zhou BN, Jensen JC. Lipoxygenase Inhibitory Constituents of the Fruits of Noni (Morinda Citrifolia) Collected in Tahiti. J Nat Prod (2007) 70:859-62. doi: 10.1021/np0605539

215. Pan R, Gao XH, Li Y, Xia YF, Dai Y. Anti-Arthritic Effect of Scopoletin, a Coumarin Compound Occurring in Erycibe Obtusifolia Benth Stems, Is Associated With Decreased Angiogenesis in Synovium. Fundam Clin Pharmacol (2010) 24:477-90. doi: 10.1111/j.1472-8206.2009.00784.x

216. Shaw CY, Chen CH, Hsu CC, Chen CC, Tsai YC. Antioxidant Properties of Scopoletin Isolated From Sinomonium Acutum. Phyther Res (2003) 17:823-5. doi: 10.1002/ptr.1170

217. Kim AR, Zou YN, Park TH, Shim KH, Kim MS, Kim ND, et al. Active Components From Artemisia Iwayomogi Displaying ONOO- Scavenging Activity. Phyther Res (2004) 18:1-7. doi: 10.1002/ptr.1358

218. Abreu PM, Matthew S, González T, Vanickova L, Costa D, Gomes A, et al. Isolation and Identification of Antioxidants From Pedilanthus Tithymaloides. J Nat Med (2008) 62:67-70. doi: 10.1007/s11418-007-0186-Z

219. Khan S, Riaz N, Afza N, Malik A, Aziz-Ur-Rehmana, Iqbal L, et al. Antioxidant Constituents From Cotoneaster Racemiflora. J Asian Nat Prod Res (2009) 11:44-8. doi: 10.1080/10286020802435745

220. DellaGreca M, Cutillo F, D’Abrosca B, Fiorentino A, Pacifico S, Zarrelli A. Antioxidant and Radical Scavenging Properties of Malva Sylvestris. Nat Prod Commun (2009) 4:893-6. doi: 10.1177/1934578x0900400702

221. Kassim NK, Rahmani M, Ismail A, Sukari MA, Ee GCL, Nasir NM, et al. Antioxidant Activity-Guided Separation of Coumarins and Lignan From Melicope Glabra (Rutaceae). Food Chem (2013) 139:87-92. doi: 10.1016/ j.foodchem.2013.01.108

222. Nugroho A, Lim SC, Karki S, Choi JS, Park HJ. Simultaneous Quantification and Validation of New Peroxynitrite Scavengers From Artemisia Iwayomogi. Pharm Biol (2015) 53:653-61. doi: 10.3109/13880209.2014.936022

223. Parra C, Soto E, León G, Salas CO, Heinrich M, Echiburú-Chau C. Nutritional Composition, Antioxidant Activity and Isolation of Scopoletin From Senecio Nutans: Support of Ancestral and New Uses. Nat Prod Res (2018) 32:719-22. doi: 10.1080/14786419.2017.1335726

224. Panda S, Kar A. Evaluation of the Antithyroid, Antioxidative and Antihyperglycemic Activity of Scopoletin From Aegle Marmelos Leaves in Hyperthyroid Rats. Phyther Res (2006) 20:1103-5. doi: 10.1002/ptr.2014

225. Ng TB, Liu F, Lu Y, Cheng CHK, Wang Z. Antioxidant Activity of Compounds From the Medicinal Herb Aster Tataricus. Comp Biochem Physiol - C Toxicol Pharmacol (2003) 136:109-15. doi: 10.1016/S1532-0456 (03)00170-4

226. Toda S. Inhibitory Effects of Phenylpropanoid Metabolites on CopperInduced Protein Oxidative Modification of Mice Brain Homogenate In Vitro. Biol Trace Elem Res (2002) 85:183-8. doi: 10.1385/BTER:85:2:183

227. Pradhan P, Majhi O, Biswas A, Joshi VK, Sinha D. Enhanced Accumulation of Reduced Glutathione by Scopoletin Improves Survivability of Dopaminergic Neurons in Parkinson's Model. Cell Death Dis (2020) 11:111. doi: 10.1038/s41419-020-02942-8

228. Silván AM, Abad MJ, Bermejo P, Sollhuber M, Villar A. Antiinflammatory Activity of Coumarins From Santolina Oblongifolia. J Nat Prod (1996) 59:1183-5. doi: 10.1021/np960422f

229. Silvan AM, Abad MJ, Bermejo P, Villar A. Effects of Compounds Extracted From Santolina Oblongifolia on TXB2 Release in Human Platelets. Inflammopharmacology (1998) 6:255-63. doi: 10.1007/s10787-998-0024-2

230. Kang TH, Pae HO, Jeong SJ, Yoo JC, Choi BM, Jun CD, et al. Scopoletin: An Inducible Nitric Oxide Synthesis Inhibitory Active Constituent From Artemisia Feddei. Planta Med (1999) 65:400-3. doi: 10.1055/s-1999-14014

231. Kim HJ, Jang S, Kim YJ, Chung HT, Yun YG, Kang TH, et al. Scopoletin Suppresses Pro-Inflammatory Cytokines and PGE2 From LPS-Stimulated Cell Line, RAW 264.7 Cells. Fitoterapia (2004) 75:261-6. doi: 10.1016/ j.fitote.2003.12.021

232. Kim JS, Jin CK, Sang HS, Eun JL, Jin WY, Bae KH, et al. Chemical Constituents of the Root of Dystaenia Takeshimana and Their AntiInflammatory Activity. Arch Pharm Res (2006) 29:617-23. doi: 10.1007/ BF02968244

233. Moon PD, Lee BH, Jeong HJ, An HJ, Park SJ, Kim HR, et al. Use of Scopoletin to Inhibit the Production of Inflammatory Cytokines Through 


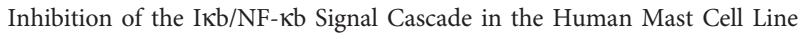
HMC-1. Eur J Pharmacol (2007) 555:218-25. doi: 10.1016/ j.ejphar.2006.10.021

234. Choi YG, Yeo S, Kim SH, Lim S. Anti-Inflammatory Changes of Gene Expression by Artemisia Iwayomogi in the LPS-Stimulated Human Gingival Fibroblast: Microarray Analysis. Arch Pharm Res (2012) 35:549-63. doi: 10.1007/s12272-012-0319-0

235. Dou Y, Tong B, Wei Z, Li Y, Xia Y, Dai Y. Scopoletin Suppresses IL-6 Production From Fibroblast-Like Synoviocytes of Adjuvant Arthritis Rats Induced by IL-1 $\beta$ Stimulation. Int Immunopharmacol (2013) 17:1037-43. doi: 10.1016/j.intimp.2013.10.011

236. Kamino T, Shimokura T, Morita Y, Tezuka Y, Nishizawa M, Tanaka K. Comparative Analysis of the Constituents in Saposhnikoviae Radix and Glehniae Radix Cum Rhizoma by Monitoring Inhibitory Activity of Nitric Oxide Production. J Nat Med (2016) 70:253-9. doi: 10.1007/s11418-016-0969-1

237. Yao X, Ding Z, Xia Y, Wei Z, Luo Y, Feleder C, et al. Inhibition of Monosodium Urate Crystal-Induced Inflammation by Scopoletin and Underlying Mechanisms. Int Immunopharmacol (2012) 14:454-62. doi: 10.1016/j.intimp.2012.07.024

238. Muschietti L, Gorzalczany S, Ferraro G, Acevedo C, Martino V. Phenolic Compounds With Anti-Inflammatory Activity From Eupatorium Buniifolium. Planta Med (2001) 67:743-4. doi: 10.1055/s-2001-18355

239. Farah MH, Samuelsson G. Pharmacologically Active Phenylpropanoids From Senra Incana. Planta Med (1992) 58:14-8. doi: 10.1055/s-2006-961380

240. Chang TN, Deng JS, Chang YC, Lee CY, Jung-Chun L, Lee MM, et al. Ameliorative Effects of Scopoletin From Crossostephium Chinensis Against Inflammation Pain and Its Mechanisms in Mice. Evidence-Based Complement Altern Med (2012) 2012:595603. doi: 10.1155/2012/595603

241. Pereira dos Santos Nascimento MV, Arruda-Silva F, Gobbo Luz AB, Baratto B, Venzke D, Mendes BG, et al. Inhibition of the NF- $\mathrm{kb}$ and P38 MAPK Pathways by Scopoletin Reduce the Inflammation Caused by Carrageenan in the Mouse Model of Pleurisy. Immunopharmacol Immunotoxicol (2016) 38:344-52. doi: 10.1080/08923973.2016.1203929

242. Ribas CM, Meotti FC, Nascimento FP, Jacques AV, Dafre AL, Rodrigues ALS, et al. Antinociceptive Effect of the Polygala Sabulosa Hydroalcoholic Extract in Mice: Evidence for the Involvement of Glutamatergic Receptors and Cytokine Pathways. Basic Clin Pharmacol Toxicol (2008) 103:43-7. doi: $10.1111 / j .1742-7843.2008 .00245 . x$

243. Sakthivel KM, Vishnupriya S, Priya Dharshini LC, Rasmi RR, Ramesh B. Modulation of Multiple Cellular Signalling Pathways as Targets for AntiInflammatory and Anti-Tumorigenesis Action of Scopoletin. J Pharm Pharmacol (2021) 13:rgab047. doi: 10.1093/jpp/rgab047

244. Mahattanadul S, Ridtitid W, Nima S, Phdoongsombut N, Ratanasuwon P, Kasiwong S. Effects of Morinda Citrifolia Aqueous Fruit Extract and Its Biomarker Scopoletin on Reflux Esophagitis and Gastric Ulcer in Rats. J Ethnopharmacol (2011) 134:243-50. doi: 10.1016/j.jep.2010.12.004

245. Ding Z, Dai Y, Hao H, Pan R, Yao X, Wang Z. Anti-Inflammatory Effects of Scopoletin and Underlying Mechanisms. Pharm Biol (2008) 46:854-60. doi: $10.1080 / 13880200802367155$

246. Capra JC, Cunha MP, Machado DG, Zomkowski ADE, Mendes BG, Santos ARS, et al. Antidepressant-Like Effect of Scopoletin, a Coumarin Isolated From Polygala Sabulosa (Polygalaceae) in Mice: Evidence for the Involvement of Monoaminergic Systems. Eur J Pharmacol (2010) 643:2328. doi: 10.1016/j.ejphar.2010.06.043

247. Mogana R, Teng-Jin K, Wiart C. Anti-Inflammatory, Anticholinesterase, and Antioxidant Potential of Scopoletin Isolated From Canarium Patentinervium Miq. (Burseraceae Kunth). Evidence-Based Complement Altern Med (2013) 2013:734824. doi: 10.1155/2013/734824

248. Narasimhan KKS, Jayakumar D, Velusamy P, Srinivasan A, Mohan T, Ravi DB, et al. Morinda Citrifolia and Its Active Principle Scopoletin Mitigate Protein Aggregation and Neuronal Apoptosis Through Augmenting the DJ1/Nrf2/ARE Signaling Pathway. Oxid Med Cell Longev (2019) 2019:2761041. doi: 10.1155/2019/2761041

249. Lee B, Weon J, Eom M, Jung Y, Ma C. Neuroprotective Compounds of Tilia Amurensis. Pharmacogn Mag (2015) 11:303. doi: 10.4103/0973-1296.166065

250. Yun BS, Lee IK, Ryoo IJ, Yoo ID. Coumarins With Monoamine Oxidase Inhibitory Activity and Antioxidative Coumarino-Lignans From Hibiscus Syriacus. J Nat Prod (2001) 64:1238-40. doi: 10.1021/np0100946
251. Zhang F, Zhang Y, Yang T, Ye ZQ, Tian J, Fang HR, et al. Scopoletin Suppresses Activation of Dendritic Cells and Pathogenesis of Experimental Autoimmune Encephalomyelitis by Inhibiting NF- kb Signaling. Front Pharmacol (2019) 10:863. doi: 10.3389/fphar.2019.00863

252. Luo L, Sun T, Yang L, Liu A, Liu QQ, Tian QQ, et al. Scopoletin Ameliorates Anxiety-Like Behaviors in Complete Freund's Adjuvant-Induced Mouse Model. Mol Brain (2020) 13:1-13. doi: 10.1186/s13041-020-0560-2

253. Zhang W, Zhao W, Ge C, Li X, Sun Z. Scopoletin Attenuates Intracerebral Hemorrhage-Induced Brain Injury and Improves Neurological Performance in Rats. Neuroimmunomodulation (2021) 28:74-81. doi: 10.1159/000505731

254. Lee JH, Ki TL, Jae HY, Nam IB, Dae KK. Acetylcholinesterase Inhibitors From the Twigs of Vaccinium Oldhami Miquel. Arch Pharm Res (2004) 27:53-6. doi: 10.1007/BF02980046

255. Orhan I, Tosun F, Şener B. Coumarin, Anthroquinone and Stilbene Derivatives With Anticholinesterase Activity. Z Fur Naturforsch - Sect C J Biosci (2008) 63:366-70. doi: 10.1515/znc-2008-5-610

256. Suchaichit N, Kanokmedhakul S, Kanokmedhakul K, Moosophon P, Boonyarat C, Plekratoke $\mathrm{K}$, et al. Phytochemical Investigation and Acetylcholinesterase Inhibitory Activity of Bark of Hymenodictyon Orixense. Nat Prod Res (2018) 32:2936-9. doi: 10.1080/14786419.2017. 1389930

257. Kuppusamy A, Arumugam M, George S. Combining in Silico and In Vitro Approaches to Evaluate the Acetylcholinesterase Inhibitory Profile of Some Commercially Available Flavonoids in the Management of Alzheimer's Disease. Int J Biol Macromol (2017) 95:199-203. doi: 10.1016/ j.ijbiomac.2016.11.062

258. Malik J, Karan M, Vasisht K. Attenuating Effect of Bioactive Coumarins From Convolvulus Pluricaulis on Scopolamine-Induced Amnesia in Mice. Nat Prod Res (2016) 30:578-82. doi: 10.1080/14786419.2015.1025398

259. Hornick A, Lieb A, Vo NP, Rollinger JM, Stuppner H, Prast H. The Coumarin Scopoletin Potentiates Acetylcholine Release From Synaptosomes, Amplifies Hippocampal Long-Term Potentiation and Ameliorates Anticholinergic- and Age-Impaired Memory. Neuroscience (2011) 197:280-92. doi: 10.1016/j.neuroscience.2011.09.006

260. Monsef-Esfahani HR, Amini M, Goodarzi N, Saiedmohammadi F, Hajiaghaee R, Faramarzi MA, et al. Coumarin Compounds of Biebersteinia Multifida Roots Show Potential Anxiolytic Effects in Mice. DARU J Pharm Sci (2013) 21:51. doi: 10.1186/2008-2231-21-51

261. Pandy V, Vijeepallam K. Antipsychotic-Like Activity of Scopoletin and Rutin Against the Positive Symptoms of Schizophrenia in Mouse Models. Exp Anim (2017) 66:417-23. doi: 10.1538/expanim.17-0050

262. Mishra N, Oraon A, Dev A, Jayaprakash V, Basu A, Pattnaik AK, et al. Anticonvulsant Activity of Benkara Malabarica (Linn.) Root Extract: In vitro and in vivo investigation. J Ethnopharmacol (2010) 128:533-6. doi: 10.1016/ j.jep.2010.01.042

263. Zhou R, Kan S, Cai S, Sun R, Yuan H, Yu B. Scopoletin Activates Adenosine Monophosphate-Activated Protein Kinase/Mammalian Target of Rapamycin Signaling Pathway and Improves Functional Recovery After Spinal Cord Injury in Rats. Pharmacology (2020) 105:349-59. doi: 10.1159/ 000503866

264. Das R, Sengupta T, Roy S, Chattarji S, Ray J. Convolvulus Pluricaulis Extract Can Modulate Synaptic Plasticity in Rat Brain Hippocampus. Neuroreport (2020) 31(8):597-604. doi: 10.1097/WNR.0000000000001446

265. Kayser O, Kolodziej H. Antibacterial Activity of Extracts and Constituents of Pelargonium Sidoides and Pelargonium Reniforme. Planta Med (1997) 63:508-10. doi: 10.1055/s-2006-957752

266. Lemos ASO, Florêncio JR, Pinto NCC, Campos LM, Silva TP, Grazul RM, et al. Antifungal Activity of the Natural Coumarin Scopoletin Against Planktonic Cells and Biofilms From a Multidrug-Resistant Candida Tropicalis Strain. Front Microbiol (2020) 11:1525. doi: 10.3389/ fmicb. 2020.01525

267. More G, Lall N, Hussein A, Tshikalange TE. Antimicrobial Constituents of Artemisia Afra Jacq. Ex Willd. Against Periodontal Pathogens. EvidenceBased Complement Altern Med (2012) 2012:252758. doi: 10.1155/2012/ 252758

268. Navarro-García VM, Rojas G, Avilés M, Fuentes M, Zepeda G. In Vitro Antifungal Activity of Coumarin Extracted From Loeselia Mexicana Brand. Mycoses (2011) 54:e569-71. doi: 10.1111/j.1439-0507.2010.01993.x 
269. Meerungrueang W, Panichayupakaranant P. Antimicrobial Activities of Some Thai Traditional Medical Longevity Formulations From Plants and Antibacterial Compounds From Ficus Foveolata. Pharm Biol (2014) 52:1104-9. doi: 10.3109/13880209.2013.877493

270. Ramírez-Reyes TI, Aguilar-Colorado ÁS, Murrieta-León DL, LiconaVelázquez LS, Bonilla-Landa I, Durán-Espinosa C, et al. Identification of Antibacterial Phenolics in Selected Plant Species From Mexican Cloud Forest by Mass Spectrometry Dereplication. Chem Biodivers (2019) 16: e1800603. doi: $10.1002 / \mathrm{cbdv} .201800603$

271. Sokoudjou JB, Atolani O, Njateng GSS, Khan A, Tagousop CN, Bitombo AN, et al. Isolation, Characterization and In Vitro Anti-Salmonellal Activity of Compounds From Stem Bark Extract of Canarium Schweinfurthii. BMC Complement Med Ther (2020) 20(1):316. doi: 10.1186/s12906-020-03100-5

272. Duncan SH, Flint HJ, Stewart CS. Inhibitory Activity of Gut Bacteria Against Escherichia Coli O157 Mediated by Dietary Plant Metabolites. FEMS Microbiol Lett (1998) 164:283-8. doi: 10.1111/j.1574-6968.1998.tb13099.x

273. Kuigoua GM, Kouam SF, Ngadjui BT, Schulz B, Green IR, Choudhary MI, et al. Minor Secondary Metabolic Products From the Stem Bark of Plumeria Rubra Linn. Displaying Antimicrobial Activities. Planta Med (2010) 76:6205. doi: 10.1055/s-0029-1240611

274. Chiang CC, Cheng MJ, Peng CF, Huang HY, Chen IS. A Novel Dimeric Coumarin Analog and Antimycobacterial Constituents From Fatoua Pilosa. Chem Biodivers (2010) 7:1728-36. doi: 10.1002/cbdv.200900326

275. Duggirala S, Nankar RP, Rajendran S, Doble M. Phytochemicals as Inhibitors of Bacterial Cell Division Protein FtsZ: Coumarins Are Promising Candidates. Appl Biochem Biotechnol (2014) 174:283-96. doi: 10.1007/ s12010-014-1056-2

276. Buathong R, Chamchumroon V, Schinnerl J, Bacher M, Santimaleeworagun W, Kraichak E, et al. Chemovariation and Antibacterial Activity of Extracts and Isolated Compounds From Species of Ixora and Greenea (Ixoroideae, Rubiaceae). PeerJ (2019) 2019:e6893. doi: 10.7717/peerj.6893

277. De La Cruz-Sánchez NG, Gómez-Rivera A, Alvarez-Fitz P, Ventura-Zapata E, Pérez-García MD, Avilés-Flores M, et al. Antibacterial Activity of Morinda Citrifolia Linneo Seeds Against Methicillin-Resistant Staphylococcus Spp. Microb Pathog (2019) 128:347-53. doi: 10.1016/j.micpath.2019.01.030

278. Das S, Czuni L, Báló V, Papp G, Gazdag Z, Papp N, et al. Cytotoxic Action of Artemisinin and Scopoletin on Planktonic Forms and on Biofilms of Candida Species. Molecules (2020) 25(3):476. doi: 10.3390/molecules25030476

279. Choi BR, Kumar SK, Zhao C, Zhang LT, Kim CY, Lee SW, et al. Additive Effects of Artemisia Capillaris Extract and Scopoletin on the Relaxation of Penile Corpus Cavernosum Smooth Muscle. Int J Impot Res (2015) 27:22532. doi: 10.1038/ijir.2015.23

280. Lee JH, Lee DU, Kim YS, Kim HP. 5-Lipoxygenase Inhibition of the Fructus of Foeniculum Vulgare and Its Constituents. Biomol Ther (2012) 20:113-7. doi: 10.4062/biomolther.2012.20.1.113

281. Yoshiyuki K, Hiromichi O, Shigeru A, Kimiye B, Mitsugi K. Inhibition of the Formation of 5-Hydroxy-6,8,11,14-Eicosatetraenoic Acid From Arachidonic Acid in Polymorphonuclear Leukocytes by Various Coumarins. Biochim Biophys Acta (BBA)/Lipids Lipid Metab (1985) 834:224-9. doi: 10.1016/00052760(85)90159-6

282. Oshima N, Narukawa Y, Takeda T, Kiuchi F. Collagenase Inhibitors From Viola Yedoensis. J Nat Med (2013) 67:240-5. doi: 10.1007/s11418-012-0665-8

283. Patel MR, Bhalodia YS, Pathak NL, Patel MS, Suthar K, Patel N, et al. Study on the Mechanism of the Bronchodilatory Effects of Cynodon Dactylon (Linn.) and Identification of the Active Ingredient. J Ethnopharmacol (2013) 150:946-52. doi: 10.1016/j.jep.2013.09.053

284. Lee HE, Yang G, Choi JS, Lee JY. Suppression of Primary Splenocyte Proliferation by Artemisia Capillaris and Its Components. Toxicol Res (2017) 33:283-90. doi: 10.5487/TR.2017.33.4.283

285. Thabet AA, Youssef FS, Korinek M, Chang FR, Wu YC, Chen BH, et al. Study of the Anti-Allergic and Anti-Inflammatory Activity of Brachychiton Rupestris and Brachychiton Discolor Leaves (Malvaceae) Using In Vitro Models. BMC Complement Altern Med (2018) 18(1):299. doi: 10.1186/ s12906-018-2359-6

286. Ren W, Wang Y, He Q, Zhou Y, Li C, Wang W, et al. Chemical Composition of Erycibe Schmidtii and Antiproliferative Activity of Scopoletin on Immature Dendritic Cells. Nat Prod Res (2020) 34:2581-8. doi: 10.1080/ 14786419.2018.1547292
287. Alkorashy AI, Doghish AS, Abulsoud AI, Ewees MG, Abdelghany TM, Elshafey MM, et al. Effect of Scopoletin on Phagocytic Activity of U937Derived Human Macrophages: Insights From Transcriptomic Analysis. Genomics (2020) 112:3518-24. doi: 10.1016/j.ygeno.2020.03.022

288. Cheng AS, Cheng YH, Chang TL. Scopoletin Attenuates Allergy by Inhibiting Th2 Cytokines Production in EL-4 T Cells. Food Funct (2012) 3:886-90. doi: 10.1039/c2fo30054k

289. Nam H, Kim MM. Scopoletin Has a Potential Activity for Anti-Aging via Autophagy in Human Lung Fibroblasts. Phytomedicine (2015) 22:362-8. doi: 10.1016/j.phymed.2015.01.004

290. Kim HL, Min Woo S, Rin Choi W, Kim HS, Chunsik Y, Kim KH, et al. Scopoletin Downregulates MMP-1 Expression in Human Fibroblasts via Inhibition of P38 Phosphorylation. Int J Mol Med (2018) 42:1917-24. doi: $10.3892 / \mathrm{ijmm} .2018 .3757$

291. Wan Osman WNF, Che Ahmad Tantowi NA, Lau SF, Mohamed S. Epicatechin and Scopoletin Rich Morinda Citrifolia (Noni) Leaf Extract Supplementation, Mitigated Osteoarthritis via Anti-Inflammatory, AntiOxidative, and Anti-Protease Pathways. J Food Biochem (2019) 43:e12755. doi: $10.1111 /$ jfbc. 12755

292. Lee SH, Ding Y, Yan XT, Kim YH, Jang HD. Scopoletin and Scopolin Isolated From Artemisia Iwayomogi Suppress Differentiation of Osteoclastic Macrophage RAW 264.7 Cells by Scavenging Reactive Oxygen Species. J Nat Prod (2013) 76:615-20. doi: 10.1021/np300824h

293. Wu YB, Zheng CJ, Qin LP, Sun LN, Han T, Jiao L, et al. Antiosteoporotic Activity of Anthraquinones From Morinda Officinalis on Osteoblasts and Osteoclasts. Molecules (2009) 14:573-83. doi: 10.3390/molecules14010573

294. Nima S, Kasiwong S, Ridtitid W, Thaenmanee N, Mahattanadul S. Gastrokinetic Activity of Morinda Citrifolia Aqueous Fruit Extract and Its Possible Mechanism of Action in Human and Rat Models. J Ethnopharmacol (2012) 142:354-61. doi: 10.1016/j.jep.2012.04.044

295. Awaad AS, Al-Rifai AA, El-Meligy RM, Alafeefy AM, Zain ME. New Activities for Isolated Compounds From Convolvulus Austro-Aegyptiacus as Anti-Ulcerogenic, Anti-Helicobacter Pylori and Their Mimic Synthesis Using Bio-Guided Fractionation. Phyther Res (2015) 29:1311-6. doi: $10.1002 /$ ptr.5379

296. Ahn MJ, Hur SJ, Kim EH, Lee SH, Shin JS, Kim MK, et al. Scopoletin From Cirsium Setidens Increases Melanin Synthesis via CREB Phosphorylation in B16F10 Cells. Korean J Physiol Pharmacol (2014) 18:307-11. doi: 10.4196/ kjpp.2014.18.4.307

297. Kim DS, Cha SB, Park MC, Park SA, Kim HS, Woo WH, et al. Scopoletin Stimulates Melanogenesis via cAMP/Pka Pathway and Partially P38 Activation. Biol Pharm Bull (2017) 40:2068-74. doi: 10.1248/bpb.b16-00690

298. Heriniaina RM, Dong J, Kalavagunta PK, Wu HL, Yan DS, Shang J. Effects of Six Compounds With Different Chemical Structures on Melanogenesis. Chin J Nat Med (2018) 16:766-73. doi: 10.1016/S1875-5364(18)30116-X

299. Srilatha K, Reddy KP. Sciatic Nerve Structural and Functional Recovery With Extract of Phyllanthus Amarus and Esculetin in STZ-Induced Hyperglycemic Rats. Ann Neurosci (2019) 26:17-29. doi: 10.1177/0972753120911840

300. Shin E, Choi KM, Yoo HS, Lee CK, Hwang BY, Lee MK. Inhibitory Effects of Coumarins From the Stem Barks of Fraxinus Rhynchophylla on Adipocyte Differentiation in 3T3-L1 Cells. Biol Pharm Bull (2010) 33:1610-4. doi: 10.1248/bpb.33.1610

301. Yang JY, Della-Fera MA, Baile CA. Esculetin Induces MitochondriaMediated Apoptosis in 3T3-L1 Adipocytes. Apoptosis (2006) 11:1371-8. doi: 10.1007/s10495-006-7691-5

302. Yang JY, Della-Fera MA, Hartzell DL, Nelson-Dooley C, Hausman DB, Baile CA. Esculetin Induces Apoptosis and Inhibits Adipogenesis in 3T3-L1 Cells. Obesity (2006) 14:1691-9. doi: 10.1038/oby.2006.194

303. Kadakol A, Goru SK, Malek V, Gaikwad AB. Esculetin Ameliorates Vascular Perturbation by Intervening in the Occupancy of H2BK120Ub at At1, At2, Tgf $\beta 1$ and Mcp1 Promoter Gene in Thoracic Aorta of IR and T2D Rats. BioMed Pharmacother (2017) 95:1461-8. doi: 10.1016/j.biopha.2017.09.067

304. Sung YY, Kim DS, Kim HK. Viola Mandshurica Ethanolic Extract Prevents High-Fat-Diet-Induced Obesity in Mice by Activating AMP-Activated Protein Kinase. Environ Toxicol Pharmacol (2014) 38:41-50. doi: 10.1016/ j.etap. 2014.04 .028

305. Prabakaran D, Ashokkumar N. Protective Effect of Esculetin on Hyperglycemia-Mediated Oxidative Damage in the Hepatic and Renal 
Tissues of Experimental Diabetic Rats. Biochimie (2013) 95:366-73. doi: 10.1016/j.biochi.2012.10.008

306. Choi RY, Ham JR, Lee MK. Esculetin Prevents Non-Alcoholic Fatty Liver in Diabetic Mice Fed High-Fat Diet. Chem Biol Interact (2016) 260:13-21. doi: 10.1016/j.cbi.2016.10.013

307. Kim Y, Park Y, Namkoong S, Lee J. Esculetin Inhibits the Inflammatory Response by Inducing Heme Oxygenase-1 in Cocultured Macrophages and Adipocytes. Food Funct (2014) 5:2371-7. doi: 10.1039/c4fo00351a

308. Kim Y, Lee J. Esculetin Inhibits Adipogenesis and Increases Antioxidant Activity During Adipocyte Differentiation in 3T3-L1 Cells. Prev Nutr Food Sci (2017) 22:118-23. doi: 10.3746/pnf.2017.22.2.118

309. Pandey A, Raj P, Goru SK, Kadakol A, Malek V, Sharma N, et al. Esculetin Ameliorates Hepatic Fibrosis in High Fat Diet Induced Non-Alcoholic Fatty Liver Disease by Regulation of FoxO1 Mediated Pathway. Pharmacol Rep (2017) 69:666-72. doi: 10.1016/j.pharep.2017.02.005

310. Kadakol A, Malek V, Goru SK, Pandey A, Bagal S, Gaikwad AB. Esculetin Attenuates Alterations in Ang II and Acetylcholine Mediated Vascular Reactivity Associated With Hyperinsulinemia and Hyperglycemia. Biochem Biophys Res Commun (2015) 461:342-7. doi: 10.1016/ j.bbrc.2015.04.036

311. Karmase A, Jagtap S, Bhutani KK. Anti Adipogenic Activity of Aegle Marmelos Correa. Phytomedicine (2013) 20:1267-71. doi: 10.1016/ j.phymed.2013.07.011

312. Yang ZG, Jia LN, Shen Y, Ohmura A, Kitanaka S. Inhibitory Effects of Constituents From Euphorbia Lunulata on Differentiation of 3T3-L1 Cells and Nitric Oxide Production in RAW264.7 Cells. Molecules (2011) 16:830518. doi: $10.3390 /$ molecules 16108305

313. Pan SL, Huang YW, Guh JH, Chang YL, Peng CY, Teng CM. Esculetin Inhibits Ras-Mediated Cell Proliferation and Attenuates Vascular Restenosis Following Angioplasty in Rats. Biochem Pharmacol (2003) 65:1897-905. doi: 10.1016/S0006-2952(03)00161-8

314. Junior AG, Tolouei SEL, dos Reis Lívero FA, Gasparotto F, Boeing T, de Souza P. Natural Agents Modulating ACE-2: A Review of Compounds With Potential Against SARS-CoV-2 Infections. Curr Pharm Des (2021) 27:158896. doi: $10.2174 / 1381612827666210114150607$

315. Hsia CW, Lin KC, Lee TY, Hsia CH, Chou DS, Jayakumar T, et al. Esculetin, A Coumarin Derivative, Prevents Thrombosis: Inhibitory Signaling on Plcy2-PKC-AKT Activation in Human Platelets. Int J Mol Sci (2019) 20:2731. doi: 10.3390/ijms20112731

316. Lee SJ, Lee US, Kim WJ, Moon SK. Inhibitory Effect of Esculetin on Migration, Invasion and Matrix Metalloproteinase-9 Expression in TNF$\alpha$-Induced Vascular Smooth Muscle Cells. Mol Med Rep (2011) 4:337-41. doi: $10.3892 / \mathrm{mmr} .2011 .420$

317. He Y, Li C, Ma Q, Chen S. Esculetin Inhibits Oxidative Stress and Apoptosis in H9c2 Cardiomyocytes Following Hypoxia/Reoxygenation Injury. Biochem Biophys Res Commun (2018) 501:139-44. doi: 10.1016/j.bbrc.2018.04.195

318. Subramaniam SR, Ellis EM. Esculetin-Induced Protection of Human Hepatoma HepG2 Cells Against Hydrogen Peroxide Is Associated With the Nrf2-Dependent Induction of the NAD(P)H: Quinone Oxidoreductase 1 Gene. Toxicol Appl Pharmacol (2011) 250:130-6. doi: 10.1016/j. taap.2010.09.025

319. Abdallah H, Farag M, Osman S, Kim DH, Kang K, Pan CH, et al. Isolation of Major Phenolics From Launaea Spinosa and Their Protective Effect on HepG2 Cells Damaged With T-BHP. Pharm Biol (2016) 54:536-41. doi: 10.3109/13880209.2015.1052885

320. Tien YC, Liao JC, Chiu CS, Huang TH, Huang CY, Chang WT, et al. Esculetin Ameliorates Carbon Tetrachloride-Mediated Hepatic Apoptosis in Rats. Int J Mol Sci (2011) 12:4053-67. doi: 10.3390/ijms12064053

321. Kim AD, Han X, Piao MJ, Hewage SRKM, Hyun CL, Cho SJ, et al. Esculetin Induces Death of Human Colon Cancer Cells via the Reactive Oxygen Species-Mediated Mitochondrial Apoptosis Pathway. Environ Toxicol Pharmacol (2015) 39:982-9. doi: 10.1016/j.etap.2015.03.003

322. Kim WK, Byun WS, Chung HJ, Oh J, Park HJ, Choi JS, et al. Esculetin Suppresses Tumor Growth and Metastasis by Targeting Axin2/E-Cadherin Axis in Colorectal Cancer. Biochem Pharmacol (2018) 152:71-83. doi: 10.1016/j.bcp.2018.03.009

323. Lee RH, Jeon YJ, Cho JH, Jang JY, Kong IK, Kim SH, et al. Esculetin Exerts Anti-Proliferative Effects Against Non-Small-Cell Lung Carcinoma by
Suppressing Specificity Protein 1 In Vitro. Gen Physiol Biophys (2017) 36:31-9. doi: 10.4149/gpb_2016024

324. Lee SY, Lim TG, Chen H, Jung SK, Lee HJ, Lee MH, et al. Esculetin Suppresses Proliferation of Human Colon Cancer Cells by Directly Targeting $\beta$-Catenin. Cancer Prev Res (2013) 6:1356-64. doi: 10.1158/ 1940-6207.CAPR-13-0241

325. Li H, Wang Q, Wang Y, Xu Z, Han Z. Esculetin Inhibits the Proliferation of Human Lung Cancer Cells by Targeting Epithelial-to-Mesenchymal Transition of the Cells. Cell Mol Biol (2019) 65:95-8. doi: 10.14715/cmb/ 2019.65.7.16

326. Pan H, Wang BH, Lv W, Jiang Y, He L. Esculetin Induces Apoptosis in Human Gastric Cancer Cells Through a Cyclophilin D-Mediated Mitochondrial Permeability Transition Pore Associated With ROS. Chem Biol Interact (2015) 242:51-60. doi: 10.1016/j.cbi.2015.09.015

327. Park C, Jin CY, Kim GY, Choi IW, Kwon TK, Choi BT, et al. Induction of Apoptosis by Esculetin in Human Leukemia U937 Cells Through Activation of JNK and ERK. Toxicol Appl Pharmacol (2008) 227:219-28. doi: 10.1016/ j.taap.2007.10.003

328. Park C, Jin CY, Kwon HJ, Hwang HJ, Kim GY, Choi IW, et al. Induction of Apoptosis by Esculetin in Human Leukemia U937 Cells: Roles of Bcl-2 and Extracellular-Regulated Kinase Signaling. Toxicol Vitr (2010) 24:486-94. doi: 10.1016/j.tiv.2009.09.017

329. Rubio V, García-Pérez AI, Herráez A, Tejedor MC, Diez JC. Esculetin Modulates Cytotoxicity Induced by Oxidants in NB4 Human Leukemia Cells. Exp Toxicol Pathol (2017) 69:700-12. doi: 10.1016/j.etp.2017.08.001

330. Arora R, Sawney S, Saini V, Steffi C, Tiwari M, Saluja D. Esculetin Induces Antiproliferative and Apoptotic Response in Pancreatic Cancer Cells by Directly Binding to KEAP1. Mol Cancer (2016) 15:1-15. doi: 10.1186/ s12943-016-0550-2

331. Sawney S, Arora R, Aggarwal KK, Saluja D. Esculetin Downregulates the Expression of AML1-ETO and C-Kit in Kasumi-1 Cell Line by Decreasing Half-Life of mRNA. J Oncol (2015) 2015:781473. doi: 10.1155/2015/781473

332. Turkekul K, Colpan RD, Baykul T, Ozdemir MD, Erdogan S. Esculetin Inhibits the Survival of Human Prostate Cancer Cells by Inducing Apoptosis and Arresting the Cell Cycle. J Cancer Prev (2018) 23:10-7. doi: 10.15430/ jcp.2018.23.1.10

333. Wang G, Lu M, Yao Y, Wang J, Li J. Esculetin Exerts Antitumor Effect on Human Gastric Cancer Cells Through IGF-1/PI3K/Akt Signaling Pathway. Eur J Pharmacol (2017) 814:207-15. doi: 10.1016/j.ejphar.2017.08.025

334. Yang J, Xiao YL, He XR, Qiu GF, Hu XM. Aesculetin-Induced Apoptosis Through a ROS-Mediated Mitochondrial Dysfunction Pathway in Human Cervical Cancer Cells. J Asian Nat Prod Res (2010) 12:185-93. doi: 10.1080/ 10286020903427336

335. Zhang G, Xu Y, Zhou HF. Esculetin Inhibits Proliferation, Invasion, and Migration of Laryngeal Cancer In Vitro and In Vivo by Inhibiting Janus Kinas (JAK)-Signal Transducer and Activator of Transcription-3 (STAT3) Activation. Med Sci Monit (2019) 25:7853-63. doi: 10.12659/MSM.916246

336. Wu ST, Liu B, Ai ZZ, Hong ZC, You PT, Wu HZ, et al. Esculetin Inhibits Cancer Cell Glycolysis by Binding Tumor PGK2, GPD2, and GPI. Front Pharmacol (2020) 11:379. doi: 10.3389/fphar.2020.00379

337. Chang HT, Chou CT, Lin YS, Shieh P, Kuo DH, Jan CR, et al. Esculetin, a Natural Coumarin Compound, Evokes Ca2+ Movement and Activation of Ca2+-Associated Mitochondrial Apoptotic Pathways That Involved Cell Cycle Arrest in ZR-75-1 Human Breast Cancer Cells. Tumor Biol (2016) 37:4665-78. doi: 10.1007/s13277-015-4286-1

338. Chu CY, Tsai YY, Wang CJ, Lin WL, Tseng TH. Induction of Apoptosis by Esculetin in Human Leukemia Cells. Eur J Pharmacol (2001) 416:25-32. doi: 10.1016/S0014-2999(01)00859-7

339. Duan J, Shi J, Ma X, Xuan Y, Li P, Wang H, et al. Esculetin Inhibits Proliferation, Migration, and Invasion of Clear Cell Renal Cell Carcinoma Cells. BioMed Pharmacother (2020) 125:110031. doi: 10.1016/j.biopha.2020.110031

340. Gong J, Zhang WG, Feng XF, Shao MJ, Xing C. Aesculetin (6,7Dihydroxycoumarin) Exhibits Potent and Selective Antitumor Activity in Human Acute Myeloid Leukemia Cells (THP-1) via Induction of Mitochondrial Mediated Apoptosis and Cancer Cell Migration Inhibition. J BUON (2017) 22:1563-9.

341. Karatug Kacar A, Bahadori F, Kepekci Tekkeli SE, Topcu G, Bolkent S. Investigation of Cell Death Mechanism and Activity of Esculetin-Loaded 
PLGA Nanoparticles on Insulinoma Cells In Vitro. J Pharm Pharmacol (2020) 72:592-606. doi: 10.1111/jphp.13228

342. Kawaii S, Tomono Y, Ogawa K, Sugiura M, Yano M, Yoshizawa Y. The Antiproliferative Effect of Coumarins on Several Cancer Cell Lines. Anticancer Res (2001) 21:917-24.

343. Wang X, Yang C, Zhang Q, Wang C, Zhou X, Zhang X, et al. In Vitro Anticancer Effects of Esculetin Against Human Leukemia Cell Lines Involves Apoptotic Cell Death, Autophagy, G0/G1 Cell Cycle Arrest and Modulation of Raf/MEK/ERK Signalling Pathway. J BUON (2019) 24:1686-91.

344. Cho JH, Shin JC, Cho JJ, Choi YH, Shim JH, Chae J. Esculetin (6, 7Dihydroxycoumarin): A Potential Cancer Chemopreventive Agent Through Suppression of Sp1 in Oral Squamous Cancer Cells. Int J Oncol (2015) 46:265-71. doi: 10.3892/ijo.2014.2700

345. Li J, Li S, Wang X, Wang H. Esculetin Induces Apoptosis of SMMC-7721 Cells Through IGF-1/PI3K/Akt-Mediated Mitochondrial Pathways. Can J Physiol Pharmacol (2017) 95:787-94. doi: 10.1139/cjpp-2016-0548

346. Sharma SH, Thulasingam S, Chellappan DR, Chinnaswamy P, Nagarajan S. Morin and Esculetin Supplementation Modulates C-Myc Induced Energy Metabolism and Attenuates Neoplastic Changes in Rats Challenged With the Procarcinogen 1,2 - Dimethylhydrazine. Eur J Pharmacol (2017) 796:20-31. doi: 10.1016/j.ejphar.2016.12.019

347. Wang CJ, Hsieh YJ, Chu CY, Lin YL, Tseng TH. Inhibition of Cell Cycle Progression in Human Leukemia HL-60 Cells by Esculetin. Cancer Lett (2002) 183:163-8. doi: 10.1016/S0304-3835(02)00031-9

348. Park S-S, Park S-K, Jung-Hyurk L, Choi YH, Kim WJ, Moon SK. Esculetin Inhibits Cell Proliferation Through the Ras/ERK1/2 Pathway in Human Colon Cancer Cells. Oncol Rep (2010) 25:223-30. doi: 10.3892/or_00001064

349. Lacy A. Studies on Coumarins and Coumarin-Related Compounds to Determine Their Therapeutic Role in the Treatment of Cancer. Curr Pharm Des (2005) 10:3797-811. doi: 10.2174/1381612043382693

350. Fylaktakidou K, Hadjipavlou-Litina D, Litinas K, Nicolaides D. Natural and Synthetic Coumarin Derivatives With Anti-Inflammatory / Antioxidant Activities. Curr Pharm Des (2005) 10:3813-33. doi: 10.2174/ 1381612043382710

351. Hong SH, Jeong HK, Han MH, Park C, Choi YH. Esculetin Suppresses Lipopolysaccharide-Induced Inflammatory Mediators and Cytokines by Inhibiting Nuclear Factor- $\kappa b$ Translocation in RAW 264.7 Macrophages. Mol Med Rep (2014) 10:3241-6. doi: 10.3892/mmr.2014.2613

352. Kim AR, Jin Q, Jin HG, Ko HJ, Woo ER. Phenolic Compounds With IL-6 Inhibitory Activity From Aster Yomena. Arch Pharm Res (2014) 37:845-51. doi: 10.1007/s12272-013-0236-x

353. Kim SH, Kang KA, Zhang R, Piao MJ, Ko DO, Wang ZH, et al. Protective Effect of Esculetin Against Oxidative Stress-Induced Cell Damage via Scavenging Reactive Oxygen Species. Acta Pharmacol Sin (2008) 29:131926. doi: $10.1111 /$ j.1745-7254.2008.00878.x

354. Kwon OS, Choi JS, Islam MN, Kim YS, Kim HP. Inhibition of 5Lipoxygenase and Skin Inflammation by the Aerial Parts of Artemisia Capillaris and Its Constituents. Arch Pharm Res (2011) 34:1561-9. doi: 10.1007/s12272-011-0919-0

355. Nazemiyeh H, Kazemi EM, Zare K, Jodari M, Nahar L, Sarker SD. Free Radical Scavengers From the Aerial Parts of Euphorbia Petiolata. J Nat Med (2010) 64:187-90. doi: 10.1007/s11418-009-0382-0

356. Chen T, Guo Q, Wang H, Zhang H, Wang C, Zhang P, et al. Effects of Esculetin on Lipopolysaccharide (LPS)-Induced Acute Lung Injury via Regulation of RhoA/Rho Kinase/NF-kb Pathways In Vivo and In Vitro. Free Radic Res (2015) 49:1459-68. doi: 10.3109/10715762.2015.1087643

357. Lee HC, Liu FC, Tsai CN, Chou AH, Liao CC, Yu HP. Esculetin Ameliorates Lipopolysaccharide-Induced Acute Lung Injury in Mice Via Modulation of the AKT/ERK/NF-Kb and Roryt/IL-17 Pathways. Inflammation (2020) 43:962-74. doi: 10.1007/s10753-020-01182-4

358. Rzodkiewicz P, Gąsińska E, Gajewski M, Bujalska-Zadrozny M, Szukiewicz D, Maśliński S. Esculetin Reduces Leukotriene B4 Level in Plasma of Rats With Adjuvant-Induced Arthritis. Reumatologia (2016) 54:161-4. doi: 10.5114/reum.2016.62469

359. Rzodkiewicz P, Gasinska E, Maslinski S, Bujalska-Zadrozny M. Antinociceptive Properties of Esculetin in Non-Inflammatory and Inflammatory Models of Pain in Rats. Clin Exp Pharmacol Physiol (2015) 42:213-9. doi: 10.1111/1440-1681.12346
360. Witaicenis A, Seito LN, Di Stasi LC. Intestinal Anti-Inflammatory Activity of Esculetin and 4-Methylesculetin in the Trinitrobenzenesulphonic Acid Model of Rat Colitis. Chem Biol Interact (2010) 186:211-8. doi: 10.1016/ j.cbi.2010.03.045

361. Cheng Y-J, Tian X-L, Zeng Y-Z, Lan N, Guo L-F, Liu K-F, et al. Esculetin Protects Against Early Sepsis via Attenuating Inflammation by Inhibiting NF- $\mathrm{kb}$ and STAT1/STAT3 Signaling. Chin J Nat Med (2021) 19:432-41. doi: 10.1016/S1875-5364(21)60042-0

362. Han MH, Park C, Lee DS, Hong SH, Choi IW, Kim GY, et al. Cytoprotective Effects of Esculetin Against Oxidative Stress Are Associated With the Upregulation of Nrf2-Mediated NQO1 Expression via the Activation of the ERK Pathway. Int J Mol Med (2017) 39:380-6. doi: 10.3892/ ijmm.2016.2834

363. Kaneko T, Tahara S, Takabayashi F. Inhibitory Effect of Natural Coumarin Compounds, Esculetin and Esculin, on Oxidative DNA Damage and Formation of Aberrant Crypt Foci and Tumors Induced by 1,2Dimethylhydrazine in Rat Colons. Biol Pharm Bull (2007) 30:2052-7. doi: $10.1248 / \mathrm{bpb} .30 .2052$

364. Kaneko T, Tahara S, Takabayashi F. Suppression of Lipid HydroperoxideInduced Oxidative Damage to Cellular DNA by Esculetin. Biol Pharm Bull (2003) 26:840-4. doi: 10.1248/bpb.26.840

365. Lin WL, Wang CJ, Tsai YY, Liu CL, Hwang JM, Tseng TH. Inhibitory Effect of Esculetin on Oxidative Damage Induced by T-Butyl Hydroperoxide in Rat Liver. Arch Toxicol (2000) 74:467-72. doi: 10.1007/s002040000148

366. Yum S, Jeong S, Lee S, Kim W, Nam J, Jung Y. HIF-Prolyl Hydroxylase Is a Potential Molecular Target for Esculetin-Mediated Anti-Colitic Effects. Fitoterapia (2015) 103:55-62. doi: 10.1016/j.fitote.2015.03.013

367. Lee C-R, Shin E-J, Kim H-C, Choi Y-S, Shin T, Wie M-B. Esculetin Inhibits N -Methyl- D -Aspartate Neurotoxicity via Glutathione Preservation in Primary Cortical Cultures. Lab Anim Res (2011) 27:259. doi: 10.5625/ lar.2011.27.3.259

368. Martín-Aragón S, Villar Á, Benedí J. Age-Dependent Effects of Esculetin on Mood-Related Behavior and Cognition From Stressed Mice Are Associated With Restoring Brain Antioxidant Status. Prog Neuropsychopharmacol Biol Psychiatry (2016) 65:1-16. doi: 10.1016/j.pnpbp.2015.08.007

369. Subramaniam SR, Ellis EM. Neuroprotective Effects of Umbelliferone and Esculetin in a Mouse Model of Parkinson's Disease. J Neurosci Res (2013) 91:453-61. doi: 10.1002/jnr.23164

370. Sulakhiya K, Keshavlal GP, Bezbaruah BB, Dwivedi S, Gurjar SS, Munde N, et al. Lipopolysaccharide Induced Anxiety- and Depressive-Like Behaviour in Mice Are Prevented by Chronic Pre-Treatment of Esculetin. Neurosci Lett (2016) 611:106-11. doi: 10.1016/j.neulet.2015.11.031

371. Zhu L, Nang C, Luo F, Pan H, Zhang K, Liu J, et al. Esculetin Attenuates Lipopolysaccharide (LPS)-Induced Neuroinflammatory Processes and Depressive-Like Behavior in Mice. Physiol Behav (2016) 163:184-92. doi: 10.1016/j.physbeh.2016.04.051

372. Wang C, Pei A, Chen J, Yu H, Sun ML, Liu CF, et al. A Natural Coumarin Derivative Esculetin Offers Neuroprotection on Cerebral Ischemia/ Reperfusion Injury in Mice. J Neurochem (2012) 121:1007-13. doi: 10.1111/j.1471-4159.2012.07744.x

373. Kart D, Reçber T, Nemutlu E, Sagiroglu M. Sub-Inhibitory Concentrations of Ciprofloxacin Alone and Combinations With Plant-Derived Compounds Against P. Aeruginosa Biofilms and Their Effects on the Metabolomic Profile of P. Aeruginosa Biofilms. Antibiotics (2021) 10:414. doi: 10.3390/ antibiotics10040414

374. Lee JH, Kim YG, Cho HS, Ryu SY, Cho MH, Lee J. Coumarins Reduce Biofilm Formation and the Virulence of Escherichia Coli O157:H7. Phytomedicine (2014) 21:1037-42. doi: 10.1016/j.phymed.2014.04.008

375. Tian LW, Pei Y, Zhang YJ, Wang YF, Yang CR. 7-O-Methylkaempferol and -Quercetin Glycosides From the Whole Plant of Nervilia Fordii. J Nat Prod (2009) 72:1057-60. doi: 10.1021/np800760p

376. Li L, Greene I, Readhead B, Menon MC, Kidd BA, Uzilov AV, et al. Novel Therapeutics Identification for Fibrosis in Renal Allograft Using Integrative Informatics Approach. Sci Rep (2017) 7:1-14. doi: 10.1038/srep39487

377. Li JM, Zhang X, Wang X, Xie YC, Kong LD. Protective Effects of Cortex Fraxini Coumarines Against Oxonate-Induced Hyperuricemia and Renal Dysfunction in Mice. Eur J Pharmacol (2011) 666:196-204. doi: 10.1016/ j.ejphar.2011.05.021 
378. Surse VM, Gupta J, Tikoo K. Esculetin Induced Changes in Mmp13 and Bmp6 Gene Expression and Histone H3 Modifications Attenuate Development of Glomerulosclerosis in Diabetic Rats. J Mol Endocrinol (2011) 46:245-54. doi: 10.1530/JME-10-0154

379. Türk E, Ozan Tekeli I, Özkan H, Uyar A, Cellat M, Kuzu M, et al. The Protective Effect of Esculetin Against Aluminium Chloride-Induced Reproductive Toxicity in Rats. Andrologia (2021) 53:e13930. doi: 10.1111/ and. 13930

380. Hongyan L. Esculetin Attenuates Th2 and Th17 Responses in an Ovalbumin-Induced Asthmatic Mouse Model. Inflammation (2016) 39:735-43. doi: 10.1007/s10753-015-0300-4

381. Leung KN, Leung PY, Kong LP, Leung P. Immunomodulatory Effects of Esculetin (6,7-Dihydroxycoumarin) on Murine Lymphocytes and Peritoneal Macrophages. Cell Mol Immunol (2005) 2:181-8.

382. Mabalirajan U, Dinda AK, Sharma SK, Ghosh B. Esculetin Restores Mitochondrial Dysfunction and Reduces Allergic Asthma Features in Experimental Murine Model. J Immunol (2009) 183:2059-67. doi: $10.4049 /$ jimmunol.0900342

383. Sun B, Wang B, Xu M. Esculetin Inhibits Histamine-Induced Expression of Inflammatory Cytokines and Mucin in Nasal Epithelial Cells. Clin Exp Pharmacol Physiol (2019) 46:821-7. doi: 10.1111/1440-1681.13128

384. Baek JM, Park SH, Cheon YH, Ahn SJ, Lee MS, Oh J, et al. Esculetin Attenuates Receptor Activator of Nuclear Factor Kappa-B Ligand-Mediated Osteoclast Differentiation Through C-Fos/nuclear Factor of Activated TCells C1 Signaling Pathway. Biochem Biophys Res Commun (2015) 461:33441. doi: 10.1016/j.bbrc.2015.04.034

385. Na W, Lee EJ, Kang MK, Kim YH, Kim DY, Oh H, et al. Aesculetin Inhibits Osteoclastic Bone Resorption Through Blocking Ruffled Border Formation and Lysosomal Trafficking. Int J Mol Sci (2020) 21:1-17. doi: 10.3390/ ijms 21228581

386. Liu M, Li Y, Pan J, Liu H, Wang S, Ju D, et al. Effect of Esculetin on Bone Metabolism in Ovariectomized Rats. J Tradit Chin Med = Chung i Tsa Chih Ying Wen Pan (2018) 38:896-903.

387. Ozal SA, Turkekul K, Gurlu V, Guclu H, Erdogan S. Esculetin Protects Human Retinal Pigment Epithelial Cells From Lipopolysaccharide-Induced Inflammation and Cell Death. Curr Eye Res (2018) 43:1169-76. doi: 10.1080/ 02713683.2018.1481517

388. Jiang D, Hu J, Liu X. Topical Administration of Esculetin as a Potential Therapy for Experimental Dry Eye Syndrome. Eye (2017) 31:1724-32. doi: 10.1038/eye.2017.117

389. Elliott S, Rowan AD, Carrère S, Koshy P, Catterall JB, Cawston TE. Esculetin Inhibits Cartilage Resorption Induced by Interleukin $1 \alpha$ in Combination With Oncostatin M. Ann Rheum Dis (2001) 60:158-65. doi: 10.1136/ $\operatorname{ard} .60 .2 .158$

390. Hosseini A, Razavi BM, Banach M, Hosseinzadeh H. Quercetin and Metabolic Syndrome: A Review. Phyther Res (2021) ptr.7144. doi: 10.1002/ ptr.7144

391. Shabbir U, Rubab M, Daliri EBM, Chelliah R, Javed A, Oh DH. Curcumin, Quercetin, Catechins and Metabolic Diseases: The Role of Gut Microbiota. Nutrients (2021) 13:1-24. doi: 10.3390/nu13010206

392. Sato S, Mukai Y. Modulation of Chronic Inflammation by Quercetin: The Beneficial Effects on Obesity. J Inflamm Res (2020) 13:421-31. doi: 10.2147/ JIR.S228361

393. Ebrahimpour S, Zakeri M, Esmaeili A. Crosstalk Between Obesity, Diabetes, and Alzheimer's Disease: Introducing Quercetin as an Effective Triple Herbal Medicine. Ageing Res Rev (2020) 62:101095. doi: 10.1016/ j.arr.2020.101095

394. Munhoz ACM, Frode TS. Isolated Compounds From Natural Products With Potential Antidiabetic Activity - A Systematic Review. Curr Diabetes Rev (2017) 14(1):36-106. doi: 10.2174/1573399813666170505120621

395. Gong G, Guan YY, Zhang ZL, Rahman K, Wang SJ, Zhou S, et al. Isorhamnetin: A Review of Pharmacological Effects. BioMed Pharmacother (2020) 128:110301. doi: 10.1016/j.biopha.2020.110301

396. Ahn J, Lee H, Kim S, Park J, Ha T. The Anti-Obesity Effect of Quercetin Is Mediated by the AMPK and MAPK Signaling Pathways. Biochem Biophys Res Commun (2008) 373:545-9. doi: 10.1016/j.bbrc.2008.06.077

397. Jiang H, Horiuchi Y, Hironao KY, Kitakaze T, Yamashita Y, Ashida H. Prevention Effect of Quercetin and Its Glycosides on Obesity and
Hyperglycemia Through Activating Ampk $\alpha$ in High-Fat Diet-Fed ICR Mice. J Clin Biochem Nutr (2020) 67:74-83. doi: 10.3164/jcbn.20-47

398. Dagher O, Mury P, Thorin-Trescases N, Noly PE, Thorin E, Carrier M. Therapeutic Potential of Quercetin to Alleviate Endothelial Dysfunction in Age-Related Cardiovascular Diseases. Front Cardiovasc Med (2021) 8:658400. doi: $10.3389 / \mathrm{fcvm} .2021 .658400$

399. Mirsafaei L, Reiner Ž, Shafabakhsh R, Asemi Z. Molecular and Biological Functions of Quercetin as a Natural Solution for Cardiovascular Disease Prevention and Treatment. Plant Foods Hum Nutr (2020) 75:307-15. doi: $10.1007 /$ s11130-020-00832-0

400. Deng Q, Li XX, Fang Y, Chen X, Xue J. Therapeutic Potential of Quercetin as an Antiatherosclerotic Agent in Atherosclerotic Cardiovascular Disease: A Review. Evidence-Based Complement Altern Med (2020) 2020:5926381. doi: $10.1155 / 2020 / 5926381$

401. Dabeek WM, Marra MV. Dietary Quercetin and Kaempferol: Bioavailability and Potential Cardiovascular-Related Bioactivity in Humans. Nutrients (2019) 11:2288. doi: 10.3390/nu11102288

402. Ferenczyova K, Kalocayova B, Bartekova M. Potential Implications of Quercetin and Its Derivatives in Cardioprotection. Int J Mol Sci (2020) 21:1585. doi: 10.3390/ijms21051585

403. Farghali H, Kemelo MK, Canová NK. SIRT1 Modulators in Experimentally Induced Liver Injury. Oxid Med Cell Longev (2019) 2019:8765954. doi: $10.1155 / 2019 / 8765954$

404. Bae M, Park YK, Lee JY. Food Components With Antifibrotic Activity and Implications in Prevention of Liver Disease. J Nutr Biochem (2018) 55:1-11. doi: 10.1016/j.jnutbio.2017.11.003

405. Almatroodi SA, Alsahli MA, Almatroudi A, Verma AK, Aloliqi A, Allemailem KS, et al. Potential Therapeutic Targets of Quercetin, a Plant Flavonol, and Its Role in the Therapy of Various Types of Cancer Through the Modulation of Various Cell Signaling Pathways. Molecules (2021) 26:1315. doi: 10.3390/molecules26051315

406. Orfali G di C, Duarte AC, Bonadio V, Martinez NP, de Araújo MEMB, Priviero FBM, et al. Review of Anticancer Mechanisms of Isoquercitin. World J Clin Oncol (2016) 7:189-99. doi: 10.5306/wjco.v7.i2.189

407. Jantan I, Haque MA, Arshad L, Harikrishnan H, Septama AW, MohamedHussein ZA. Dietary Polyphenols Suppress Chronic Inflammation by Modulation of Multiple Inflammation-Associated Cell Signaling Pathways. J Nutr Biochem (2021) 93:108634. doi: 10.1016/j.jnutbio.2021.108634

408. Wang Y, Tao B, Wan Y, Sun Y, Wang L, Sun J, et al. Drug Delivery Based Pharmacological Enhancement and Current Insights of Quercetin With Therapeutic Potential Against Oral Diseases. BioMed Pharmacother (2020) 128:110372. doi: 10.1016/j.biopha.2020.110372

409. Huang YY, Wang ZH, Deng LH, Wang H, Zheng Q. Oral Administration of Quercetin or Its Derivatives Inhibit Bone Loss in Animal Model of Osteoporosis. Oxid Med Cell Longev (2020) 2020:6080597. doi: 10.1155/ 2020/6080597

410. Ghorbani A. Mechanisms of Antidiabetic Effects of Flavonoid Rutin. BioMed Pharmacother (2017) 96:305-12. doi: 10.1016/j.biopha.2017.10.001

411. Habtemariam S, Lentini G. The Therapeutic Potential of Rutin for Diabetes: An Update. Mini-Rev Med Chem (2015) 15:524-8. doi: 10.2174/ 138955751507150424103721

412. Hosseinzadeh H, Nassiri-Asl M. Review of the Protective Effects of Rutin on the Metabolic Function as an Important Dietary Flavonoid. J Endocrinol Invest (2014) 37:783-8. doi: 10.1007/s40618-014-0096-3

413. Lim SH, Yu JS, Lee HS, Choi CI, Kim KH. Antidiabetic Flavonoids From Fruits of Morus Alba Promoting Insulin-Stimulated Glucose Uptake via Akt and Amp-Activated Protein Kinase Activation in 3t3-L1 Adipocytes. Pharmaceutics (2021) 13:526. doi: 10.3390/pharmaceutics13040526

414. Yuan X, Wei G, You Y, Huang Y, Lee HJ, Dong M, et al. Rutin Ameliorates Obesity Through Brown Fat Activation. FASEB J (2017) 31:333-45. doi: 10.1096/fj.201600459RR

415. Liang W, Zhang D, Kang J, Meng X, Yang J, Yang L, et al. Protective Effects of Rutin on Liver Injury in Type 2 Diabetic $\mathrm{Db} / \mathrm{Db}$ Mice. BioMed Pharmacother (2018) 107:721-8. doi: 10.1016/j.biopha.2018.08.046

416. Mainzen Prince PS, Kamalakkannan N. Rutin Improves Glucose Homeostasis in Streptozotocin Diabetic Tissues by Altering Glycolytic and Gluconeogenic Enzymes. J Biochem Mol Toxicol (2006) 20:96-102. doi: $10.1002 / j b t .20117$ 
417. Manzoni AG, Passos DF, Leitemperger JW, Storck TR, Doleski PH, Jantsch $\mathrm{MH}$, et al. Hyperlipidemia-Induced Lipotoxicity and Immune Activation in Rats Are Prevented by Curcumin and Rutin. Int Immunopharmacol (2020) 81:106217. doi: 10.1016/j.intimp.2020.106217

418. Prasad R, Prasad SB. Histoprotective Effect of Rutin Against CisplatinInduced Toxicities in Tumor-Bearing Mice: Rutin Lessens Cisplatin-Induced Toxicities. Hum Exp Toxicol (2021) 40:245-58. doi: 10.1177/ 0960327120947793

419. Caglayan C, Kandemir FM, Darendelioğlu E, Yıldırım S, Kucukler S, Dortbudak MB. Rutin Ameliorates Mercuric Chloride-Induced Hepatotoxicity in Rats via Interfering With Oxidative Stress, Inflammation and Apoptosis. J Trace Elem Med Biol (2019) 56:60-8. doi: 10.1016/ j.jtemb.2019.07.011

420. Elsawy H, Badr GM, Sedky A, Abdallah BM, Alzahrani AM, Abdel-Moneim AM. Rutin Ameliorates Carbon Tetrachloride (CCl4)-Induced Hepatorenal Toxicity and Hypogonadism in Male Rats. PeerJ (2019) 7:e7011. doi: 10.7717/peerj.7011

421. Li S, Li J, Pan R, Cheng J, Cui Q, Chen J, et al. Sodium Rutin Extends Lifespan and Health Span in Mice Including Positive Impacts on Liver Health. $\mathrm{Br} \mathrm{J}$ Pharmacol (2021) 8. doi: 10.1111/bph.15410

422. Imani A, Maleki N, Bohlouli S, Kouhsoltani M, Sharifi S, Maleki Dizaj S. Molecular Mechanisms of Anticancer Effect of Rutin. Phyther Res (2021) 35:2500-13. doi: 10.1002/ptr.6977

423. Nouri Z, Fakhri S, Nouri K, Wallace CE, Farzaei MH, Bishayee A. Targeting Multiple Signaling Pathways in Cancer: The Rutin Therapeutic Approach. Cancers (Basel) (2020) 12:1-34. doi: 10.3390/cancers12082276

424. Rakshit S, Shukla P, Verma A, Kumar Nirala S, Bhadauria M. Protective Role of Rutin Against Combined Exposure to Lipopolysaccharide and DGalactosamine-Induced Dysfunctions in Liver, Kidney, and Brain: Hematological, Biochemical, and Histological Evidences. J Food Biochem (2021) 45:e13605. doi: 10.1111/jfbc.13605

425. La Casa C, Villegas I, Alarcón de la Lastra C, Motilva V, Martín Calero MJ. Evidence for Protective and Antioxidant Properties of Rutin, a Natural Flavone, Against Ethanol Induced Gastric Lesions. J Ethnopharmacol (2000) 71:45-53. doi: 10.1016/S0378-8741(99)00174-9

426. Hartogh DJD, Tsiani E. Antidiabetic Properties of Naringenin: A Citrus Fruit Polyphenol. Biomolecules (2019) 9:99. doi: 10.3390/biom9030099

427. Nyane NA, Tlaila TB, Malefane TG, Ndwandwe DE, Owira PMO. Metformin-Like Antidiabetic, Cardio-Protective and Non-Glycemic Effects of Naringenin: Molecular and Pharmacological Insights. Eur J Pharmacol (2017) 803:103-11. doi: 10.1016/j.ejphar.2017.03.042

428. Sharma M, Akhtar N, Sambhav K, Shete G, Bansal A, Sharma S. Emerging Potential of Citrus Flavanones as an Antioxidant in Diabetes and Its Complications. Curr Top Med Chem (2014) 15:187-95. doi: 10.2174/ 1568026615666141209163013

429. Liu S, Dong J, Bian Q. A Dual Regulatory Effect of Naringenin on Bone Homeostasis in Two Diabetic Mice Models. Tradit Med Mod Med (2020) 03:101-8. doi: 10.1142/s2575900020500093

430. Heidary Moghaddam R, Samimi Z, Moradi SZ, Little PJ, Xu S, Farzaei MH. Naringenin and Naringin in Cardiovascular Disease Prevention: A Preclinical Review. Eur J Pharmacol (2020) 887:173535. doi: 10.1016/ j.ejphar.2020.173535

431. Mulvihill EE, Burke AC, Huff MW. Citrus Flavonoids as Regulators of Lipoprotein Metabolism and Atherosclerosis. Annu Rev Nutr (2016) 36:27599. doi: 10.1146/annurev-nutr-071715-050718

432. Hernández-Aquino E, Muriel P. Beneficial Effects of Naringenin in Liver Diseases: Molecular Mechanisms. World J Gastroenterol (2018) 24:1679-707. doi: 10.3748/wjg.v24.i16.1679

433. Memariani Z, Abbas SQ, ul Hassan SS, Ahmadi A, Chabra A. Naringin and Naringeninin as Anticancer Agents and Adjuvants in Cancer Combination Therapy; Efficacy and Molecular Mechanisms of Action, a Comprehensive Narrative Review. Pharmacol Res (2020) 171:105264. doi: 10.1016/ j.phrs.2020.105264

434. Zaidun NH, Thent ZC, Latiff AA. Combating Oxidative Stress Disorders With Citrus Flavonoid: Naringenin. Life Sci (2018) 208:111-22. doi: 10.1016/ j.lfs.2018.07.017

435. Tutunchi H, Naeini F, Ostadrahimi A, Hosseinzadeh-Attar MJ. Naringenin, a Flavanone With Antiviral and Anti-Inflammatory Effects: A Promising
Treatment Strategy Against COVID-19. Phyther Res (2020) 34:3137-47. doi: $10.1002 /$ ptr.6781

436. Alberca RW, Teixeira FME, Beserra DR, de Oliveira EA, Andrade MM de S, Pietrobon AJ, et al. Perspective: The Potential Effects of Naringenin in COVID-19. Front Immunol (2020) 11:570919. doi: 10.3389/fimmu. 2020.570919

437. Chin LH, Hon CM, Chellappan DK, Chellian J, Madheswaran T, Zeeshan F, et al. Molecular Mechanisms of Action of Naringenin in Chronic Airway Diseases. Eur J Pharmacol (2020) 879:173139. doi: 10.1016/j.ejphar.2020.173139

438. Mase A, Makino B, Tsuchiya N, Yamamoto M, Kase Y, Takeda S, et al. Active Ingredients of Traditional Japanese (Kampo) Medicine, Inchinkoto, in Murine Concanavalin A-Induced Hepatitis. J Ethnopharmacol (2010) 127:742-9. doi: 10.1016/j.jep.2009.11.029

439. Chu CY, Tseng TH, Hwang JM, Chou FP, Wang CJ. Protective Effects of Capillarisin on Tert-Butylhydroperoxide-Induced Oxidative Damage in Rat Primary Hepatocytes. Arch Toxicol (1999) 73:263-8. doi: 10.1007/ s002040050615

440. Lee JH, Chiang SY, Nam D, Chung WS, Lee J, Na YS, et al. Capillarisin Inhibits Constitutive and Inducible STAT3 Activation Through Induction of SHP-1 and SHP-2 Tyrosine Phosphatases. Cancer Lett (2014) 345:140-8. doi: 10.1016/j.canlet.2013.12.008

441. Tsui KH, Chang YL, Feng TH, Hou CP, Lin YH, Yang PS, et al. Capillarisin Blocks Prostate-Specific Antigen Expression on Activation of Androgen Receptor in Prostate Carcinoma Cells. Prostate (2018) 78:242-9. doi: $10.1002 /$ pros.23463

442. Tsui KH, Chang YL, Yang PS, Hou CP, Lin YH, Lin BW, et al. The Inhibitory Effects of Capillarisin on Cell Proliferation and Invasion of Prostate Carcinoma Cells. Cell Prolif (2018) 51(2):e12429. doi: 10.1111/cpr.12429

443. Chen NJ, Hao FY, Liu H, Zhao H, Li JM. Capillarisin Exhibits Anticancer Effects by Inducing Apoptosis, Cell Cycle Arrest and Mitochondrial Membrane Potential Loss in Osteosarcoma Cancer Cells (HOS). Drug Res (Stuttg) (2014) 65:422-7. doi: 10.1055/s-0034-1387728

444. Han S, Lee JH, Kim C, Nam D, Chung WS, Lee SG, et al. Capillarisin Inhibits iNOS, COX-2 Expression, and Proinflammatory Cytokines in LPS-Induced RAW 264.7 Macrophages via the Suppression of ERK, JNK, and NF-kb Activation. Immunopharmacol Immunotoxicol (2013) 35:34-42. doi: $10.3109 / 08923973.2012 .736522$

445. Khan S, Shehzad O, Chun J, Choi RJ, Park S, Islam MN, et al. AntiHyperalgesic and Anti-Allodynic Activities of Capillarisin via Suppression of Inflammatory Signaling in Animal Model. J Ethnopharmacol (2014) 152:478-86. doi: 10.1016/j.jep.2014.01.028

446. Khan S, Choi RJ, Shehzad O, Kim HP, Islam MN, Choi JS, et al. Molecular Mechanism of Capillarisin-Mediated Inhibition of MyD88/TIRAP Inflammatory Signaling in In Vitro and In Vivo Experimental Models. J Ethnopharmacol (2013) 145:626-37. doi: 10.1016/j.jep.2012.12.001

447. Kim J, Lim J, Kang BY, Jung K, Choi HJ. Capillarisin Augments AntiOxidative and Anti-Inflammatory Responses by Activating Nrf2/HO-1 Signaling. Neurochem Int (2017) 105:11-20. doi: 10.1016/j. neuint.2017.01.018

448. Zhao T, Wang Q. Capillarisin Protects SH-SY5Y Cells Against BupivacaineInduced Apoptosis via ROS-Mediated PI3K/PKB Pathway. Life Sci (2020) 259:118279. doi: 10.1016/j.lfs.2020.118279

449. Yu Z, Tang L, Chen L, Li J, Wu W, Hu C. Capillarisin Suppresses Lipopolysaccharide-Induced Inflammatory Mediators in BV2 Microglial Cells by Suppressing TLR4-Mediated NF- Kb and MAPKs Signaling Pathway. Neurochem Res (2015) 40:1095-101. doi: 10.1007/s11064-015$1567-4$

450. Kim HK, Choi BR, Bak YO, Zhao C, Lee SW, Jeon JH, et al. The Role of Capillarisin From Artemisia Capillaris on Penile Erection. Phyther Res (2012) 26:800-5. doi: 10.1002/ptr.3635

451. Peng G, Long X. Capillarisin Exerts Antiasthmatic Activity in Neonatal Rats via Modulating the Matrix Remodeling. Pak J Pharm Sci (2020) 33:1907-15. doi: 10.36721/PJPS.2020.33.4.SUP.1907-1915.1

452. Kim M, Chun J, Jung HA, Choi JS, Kim YS. Capillarisin Attenuates ExerciseInduced Muscle Damage Through MAPK and NF- $\mathrm{kb}$ Signaling. Phytomedicine (2017) 32:30-6. doi: 10.1016/j.phymed.2017.04.007

453. Pimpley V, Patil S, Srinivasan K, Desai N, Murthy PS. The Chemistry of Chlorogenic Acid From Green Coffee and Its Role in Attenuation of Obesity 
and Diabetes. Prep Biochem Biotechnol (2020) 50:969-78. doi: 10.1080/ 10826068.2020.1786699

454. Farias-Pereira R, Park CS, Park Y. Mechanisms of Action of Coffee Bioactive Components on Lipid Metabolism. Food Sci Biotechnol (2019) 28:1287-96. doi: 10.1007/s10068-019-00662-0

455. Yamagata K. Do Coffee Polyphenols Have a Preventive Action on Metabolic Syndrome Associated Endothelial Dysfunctions? An Assessment of the Current Evidence. Antioxidants (2018) 7:26. doi: 10.3390/antiox7020026

456. Ali SS, Ahmad WANW, Budin SB, Zainalabidin S. Implication of Dietary Phenolic Acids on Inflammation in Cardiovascular Disease. Rev Cardiovasc Med (2020) 21:225-40. doi: 10.31083/J.RCM.2020.02.49

457. Silva H, Lopes NMF. Cardiovascular Effects of Caffeic Acid and Its Derivatives: A Comprehensive Review. Front Physiol (2020) 11:595516. doi: 10.3389/fphys.2020.595516

458. Li L, Su C, Chen X, Wang Q, Jiao W, Luo H, et al. Chlorogenic Acids in Cardiovascular Disease: A Review of Dietary Consumption, Pharmacology, and Pharmacokinetics. J Agric Food Chem (2020) 68:6464-84. doi: 10.1021/ acs.jafc.0c01554

459. Choi J, Park JK, Lee KT, Park KK, Kim WB, Lee JH, et al. In Vivo Antihepatotoxic Effects of Ligularia Fischeri Var. Spiciformis and the Identification of the Active Component, 3,4-Dicaffeoylquinic Acid. J Med Food (2005) 8:348-52. doi: 10.1089/jmf.2005.8.348

460. Monteiro Espíndola KM, Ferreira RG, Mosquera Narvaez LE, Rocha Silva Rosario AC, Machado Da Silva AH, Bispo Silva AG, et al. Chemical and Pharmacological Aspects of Caffeic Acid and Its Activity in Hepatocarcinoma. Front Oncol (2019) 9:541. doi: 10.3389/fonc.2019.00541

461. Bułdak RJ, Hejmo T, Osowski M, Bułdak Ł, Kukla M, Polaniak R, et al. The Impact of Coffee and Its Selected Bioactive Compounds on the Development and Progression of Colorectal Cancer In Vivo and In Vitro. Molecules (2018) 23:3309. doi: $10.3390 /$ molecules 23123309

462. Liang N, Kitts DD. Role of Chlorogenic Acids in Controlling Oxidative and Inflammatory Stress Conditions. Nutrients (2015) 8(1):16. doi: 10.3390/ nu8010016

463. Kim H, Lee YS. Identification of New Dicaffeoylquinic Acids From Chrysanthemum Morifolium and Their Antioxidant Activities. Planta Med (2005) 71:871-6. doi: 10.1055/s-2005-873115

464. Izuta H, Narahara Y, Shimazawa M, Mishima S, Kondo SI, Hara H. 1,1Diphenyl-2-Picrylhydrazyl Radical Scavenging Activity of Bee Products and Their Constituents Determined by ESR. Biol Pharm Bull (2009) 32:1947-51. doi: $10.1248 / \mathrm{bpb} .32 .1947$

465. Fukutomi R, Ohishi T, Koyama Y, Pervin M, Nakamura Y, Isemura M. Beneficial Effects of Epigallocatechin-3-O-Gallate, Chlorogenic Acid, Resveratrol, and Curcumin on Neurodegenerative Diseases. Molecules (2021) 26:415. doi: 10.3390/molecules26020415

466. Habtemariam S. Protective Effects of Caffeic Acid and the Alzheimer's Brain: An Update. Mini-Rev Med Chem (2016) 17:667-74. doi: 10.2174/ 1389557516666161130100947

467. Socala K, Szopa A, Serefko A, Poleszak E, Wlaz P. Neuroprotective Effects of Coffee Bioactive Compounds: A Review. Int J Mol Sci (2020) 22:1-64. doi: 10.3390/IJMS22010107

468. Khan F, Bamunuarachchi NI, Tabassum N, Kim YM. Caffeic Acid and Its Derivatives: Antimicrobial Drugs Toward Microbial Pathogens. J Agric Food Chem (2021) 69(10):2979-3004. doi: 10.1021/acs.jafc.0c07579

469. Godlewska-żyłkiewicz B, Świsłocka R, Kalinowska M, Golonko A, Świderski G, Arciszewska Ż, et al. Biologically Active Compounds of Plants: StructureRelated Antioxidant, Microbiological and Cytotoxic Activity of Selected Carboxylic Acids. Mater (Basel) (2020) 13:1-37. doi: 10.3390/ma13194454

470. Zhao Y, Geng CA, Ma YB, Huang XY, Chen H, Cao TW, et al. UFLC/MS-ITTOF Guided Isolation of Anti-HBV Active Chlorogenic Acid Analogues From Artemisia Capillaris as a Traditional Chinese Herb for the Treatment of Hepatitis. J Ethnopharmacol (2014) 156:147-54. doi: 10.1016/ j.jep.2014.08.043

471. Yang ZZ, Yu YT, Lin HR, Liao DC, Cui XH, Wang HB. Lonicera Japonica Extends Lifespan and Healthspan in Caenorhabditis Elegans. Free Radic Biol Med (2018) 129:310-22. doi: 10.1016/j.freeradbiomed.2018.09.035

472. Ikeda R, Yanagisawa M, Takahashi N, Kawada T, Kumazawa S, Yamaotsu N, et al. Brazilian Propolis-Derived Components Inhibit TNF- $\alpha$-Mediated Downregulation of Adiponectin Expression via Different Mechanisms in
3T3-L1 Adipocytes. Biochim Biophys Acta - Gen Subj (2011) 1810:695-703. doi: 10.1016/j.bbagen.2011.04.007

473. Kitamura H. Effects of Propolis Extract and Propolis-Derived Compounds on Obesity and Diabetes: Knowledge From Cellular and Animal Models. Molecules (2019) 24(23):4394. doi: 10.3390/molecules24234394

474. Choi S-S, Cha B-Y, Iida K, Lee Y-S, Yonezawa T, Teruya T, et al. Artepillin C, as a Ppar $\gamma$ Ligand, Enhances Adipocyte Differentiation and Glucose Uptake in 3T3-L1 Cells. Biochem Pharmacol (2011) 81:925-33. doi: 10.1016/ J.BCP.2011.01.002

475. Ueda M, Hayashibara K, Ashida H. Propolis Extract Promotes Translocation of Glucose Transporter 4 and Glucose Uptake Through Both PI3K- and AMPK-Dependent Pathways in Skeletal Muscle. BioFactors (2013) 39:45766. doi: 10.1002/biof.1085

476. Nakashima K, Murakami T, Tanabe H, Inoue M. Identification of a Naturally Occurring Retinoid X Receptor Agonist From Brazilian Green Propolis. Biochim Biophys Acta - Gen Subj (2014) 1840:3034-41. doi: 10.1016/ j.bbagen.2014.06.011

477. Umeda M, Hiramoto M, Watanabe A, Tsunoda N, Imai T. Arginine-Induced Insulin Secretion in Endoplasmic Reticulum. Biochem Biophys Res Commun (2015) 466:717-22. doi: 10.1016/j.bbrc.2015.09.006

478. De Oliveira PF, De Souza Lima IM, Munari CC, Bastos JK, Da Silva Filho AA, Tavares DC. Comparative Evaluation of Antiproliferative Effects of Brazilian Green Propolis, Its Main Source Baccharis Dracunculifolia, and Their Major Constituents Artepillin C and Baccharin. Planta Med (2014) 80:490-2. doi: $10.1055 / \mathrm{s}-0034-1368298$

479. Souza RP, Bonfim-Mendonça PS, Damke GMZF, de-Assis Carvalho ARB, Ratti BA, Dembogurski DSO, et al. Artepillin C Induces Selective Oxidative Stress and Inhibits Migration and Invasion in a Comprehensive Panel of Human Cervical Cancer Cell Lines. Anticancer Agents Med Chem (2018) 18:1750-60. doi: 10.2174/1871520618666180604092930

480. Maruta H, Ahn MR. From Bench (Laboratory) to Bed (Hospital/Home): How to Explore Effective Natural and Synthetic PAK1-Blockers/LongevityPromoters for Cancer Therapy. Eur J Med Chem (2017) 142:229-43. doi: 10.1016/j.ejmech.2017.07.043

481. Kumazaki M, Shinohara H, Taniguchi K, Yamada N, Ohta S, Ichihara K, et al. Propolis Cinnamic Acid Derivatives Induce Apoptosis Through Both Extrinsic and Intrinsic Apoptosis Signaling Pathways and Modulate of miRNA Expression. Phytomedicine (2014) 21:1070-7. doi: 10.1016/ j.phymed.2014.04.006

482. Chiu H-F, Han Y-C, Shen Y-C, Golovinskaia O, Venkatakrishnan K, Wang $\mathrm{C}-\mathrm{K}$. Chemopreventive and Chemotherapeutic Effect of Propolis and Its Constituents: A Mini-Review. J Cancer Prev (2020) 25:70-8. doi: 10.15430/ jcp.2020.25.2.70

483. Mishima S, Ono Y, Araki Y, Akao Y, Nozawa Y. Two Related Cinnamic Acid Derivatives From Brazilian Honey Bee Propolis, Baccharin and Drupanin, Induce Growth Inhibition in Allografted Sarcoma S-180 in Mice. Biol Pharm Bull (2005) 28:1025-30. doi: 10.1248/bpb.28.1025

484. Akao Y, Maruyama H, Matsumoto K, Ohguchi K, Nishizawa K, Sakamoto T, et al. Cell Growth Inhibitory Effect of Cinnamic Acid Derivatives From Propolis on Human Tumor Cell Lines. Biol Pharm Bull (2003) 26:1057-9. doi: $10.1248 / \mathrm{bpb} .26 .1057$

485. Ahn MR, Kunimasa K, Ohta T, Kumazawa S, Kamihira M, Kaji K, et al. Suppression of Tumor-Induced Angiogenesis by Brazilian Propolis: Major Component Artepillin C Inhibits In Vitro Tube Formation and Endothelial Cell Proliferation. Cancer Lett (2007) 252:235-43. doi: 10.1016/ j.canlet.2006.12.039

486. Paulino N, Abreu SRL, Uto Y, Koyama D, Nagasawa H, Hori H, et al. AntiInflammatory Effects of a Bioavailable Compound, Artepillin C, in Brazilian Propolis. Eur J Pharmacol (2008) 587:296-301. doi: 10.1016/ j.ejphar.2008.02.067

487. Shimizu K, Ashida H, Matsuura Y, Kanazawa K. Antioxidative Bioavailability of Artepillin C in Brazilian Propolis. Arch Biochem Biophys (2004) 424:181-8. doi: 10.1016/j.abb.2004.02.021

488. Costa P, Almeida MO, Lemos M, Arruda C, Casoti R, Somensi LB, et al. Artepillin C, Drupanin, Aromadendrin-4'-O-Methyl-Ether and Kaempferide From Brazilian Green Propolis Promote Gastroprotective Action by Diversified Mode of Action. J Ethnopharmacol (2018) 226:82-9. doi: 10.1016/j.jep.2018.08.006 
489. Shimizu Y, Suzuki T. Brazilian Propolis Extract Reduces Intestinal Barrier Defects and Inflammation in a Colitic Mouse Model. Nutr Res (2019) 69:3041. doi: $10.1016 /$ j.nutres.2019.07.003

490. de Oliveira Dembogurski DS, Silva Trentin D, Boaretto AG, Rigo GV, da Silva RC, Tasca T, et al. Brown Propolis-Metabolomic Innovative Approach to Determine Compounds Capable of Killing Staphylococcus Aureus Biofilm and Trichomonas Vaginalis. Food Res Int (2018) 111:661-73. doi: 10.1016/ j.foodres.2018.05.033

491. Przybyłek I, Karpiński TM. Antibacterial Properties of Propolis. Mol (2019) 24:2047. doi: 10.3390/MOLECULES24112047

492. Takeda K, Nagamatsu K, Okumura K. A Water-Soluble Derivative of Propolis Augments the Cytotoxic Activity of Natural Killer Cells. J Ethnopharmacol (2018) 218:51-8. doi: 10.1016/j.jep.2018.02.035

493. Yanase S, Luo Y, Maruta H. PAK1-Deficiency/Down-Regulation Reduces Brood Size, Activates HSP16.2 Gene and Extends Lifespan in Caenorhabditis Elegans. Drug Discov Ther (2013) 7:29-35. doi: 10.5582/ddt.2013.v7.1.29

494. Hattori H, Okuda K, Murase T, Shigetsura Y, Narise K, Semenza GL, et al. Isolation, Identification, and Biological Evaluation of HIF-1-Modulating Compounds From Brazilian Green Propolis. Bioorg Med Chem (2011) 19:5392-401. doi: 10.1016/j.bmc.2011.07.060

495. Corbett JT. The Scopoletin Assay for Hydrogen Peroxide A Review and a Better Method. J Biochem Biophys Methods (1989) 18:297-307. doi: 10.1016/ 0165-022X(89)90039-0

496. Andreae WA. A Sensitive Method for the Estimation of Hydrogen Peroxide in Biological Materials [9]. Nature (1955) 175:859-60. doi: 10.1038/175859a0

497. Marquez LA, Dunford HB. Transient and Steady-State Kinetics of the Oxidation of Scopoletin by Horseradish Peroxidase Compounds I, II and III in the Presence of NADH. Eur J Biochem (1995) 233:364-71. doi: 10.1111/ j.1432-1033.1995.364_1.x

498. Boveris A, Martino E, Stoppani AOM. Evaluation of the Horseradish Peroxidase-Scopoletin Method for the Measurement of Hydrogen Peroxide Formation in Biological Systems. Anal Biochem (1977) 80:145-58. doi: 10.1016/0003-2697(77)90634-0

499. Lee BC, Lee SY, Lee HJ, Sim GS, Kim JH, Kim JH, et al. Anti-Oxidative and Photo-Protective Effects of Coumarins Isolated From Fraxinus Chinensis. Arch Pharm Res (2007) 30:1293-301. doi: 10.1007/BF02980270

500. Cobley JN, Fiorello ML, Bailey DM. 13 Reasons Why the Brain Is Susceptible to Oxidative Stress. Redox Biol (2018) 15:490-503. doi: 10.1016/ j.redox.2018.01.008

501. Halvorsen B, Brude I, Drevon CA, Nysom J, Ose L, Christiansen EN, et al. Effect of Homocysteine on Copper Ion-Catalyzed, Azo Compound-Initiated, and Mononuclear Cell-Mediated Oxidative Modification of Low Density Lipoprotein. J Lipid Res (1996) 37:1591-600. doi: 10.1016/s0022-2275(20) 39141-0

502. Ogihara H, Ogihara T, Miki M, Yasuda H, Mino M. Plasma Copper and Antioxidant Status in Wilson's Disease. Pediatr Res (1995) 37:219-26. doi: 10.1203/00006450-199502000-00016

503. Bush AI, Goldstein LE. Specific Metal-Catalysed Protein Oxidation Reactions in Chronic Degenerative Disorders of Ageing: Focus on Alzheimer's Disease and Age-Related Cataracts. Novartis Found Symp (2001) 235:26-43. doi: 10.1002/0470868694.ch4

504. Furuhashi M. New Insights Into Purine Metabolism in Metabolic Diseases: Role of Xanthine Oxidoreductase Activity. Am J Physiol - Endocrinol Metab (2020) 319:E827-34. doi: 10.1152/AJPENDO.00378.2020

505. Glantzounis G, Tsimoyiannis E, Kappas A, Galaris D. Uric Acid and Oxidative Stress. Curr Pharm Des (2005) 11:4145-51. doi: 10.2174/ 138161205774913255

506. Chang WS, Chiang HC. Structure-Activity Relationship of Coumarins in Xanthine Oxidase Inhibition. Anticancer Res (1995) 15:1969-73.

507. Kushiyama A, Nakatsu Y, Matsunaga Y, Yamamotoya T, Mori K, Ueda K, et al. Role of Uric Acid Metabolism-Related Inflammation in the Pathogenesis of Metabolic Syndrome Components Such as Atherosclerosis and Nonalcoholic Steatohepatitis. Mediators Inflamm (2016) 2016:8603164. doi: 10.1155/2016/8603164

508. Okuyama T, Shirakawa J, Nakamura T, Murase T, Miyashita D, Inoue R, et al. Association of the Plasma Xanthine Oxidoreductase Activity With the Metabolic Parameters and Vascular Complications in Patients With Type 2 Diabetes. Sci Rep (2021) 11:3768. doi: 10.1038/s41598-021-83234-9
509. Miyata Y, Tanaka H, Shimada A, Sato T, Ito A, Yamanouchi T, et al. Regulation of Adipocytokine Secretion and Adipocyte Hypertrophy by Polymethoxyflavonoids, Nobiletin and Tangeretin. Life Sci (2011) 88:613-8. doi: 10.1016/j.lfs.2011.01.024

510. Ardenghi JV, Pretto JB, Souza MM, Junior AC, Soldi C, Pizzolatti MG, et al. Antinociceptive Properties of Coumarins, Steroid and Dihydrostyryl-2Pyrones From Polygala Sabulosa (Polygalaceae) in Mice. J Pharm Pharmacol (2010) 58:107-12. doi: 10.1211/jpp.58.1.0013

511. Luo C, Xu X, Wei X, Feng W, Huang H, Liu H, et al. Natural Medicines for the Treatment of Fatigue: Bioactive Components, Pharmacology, and Mechanisms. Pharmacol Res (2019) 148:104409. doi: 10.1016/ j.phrs.2019.104409

512. Mogana R, Adhikari A, Debnath S, Hazra S, Hazra B, Teng-Jin K, et al. The Antiacetylcholinesterase and Antileishmanial Activities of Canarium Patentinervium Miq. BioMed Res Int (2014) 2014:903529. doi: 10.1155/ 2014/903529

513. Mula M, Pini S, Cassano GB. The Role of Anticonvulsant Drugs in Anxiety Disorders: A Critical Review of the Evidence. J Clin Psychopharmacol (2007) 27:263-72. doi: $10.1097 /$ jcp.0b013e318059361a

514. Jang JH, Park JE, Han JS. Scopoletin Increases Glucose Uptake Through Activation of PI3K and AMPK Signaling Pathway and Improves Insulin Sensitivity in 3T3-L1 Cells. Nutr Res (2020) 74:52-61. doi: 10.1016/ j.nutres.2019.12.003

515. Huang W, Wen Z, Wang M, Xu B, Zhou B, Li X. Anticomplement and Antitussive Activities of Major Compound Extracted From Chimonanthus Nitens Oliv. Leaf. BioMed Chromatogr (2020) 34(2):e4736. doi: 10.1002/ bmc. 4736

516. Cereijo R, Gavaldà-Navarro A, Cairó M, Quesada-López T, Villarroya J, Morón-Ros S, et al. CXCL14, a Brown Adipokine That Mediates Brown-FatTo-Macrophage Communication in Thermogenic Adaptation. Cell Metab (2018) 28:750-63.e6. doi: 10.1016/j.cmet.2018.07.015

517. Yang IJ, Lee DU, Shin HM. Anti-Inflammatory and Antioxidant Effects of Coumarins Isolated From Foeniculum Vulgare in LipopolysaccharideStimulated Macrophages and 12-O-Tetradecanoylphorbol-13-AcetateStimulated Mice. Immunopharmacol Immunotoxicol (2015) 37:308-17. doi: 10.3109/08923973.2015.1038751

518. Leema G, Tamizhselvi R. Protective Effect of Scopoletin Against CeruleinInduced Acute Pancreatitis and Associated Lung Injury in Mice. Pancreas (2018) 47:577-85. doi: 10.1097/MPA.0000000000001034

519. Liang C, Ju W, Pei S, Tang Y, Xiao Y. Pharmacological Activities and Synthesis of Esculetin and Its Derivatives: A Mini-Review. J Lipid Res (2017) 58:519-28. doi: 10.3390/molecules22030387

520. Oh SY, Kim YH, Kang MK, Lee EJ, Kim DY, Oh H, et al. Aesculetin Attenuates Alveolar Injury and Fibrosis Induced by Close Contact of Alveolar Epithelial Cells With Blood-Derived Macrophages via Il-8 Signaling. Int J Mol Sci (2020) 21:1-17. doi: 10.3390/ijms21155518

521. Singh L, Kaur A, Garg S, Singh AP, Bhatti R. Protective Effect of Esculetin, Natural Coumarin in Mice Model of Fibromyalgia: Targeting ProInflammatory Cytokines and MAO-A. Neurochem Res (2020) 45:2364-74. doi: 10.1007/s11064-020-03095-y

522. Pruccoli L, Morroni F, Sita G, Hrelia P, Tarozzi A. Esculetin as a Bifunctional Antioxidant Prevents and Counteracts the Oxidative Stress and Neuronal Death Induced by Amyloid Protein in Sh-Sy5y Cells. Antioxidants (2020) 9:1-16. doi: 10.3390/antiox9060551

523. Chen Y, Zhang Q, Liu H, Lu C, Liang CL, Qiu F, et al. Esculetin Ameliorates Psoriasis-Like Skin Disease in Mice by Inducing CD4+Foxp3+ Regulatory T Cells. Front Immunol (2018) 9:2092. doi: 10.3389/fimmu.2018.02092

524. Kim AD, Madduma Hewage SRK, Piao MJ, Kang KA, Cho SJ, Hyun JW. Esculetin Induces Apoptosis in Human Colon Cancer Cells by Inducing Endoplasmic Reticulum Stress. Cell Biochem Funct (2015) 33:487-94. doi: $10.1002 / \mathrm{cbf} .3146$

525. Choi YJ, Lee CM, Park SH, Nam MJ. Esculetin Induces Cell Cycle Arrest and Apoptosis in Human Colon Cancer LoVo Cells. Environ Toxicol (2019) 34:1129-36. doi: 10.1002/tox.22815

526. Kim YR, Park BK, Kim YH, Shim I, Kang IC, Lee MY. Antidepressant Effect of Fraxinus Rhynchophylla Hance Extract in a Mouse Model of Chronic Stress-Induced Depression. BioMed Res Int (2018) 2018:8249563. doi: $10.1155 / 2018 / 8249563$ 
527. Nakano M, Imamura H, Sasaoka N, Yamamoto M, Uemura N, Shudo T, et al. ATP Maintenance via Two Types of ATP Regulators Mitigates Pathological Phenotypes in Mouse Models of Parkinson's Disease. EBioMedicine (2017) 22:225-41. doi: 10.1016/j.ebiom.2017.07.024

528. Xu W, Wang J, Ju B, Lan X, Ying X, Stien D. Seven Compounds From Portulaca Oleracea L. And Their Anticholinesterase Activities. Nat Prod Res (2021) 30:1-7. doi: 10.1080/14786419.2021.1916928

529. Liu YL, Ho DK, Cassady JM, Cook VM, Baird WM. Isolation of Potential Cancer Chemopreventive Agents From Eriodictyon Californicum. $J$ Nat Prod (1992) 55:357-63. doi: 10.1021/np50081a012

530. Mirzahosseini G, Manayi A, Khanavi M, Safavi M, Salari A, Madjid Ansari A, et al. Bio-Guided Isolation of Centaurea Bruguierana Subsp. Belangerana Cytotoxic Components. Nat Prod Res (2019) 33:1687-90. doi: 10.1080/ 14786419.2018 .1428590

531. Sen A, Turan SO, Bitis L. Bioactivity-Guided Isolation of Anti-Proliferative Compounds From Endemic Centaurea Kilaea. Pharm Biol (2016) 55:541-6. doi: 10.1080/13880209.2016.1255980

532. Yeon Park J, Young Kim H, Shibamoto T, Su Jang T, Cheon Lee S, Suk Shim J, et al. Beneficial Effects of a Medicinal Herb, Cirsium Japonicum Var. Maackii, Extract and Its Major Component, Cirsimaritin on Breast Cancer Metastasis in MDA-MB-231 Breast Cancer Cells. Bioorg Med Chem Lett (2017) 27:3968-73. doi: 10.1016/j.bmcl.2017.07.070

533. Pathak G, Singh S, Kumari P, Raza W, Hussain Y, Meena A. Cirsimaritin, a Lung Squamous Carcinoma Cells (NCIH-520) Proliferation Inhibitor. J Biomol Struct Dyn (2021) 39:3312-23. doi: 10.1080/07391102.2020.1763198

534. Quan Z, Gu J, Dong P, Lu J, Wu X, Wu W, et al. Reactive Oxygen SpeciesMediated Endoplasmic Reticulum Stress and Mitochondrial Dysfunction Contribute to Cirsimaritin-Induced Apoptosis in Human Gallbladder Carcinoma GBC-SD Cells. Cancer Lett (2010) 295:252-9. doi: 10.1016/ j.canlet.2010.03.008

535. Xu JH, Lo YM, Chang WC, Huang DW, Wu JSB, Jhang YY, et al. Identification of Bioactive Components From Ruellia Tuberosa L. On Improving Glucose Uptake in TNF- $\alpha$-Induced Insulin-Resistant Mouse FL83B Hepatocytes. Evidence-Based Complement Altern Med (2020) 2020:6644253. doi: 10.1155/2020/6644253

536. Bower AM, Real Hernandez LM, Berhow MA, De Mejia EG. Bioactive Compounds From Culinary Herbs Inhibit a Molecular Target for Type 2 Diabetes Management, Dipeptidyl Peptidase IV. J Agric Food Chem (2014) 62:6147-58. doi: 10.1021/jf500639f

537. Lee D, Kim KH, Lee J, Hwang GS, Lee HL, Hahm DH, et al. Protective Effect of Cirsimaritin Against Streptozotocin-Induced Apoptosis in Pancreatic Beta Cells. J Pharm Pharmacol (2017) 69:875-83. doi: 10.1111/jphp.12719

538. Kelm MA, Nair MG, Strasburg GM, DeWitt DL. Antioxidant and Cyclooxygenase Inhibitory Phenolic Compounds From Ocimum Sanctum Linn. Phytomedicine (2000) 7:7-13. doi: 10.1016/S0944-7113(00)80015-X

539. Ben Sghaier M, Skandrani I, Nasr N, Franca MGD, Chekir-Ghedira L, Ghedira K. Flavonoids and Sesquiterpenes From Tecurium Ramosissimum Promote Antiproliferation of Human Cancer Cells and Enhance Antioxidant Activity: A Structure-Activity Relationship Study. Environ Toxicol Pharmacol (2011) 32:336-48. doi: 10.1016/j.etap.2011.07.003

540. Shin MS, Park JY, Lee J, Yoo HH, Hahm DH, Lee SC, et al. AntiInflammatory Effects and Corresponding Mechanisms of Cirsimaritin Extracted From Cirsium Japonicum Var. Maackii Maxim. Bioorg Med Chem Lett (2017) 27:3076-80. doi: 10.1016/j.bmcl.2017.05.051

541. Miski M, Ulubelen A, Johansson C, Mabry TJ. Antibacterial Activity Studies of Flavonoids From Salvia Palaestina. J Nat Prod (1983) 46:874-5. doi: 10.1021/np50030a007

542. Quintanilla-Licea R, Vargas-Villarreal J, Verde-Star MJ, Rivas-Galindo VM, Torres-Hernández ÁD. Antiprotozoal Activity Against Entamoeba Histolytica of Flavonoids Isolated From Lippia Graveolens Kunth. Molecules (2020) 25:2464. doi: 10.3390/molecules25112464

543. Yan H, Wang H, Ma L, Ma X, Yin J, Wu S, et al. Cirsimaritin Inhibits Influenza A Virus Replication by Downregulating the NF-kb Signal Transduction Pathway. Virol J (2018) 15:1-9. doi: 10.1186/s12985-018-0995-6

544. Kavvadias D, Monschein V, Sand P, Riederer P, Schreier P. Constituents of Sage (Salvia Officinalis) With In Vitro Affinity to Human Brain Benzodiazepine Receptor. Planta Med (2003) 69:113-7. doi: 10.1055/s2003-37712
545. González-Trujano ME, Hernández-Sánchez LY, Ocotero VM, DorazcoGonzález A, Fefer PG, Aguirre-Hernández E. Pharmacological Evaluation of the Anxiolytic-Like Effects of Lippia Graveolens and Bioactive Compounds. Pharm Biol (2017) 55:1569-76. doi: 10.1080/13880209.2017.1310908

546. Abdelhalim A, Karim N, Chebib M, Aburjai T, Khan I, Johnston GAR, et al. Antidepressant, Anxiolytic and Antinociceptive Activities of Constituents From Rosmarinus Officinalis. J Pharm Pharm Sci (2015) 18:448-59. doi: 10.18433/j3pw38

547. Amakura Y, Yoshimura M, Takaoka M, Toda H, Tsutsumi T, Matsuda R, et al. Characterization of Natural Aryl Hydrocarbon Receptor Agonists From Cassia Seed and Rosemary. Molecules (2014) 19:4956-66. doi: 10.3390/ molecules 19044956

548. Wang JP, Chang LC, Hsu MF, Chen SC, Kuo SC. Inhibition of FormylMethionyl-Leucyl-Phenylalanine-Stimulated Respiratory Burst by Cirsimaritin Involves Inhibition of Phospholipase D Signaling in Rat Neutrophils. Naunyn Schmiedebergs Arch Pharmacol (2002) 366:307-14. doi: 10.1007/s00210-002-0631-1

549. Yokozawa T, Dong E, Kawai Y, Gemba M, Shimizu M. Protective Effects of Some Flavonoids on the Renal Cellular Membrane. Exp Toxicol Pathol (1999) 51:9-14. doi: 10.1016/S0940-2993(99)80050-5

550. Hasrat JA, De Bruyne T, De Backer JP, Vauquelin G, Vlietinck AJ. Cirsimarin and Cirsimaritin, Flavonoids of Microtea Debilis (Phytolaccaceae) With Adenosine Antagonistic Properties in Rats: Leads for New Therapeutics in Acute Renal Failure. J Pharm Pharmacol (1997) 49:1150-6. doi: 10.1111/j.2042-7158.1997.tb06059.x

551. Lee TY, Chen FY, Chang HH, Lin HC. The Effect of Capillarisin on Glycochenodeoxycholic Acid-Induced Apoptosis and Heme Oxygenase-1 in Rat Primary Hepatocytes. Mol Cell Biochem (2009) 325:53-9. doi: 10.1007/s11010-008-0019-8

552. Lee SO, Jeong YJ, Kim M, Kim CH, Lee IS. Suppression of PMA-Induced Tumor Cell Invasion by Capillarisin via the Inhibition of NF-kb-Dependent MMP-9 Expression. Biochem Biophys Res Commun (2008) 366:1019-24. doi: 10.1016/j.bbrc.2007.12.068

553. Bastos JK, De Sousa JPB, Leite MF, Jorge RF, Resende DO, Da Silva Filho AA, et al. Seasonality Role on the Phenolics From Cultivated Baccharis Dracunculifolia. Evidence-Based Complement Altern Med (2011) 2011:464289. doi: 10.1093/ecam/nep077

554. Jorge R, Furtado NAJC, Sousa JPB, Da Silva Filho AA, Gregório Junior LE, Martins CHG, et al. Brazilian Propolis: Seasonal Variation of the Prenylated P-Coumaric Acids and Antimicrobial Activity. Pharm Biol (2008) 46:88993. doi: $10.1080 / 13880200802370373$

555. Carrão DB, De Albuquerque NCP, Marques LMM, Crotti AEM, Pilon AC, Bolzani VDS, et al. In Vitro Metabolism of Artepillin C by Rat and Human Liver Microsomes. Planta Med (2017) 83:737-45. doi: 10.1055/s-0042-124359

556. Boudreau A, Poulev A, Ribnicky DM, Raskin I, Rathinasabapathy T, Richard AJ, et al. Distinct Fractions of an Artemisia Scoparia Extract Contain Compounds With Novel Adipogenic Bioactivity. Front Nutr (2019) 6:18. doi: 10.3389/fnut.2019.00018

557. Ribnicky D, Kim SB, Poulev A, Wang Y, Boudreau A, Raskin I, et al. Prenylated Coumaric Acids From Artemisia Scoparia Beneficially Modulate Adipogenesis. J Nat Prod (2021) 84(4):1078-86. doi: 10.1021/acs.jnatprod.0c01149

558. Lin S, Xiao YQ, Zhang QW, Shi JG, Wang ZM. Studies on Chemical Constituents in Bud of Artemisia Scoparia (III). Zhongguo Zhongyao Zazhi (2004) 29:431.

559. Okuno I, Uchida K, Nakamura M, Sakurawi K. Studies on Choleretic Constituents in Artemisia Capillaris Thunb. Chem Pharm Bull (1988) 36:769-75. doi: 10.1248/cpb.36.769

560. Kitagawa I, Fukuda Y, Yoshihara M, Yamahara J, Yoshikawa M. Capillartemisin A and B, Two New Choleretic Principles From Artemisiae Capillaris Herba. Chem Pharm Bull (1983) 31:352-5. doi: 10.1248/ cpb. 31.352

561. Washio K, Shimamoto Y, Kitamura H. Brazilian Propolis Extract Increases Leptin Expression in Mouse Adipocytes. BioMed Res (2015) 36:343-6. doi: $10.2220 /$ biomedres. 36.343

562. Iio A, Ohguchi K, Inoue H, Maruyama H, Araki Y, Nozawa Y, et al. Ethanolic Extracts of Brazilian Red Propolis Promote Adipocyte Differentiation Through Ppary Activation. Phytomedicine (2010) 17:974-9. doi: 10.1016/ j.phymed.2010.03.001 
563. Kitamura H, Naoe Y, Kimura S, Miyamoto T, Okamoto S, Toda C, et al. Beneficial Effects of Brazilian Propolis on Type 2 Diabetes in $\mathrm{Ob} / \mathrm{Ob}$ Mice. Adipocyte (2013) 2:227-36. doi: 10.4161/adip.25608

564. Munakata R, Takemura T, Tatsumi K, Moriyoshi E, Yanagihara K, Sugiyama A, et al. Isolation of Artemisia Capillaris Membrane-Bound DiPrenyltransferase for Phenylpropanoids and Redesign of Artepillin C in Yeast. Commun Biol (2019) 2:384. doi: 10.1038/s42003-019-0630-0

565. Clarke TC, Black LI, Stussman BJ, Barnes PM, Nahin RL. Trends in the Use of Complementary Health Approaches Among Adults: United States, 20022012. Natl Health Stat Rep (2015) (79):1-16.

566. Britton ER, Kellogg JJ, Kvalheim OM, Cech NB. Biochemometrics to Identify Synergists and Additives From Botanical Medicines: A Case Study With Hydrastis Canadensis (Goldenseal). J Nat Prod (2018) 81:484-93. doi: 10.1021/acs.jnatprod.7b00654

567. Sorkin BC, Kuszak AJ, Bloss G, Fukagawa NK, Hoffman FA, Jafari M, et al. Improving Natural Product Research Translation: From Source to Clinical Trial. FASEB J (2020) 34:41-65. doi: 10.1096/fj.201902143R

568. Logendra S, Ribnicky DM, Yang H, Poulev A, Ma J, Kennelly EJ, et al. Bioassay-Guided Isolation of Aldose Reductase Inhibitors From Artemisia Dracunculus. Phytochemistry (2006) 67:1539-46. doi: 10.1016/ j.phytochem.2006.05.015

569. Eisenman SW, Poulev A, Struwe L, Raskin I, Ribnicky DM. Qualitative Variation of Anti-Diabetic Compounds in Different Tarragon (Artemisia
Dracunculus L.) Cytotypes. Fitoterapia (2011) 82:1062-74. doi: 10.1016/ j.fitote.2011.07.003

570. Baell JB. Feeling Nature's PAINS: Natural Products, Natural Product Drugs, and Pan Assay Interference Compounds (PAINS). J Nat Prod (2016) 79:61628. doi: 10.1021/acs.jnatprod.5b00947

Conflict of Interest: The authors declare that the research was conducted in the absence of any commercial or financial relationships that could be construed as a potential conflict of interest.

Publisher's Note: All claims expressed in this article are solely those of the authors and do not necessarily represent those of their affiliated organizations, or those of the publisher, the editors and the reviewers. Any product that may be evaluated in this article, or claim that may be made by its manufacturer, is not guaranteed or endorsed by the publisher.

Copyright $\odot 2021$ Boudreau, Richard, Harvey and Stephens. This is an open-access article distributed under the terms of the Creative Commons Attribution License (CC BY). The use, distribution or reproduction in other forums is permitted, provided the original author(s) and the copyright owner(s) are credited and that the original publication in this journal is cited, in accordance with accepted academic practice. No use, distribution or reproduction is permitted which does not comply with these terms. 